UNIVERSIDADE DE SÃO PAULO

INSTITUTO DE PSICOLOGIA

JOÃO VICTOR DE SOUZA REIS

Onde está o pai? O lugar do homem em famílias "matrifocais" pobres na cidade de São Paulo

SÃO PAULO

2014 


\title{
Onde está o pai? O lugar do homem em famílias "matrifocais" pobres na cidade de São Paulo
}

\author{
(Versão Original)
}

Dissertação apresentada ao Instituto de Psicologia da Universidade de São Paulo como parte dos requisitos para obtenção do título de Mestre em Psicologia.

Área de Concentração: Psicologia Social.

Orientadora: Prof ${ }^{a}$ Associada Belinda Piltcher Haber Mandelbaum.

SÃO PAULO

2014 
Reis, João Victor de Souza.

Onde está o pai? O lugar do homem em famílias "matrifocais" pobres na cidade de São Paulo / João Victor de Souza Reis; orientadora Belinda P. H. Mandelbaum. -- São Paulo, 2014.

$109 \mathrm{f}$.

Dissertação (Mestrado - Programa de Pós-Graduação em Psicologia. Área de Concentração: Psicologia Social) - Instituto de Psicologia da Universidade de São Paulo.

1. Família 2. Famílias matrifocais 3. Lugar do homem 4. Adolescente em conflito com a lei 5. Famílias pobres I. Título.

$$
\text { HQ10 }
$$


Nome: Reis, João Victor de Souza

Título: Onde está o pai? O lugar do homem em famílias "matrifocais" pobres na cidade de São Paulo.

Dissertação apresentada ao Instituto de Psicologia da Universidade de São Paulo como parte dos requisitos para obtenção do título de Mestre em Psicologia.

Aprovado em:

Banca Examinadora

Profa. Dra.

Instituição: Assinatura:

Profa. Dra.

Instituição: Assinatura:

Profa. Dra.

Instituição: Assinatura: 
Para meus pais, Cleide e Haroldo e à minha irmã, Ana Cláudia

Para os meninos do MSE - Campo Limpo e suas famílias 


\section{AGRADECIMENTOS}

À Coordenação de Aperfeiçoamento de Pessoal de Nível Superior (CAPES), pela bolsa de mestrado, uma das condições de possibilidade da realização desta pesquisa.

À Professora Belinda Piltcher Haber Mandelbaum, pela confiança, paciência e orientação durante todo o percurso deste trabalho.

Aos companheiros de orientação Péricles Pinheiro, Márcio Dionízio, Fernanda Rodrigues, Luíz de Santi. Ao Luís Saraiva, à Lia Schucman e à Joyce Rezende, para além das enormes contribuições ao texto, de colegas tornaram-se grandes amigos, parceiros de risadas, confissões e ideais.

À Nalva, à Rose e à Selma, pela eficiência no trabalho junto à secretaria do PST e por sempre me tratarem de forma especial.

À Lívia Gaetani, à Alice Reis, ao Lucas Gordon e ao José Henrique Palumbo, pela amizade e por me mostrar que não estou só em pensar a vida e a sociedade de maneira diferente.

Ao Fábio Carezzato, ao Pedro Seinchman e ao André Solnik, amigos e companheiros, por dividirem o mesmo teto e por me aguentar monotemático durante todos esses longos meses.

Ao Alan Osmo, ao Vitor Barão, ao Márcio Bandeira e ao Christian Haritçalde, grandes amigos, por dividir e compartilhar as alegrias e angústias que somente um mestrado pode trazer.

Aos irmãos que não tive. Paulo Cabral (Tony), Lucas Bullara (Tierry) e Danilo Faizibaioff (Dan), por me ensinarem o significado da palavra "amizade".

Ao colegas do MSE - Campo Limpo. À Vanessa Bastos, ao Jorge Franco, à Ana Cláudia Vasconcelos, à Lídia Carneiro, à Joyce Carmo, ao Sérgio Roberto, à Ana Vitória Abati, à Patrícia Andrade, ao Rodrigo da Silva, ao Leonardo Vidal, à Lucinda Rodrigues e à Ivone. Pelo carinho, respeito e parceria; pelas cervejas e por me ensinarem muito mais do que qualquer universidade me ensinaria. 
À minha avó Perolina, ao meu tio Marcos, às minhas tias Eliane e Daniela, ao meu cunhado Eli, às minhas primas Ana Flávia, Natália, Sophia e Ana Laura. Minha família, meu porto seguro. Pelo amor e carinho, por sempre lembrar minhas origens, quem sou, dando-me força e coragem, régua e compasso para alcançar tudo que posso ser.

À minha irmã Ana Cláudia de Castro e Reis, antes de tudo, pelo amor incondicional. Tendo somente um ao outro e os ensinamentos de nossos pais, viemos para São Paulo ainda adolescentes, hoje nos tornamos adultos, e ela uma mulher da qual tenho orgulho sem igual.

À minha mãe Cleide Pereira de Castro e Reis, mulher forte, guerreira e sábia. Ao meu pai Haroldo de Souza Reis, por sua lealdade, caráter e coração. À ambos, pelo amor e por tudo. Pelo incansável apoio às minhas escolhas, por estarem ao meu lado desde meus primeiros passos até hoje, e sempre. Por me mostrar a cada dia serem pessoas muito maiores do que eu poderia imaginar. 


\section{RESUMO}

REIS, João Victor de Souza. Onde está o pai? O lugar do homem em famílias "matrifocais" pobres na cidade de São Paulo. 2014. 109f. Dissertação (Mestrado em Psicologia) - Instituto de Psicologia, Universidade de São Paulo, São Paulo, 2014.

A presente dissertação consiste em investigar a produção de sentidos a respeito do lugar do homem em famílias "matrifocais" na cidade de São Paulo. O contexto da pesquisa está baseado em minha experiência no trabalho como técnico do serviço de Medidas Socioeducativa em meio aberto (MSEMA) na região de Campo Limpo, zona sul de São Paulo, entre o início do ano de 2012 e o início de 2013. Esse serviço é designado a jovens de 12 a 18 anos incompletos que estão em situação de conflito com a lei. Como técnico fui responsável pelo acompanhamento de muitos adolescentes em processo de medida socioeducativa - Liberdade Assistida e Prestação de Serviço à Comunidade que contava com atendimentos individuais, familiares e atividades que envolviam o entorno social. A partir da noção de "campo-tema" cunhada por Peter K. Spink (2003), em que o campo não se limita ao âmbito espacial, mas a toda processualidade de temas que a ele está referido, utilizou-se um método em que o pesquisador se volta aos lugares e às micro relações ali existentes. Para tanto, fiz recortes em minha vivência para realizar estudos de casos e descrever cenas a fim de estabelecer possíveis ligações teóricas que puderam me ajudar a compreender os sentidos produzidos pelos familiares sobre o lugar dos homens dentro de diferentes dinâmicas familiares. Verificamos como a figura paterna encontra-se frequentemente nesse contexto: pouco conhecida (em sua história de vida e características pessoais), enfraquecida (por sua pouca influência familiar) e ausente (fisicamente). Em famílias monoparentais de chefia feminina em que está presente o filho homem, aqui estudadas, observou-se que esse se posiciona, e é posicionado, de maneira a executar funções consideradas tradicionais do "homem da casa" como o provimento econômico, de proteção e respeito, no entanto, a autoridade familiar é transferida para as mulheres da casa, em especial à mãe. O lugar do homem é afetado pelo da mulher que cada vez mais angaria certa autonomia pela crescente entrada no mercado de trabalho e, como nos casos apresentados, pelo acesso a programas de transferência de renda, especificamente, o Bolsa Família. Acumulam-se responsabilidades familiares pelas mulheres que sob a insígnia de "fortes" desempenham múltiplas funções, todavia, desgastam-se física e emocionalmente, enquanto os homens encontra-se, de maneira geral, desresponsabilizados.

Palavras-chave: Família; Família matrifocal; Lugar do homem; Adolescente em conflito com a lei; Famílias pobres. 


\begin{abstract}
REIS, João Victor de Souza. Where is the father? The place of men in poor "matrifocal" families in São Paulo. 2014. 109f. Dissertation (Masters in Psychology) - Instituto de Psicologia, Universidade de São Paulo, São Paulo, 2014.

This dissertation investigates the existing production of meanings that there are about the man's place in "matrifocal" families in São Paulo. The context of the research is based on my experience working as a Socio-Educative Measures Technician in open environment (MSE-MA) in the region of Campo Limpo, in the southern part of São Paulo, between early 2012 and early 2013. This service is designed for young people between 12 and 18 years old in situations of conflict with the law. As a coach I was responsible for monitoring many teenagers under socio-educative measurements - Assisted Freedom and Community Service - which included individual sessions, sessions with the family, and activities involving their social environment. The research theme emerged from this field. From the "theme-field" notion coined by Peter K. Spink (2003), where the field is not limited to the spatial domain, but the whole processuality of themes it refers to, a method where the researcher turns their attention to the places and micro relations therein, was used. For that purpose, I selected parts from my work experience from which to conduct case studies and describe scenes in order to establish possible theoretical links that helped me understand the meanings produced by the family members about the place of men within different family dynamics. We noticed how the father figure often appears in this context: little known (life history and personal characteristics), weakened (has little family influence) and absent (physically). In single-parent families with female leadership where a son is present, the latter places himself, and is positioned, to perform the functions considered traditional for the "man of the house", such as economic provision, protection and respect, however, the family authority is transferred to the women of the house, especially to the mother. The man's place is affected by the woman's, who has increasingly more autonomy caused by growing participation in the labor market and, as happened in the cases presented, access to income transfer programs such as Bolsa Família (a Brazilian welfare program). Family responsibilities are accumulated by women who, fitting under the banner of "strong", develop multiple roles. However they become physically and emotionally worn out, while men are, in general, not held accountable.
\end{abstract}

Keywords: Family; Matrifocal family; Man's place; Adolescents in conflict with the law; Poor families. 


\section{SUMÁRIO}

Capítulo I - Do caminho percorrido à emergência inicial do tema .p.10

1. Introdução .p.10

2. O percurso até a pesquisa e o MSE p.13

3. Onde está o pai? A figura paterna e a matrifocalidade.........................................................p.18



5. Método, contornos e o caminho............................................................................................. 24

Capítulo II - As mulheres p.30

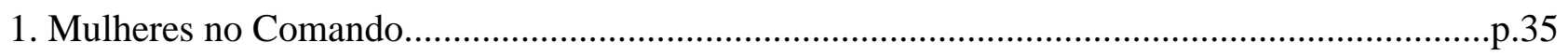

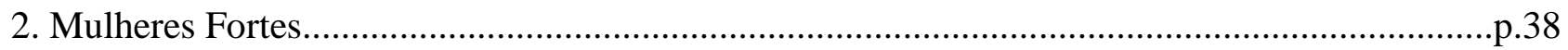

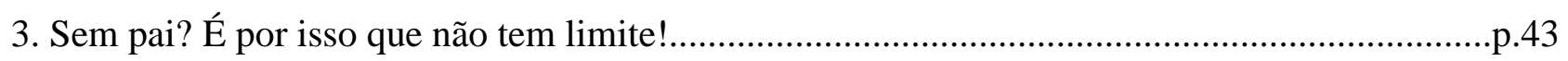

Capítulo III - O "homenzinho da casa" p. 47

1. Filho (homem) deslocando-se de lugar.................................................................................. 51

2. O trabalho e o posicionamento masculino.....................................................................................59



4. Trabalho, MSE e relação mãe-filho.......................................................................................p.69

Capítulo IV - Sinais da possível emancipação feminina e o lugar do homem.......................p.78

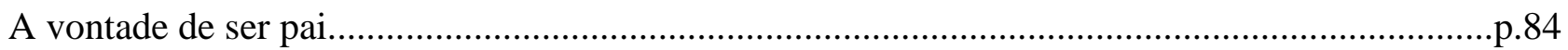


1. Lugares de homem e de mulher.....................................................................................p. 90

2. Cenas de outros grupos: O preço da "emancipação" ou do inchaço das tarefas femininas........p.97

Capítulo VI - Considerações. .p.103

Referências. .p.106

Anexo. ..p. 110 


\section{Capítulo I}

\section{Dos caminhos percorridos à emergência inicial do tema}

\section{Introdução}

\section{Setembro de 2012. Serviço de Medidas Socioeducativas em Meio Aberto de Campo Limpo, São Paulo-SP.}

Como técnico/psicólogo, era responsável por acompanhar e atender Lucas ${ }^{1}$, adolescente de 15 anos que cumpria medida socioeducativa.

Depois de alguns meses em atendimento, um interessante diálogo:

- E aí Lucas, tudo certo? Quando vou conhecer seu pai ${ }^{2}$ ?

- Agora tu é minha noiva pra querer conhecer meu pai (risos)?

- Não apareceu no grupo de família de novo. Tudo bem, mas você e sua mãe disseram que ele viria, aí eu fiquei esperando, e nada.

- É, ele é assim mesmo... Mas, minha mãe e minha irmã vieram?

- Assim como a mãe, irmã, madrasta e tia de todos os outros adolescentes. É impressionante como só vêm as mulheres. Trabalho aqui faz oito meses e conheço pouquíssimos pais, irmãos, padrastos, tios. Não consigo entender...

- Iiii, tá virando gay agora? Querendo ver só os homens. Você não disse que estudava morte, assassinato, essas coisas?

- É, por aí. As consequências do homicídio na família. Meu mestrado.

- Então?

- Então o que, Lucas?

- Isso que é coisa de homem. Tiro, morte...

- É? E o que que é coisa de mulher?

1 Todos os nomes são fictícios, a fim de preservar a identidade dos referidos. Em muitos casos que serão apresentados realizarei algumas modificações em dados que possam identificá-los, pelo mesmo motivo. Alguns primos podem ser tios, as primas, irmãs, uma manhã, noite. Evidente que tais alterações foram realizadas de modo a não prejudicar o conteúdo central do que será discutido.

2 Os diálogos, sejam em cenas ou nos casos, terão linguajem coloquial para nos aproximarmos de como realmente aconteceram. Com isso, nesses trechos, vícios de linguajem ou erros gramaticais serão, cientemente, descritos, respeitando a peculiaridade de cada encontro. 
- Ah, essas coisas de família, grupo de família, cuidar, vir aqui.

- Ah, então você não se preocupa com a sua família? E se sua mãe estiver doente, se alguém bater no seu irmão...

- Se alguém encostar um dedo no meu irmão, eu encho o cara de bala!

- Ah, porque dar tiro em quem mexeu com o irmão é coisa de homem?

- Isso! Claro!

- Humm... (risos).

- Tá rindo do quê?

- Nada, Lucas, é que eu achei que você tivesse me dito que se preocupar com a família fosse coisa de mulher.

Lucas foi um dos adolescentes com quem trabalhei que pouco tempo depois veio a falecer. Levou um tiro de um policial militar à paisana.

$\mathrm{Na}$ época, eu ainda trabalhava no Mestrado com o tema do impacto de mortes por homicídio na dinâmica familiar. Após a morte do jovem, fiz contato algumas vezes com a família, a fim de oferecer algum tipo de auxílio. Foram poucos e breves telefonemas com a mãe e a irmã mais velha. Um tempo depois, recebi a ligação do pai do Lucas. Ele me insultou e disse para não ligar mais, reviver o assunto o machucava demais. Assim fiz. Foi o primeiro, único e último contato que tive com o pai do jovem, após três meses de trabalho com o garoto.

Compreendi o quão delicado era aquele momento para a família. Depois de algumas semanas, pelas dificuldades no contato com essas famílias e a influência de outros elementos, como os lugares de homens e mulheres dentro do grupo familiar, que explicitarei mais a frente, a mudança que fiz do tema do presente trabalho mostrou-se pertinente e necessária.

As conversas que tive com Lucas, como no breve diálogo acima, sobre "coisa de mulher" e “coisa de homem", permaneceram vivas em mim por um bom tempo. Não era incomum tê-las com outros adolescentes e com seus parentes (às vezes o assunto vinha de forma direta, outras indireta). Impressionava-me como certas concepções de gênero afetavam substancialmente as relações familiares e grupais.

Ações classificadas como femininas, como comparecer às atividades do serviço, cuidar dos filhos, zelar pela casa, enquanto os homens eram aqueles da rua, que trabalham fora, se arriscam em tiroteios quando no tráfico, não comparecem em atividades relacionadas ao filho, pareciam estar impregnadas no imaginário do que seria ser "homem" e "mulher" para muitos deles. 
Essas concepções de masculino e feminino que habitavam o senso comum compartilhado, muito calcadas em um ideário tradicional de família fixado na heteronormatividade, na presença da família nuclear, impactavam fortemente o cotidiano das famílias, afetavam o comportamento dos adolescentes, influenciavam atitudes e ditavam as dinâmicas familiares.

O que me chamou também muito a atenção foi que na prática esses lugares de homens e mulheres dentro do grupo familiar mostravam-se um pouco diferentes do que era dito. Os filhos homens, em alguma medida, também ajudavam a criar os irmãos mais novos, as mulheres trabalhavam fora, os homens estavam muitas vezes desempregados, alguns ajudavam nos afazeres domésticos e existiam famílias homoafetivas ${ }^{3}$. Era curioso notar como discurso e prática destoavam e ao mesmo tempo conviviam.

No serviço de Medidas Socioeducativas em meio aberto (MSE), em particular, as características mais claramente constatadas nas famílias atendidas diziam respeito à grande presença das mulheres (em especial, as mães) em múltiplas atividades que englobavam o cotidiano dos filhos e da família - elas trabalhavam dentro e fora de casa, centralizavam as funções familiares, lidavam com os programas de transferência de renda e exerciam significativa influência nas atitudes de todos dentro do grupo familiar. Enquanto os homens...

A impressão que se tinha era de que se multiplicavam as atitudes das figuras femininas em relação aos adolescentes. Elas eram presentes, ativas e, na medida do possível, disponíveis a acumular mais funções. Já as figuras masculinas (em especial, a paterna), pareciam estar debaixo de uma grande nuvem. Existiam poucas informações concretas, contatos, quase não se falava e parecia haver pouco investimento familiar neles.

Quem eles eram? Onde estavam? Qual, afinal, o lugar deles nessas famílias?

Essas perguntas introduziram-me na temática do presente trabalho. Baseado em minha experiência com aqueles com que tive contato no serviço, ou seja, em sua maioria mulheres e os jovens - busquei averiguar a produção de sentidos sobre lugar dos homens nessas famílias.

3 Tive pouco contato com famílias homoafetivas (apesar de não ser difícil encontrá-las). No entanto, não discutirei aqui esses casos por ter pouco material para discorrer sobre elas de maneira apropriada. 


\section{O percurso até a pesquisa e o MSE}

A trajetória desta pesquisa, desde o início até seu tema definitivo, sofreu grandes modificações devido às vicissitudes encontradas no campo trabalhado. O título anterior era: Família e violência urbana: o impacto de mortes por homicídio na dinâmica familiar. Ele surgiu da minha participação em reuniões e seminários do Projeto de produção e disseminação de trabalhos referentes às tecnologias de intervenção psicossocial no campo da juventude, da sexualidade e da violência, do qual participaram grupos de professores, estudantes e técnicos de diversas unidades da Universidade de São Paulo, com financiamento da Fundação Ford.

Concomitante a essas atividades, realizei minha iniciação científica sob a orientação da Profa. Belinda Mandelbaum, entre o segundo semestre de 2010 e o primeiro de 2011, que teve como objetivo analisar e compreender a forma e o contexto de como a violência urbana atingiu algumas famílias da periferia de São Paulo. O trabalho teve origem no desdobramento das pesquisas: "O impacto das mortes por homicídio e AIDS na saúde e nos direitos das crianças e jovens na cidade de São Paulo" e "Estigma e Discriminação Relacionados ao HIV/AIDS: Impactos da Epidemia em Crianças e Jovens na Cidade de São Paulo", em que foram entrevistados, entre 2006 e 2007, crianças e jovens cujos pais morreram por AIDS ou homicídio (a faixa etária era de zero a 24 anos; das crianças até 15 anos, foram entrevistados os cuidadores; de 15 a 24 anos, os próprios jovens). Foi utilizado um longo questionário aberto e, para a finalidade de nossa pesquisa, escolhemos analisar as respostas emitidas por jovens (15 a 24 anos) e cuidadores das crianças para uma das perguntas realizadas: Você lembra alguma situação em que sentiu a sua própria segurança ou a segurança do(a) criança/adolescente ameaçada por violência? Descreva. Dentre os resultados, verificamos como a violência apresenta-se cotidianamente nessas famílias, de maneira gratuita, difusa, em que o medo é constante, seja de traficantes ou seja de policiais que frequentemente abusam da autoridade. Foi possível entrever também, nas respostas, a tentativa de elaboração do trauma da perda de um pai ou mãe, e vimos ainda como se torna difícil o processo de luto devido, principalmente, à constante convivência com a violência, o sentimento de impunidade e o jogo de retaliações ocasionado pela estigmatização da família que sofre a perda.

Algumas indagações surgiram daí, pedindo aprofundamento: como a morte por violência urbana ressoa no ambiente familiar? Como a família se reorganiza e se reestrutura levando em consideração as fantasias e os processos de luto envolvidos na elaboração dessas cenas de violência? Deste trabalho, caminhamos para o projeto de Mestrado, que tinha como objetivo 
analisar os diferentes impactos de mortes por homicídios em dinâmicas familiares, utilizando as ferramentas da Psicanálise da Família (Mandelbaum, 2010; Berenstein, 1988; Eiguer, 1985). Seria investigada a maneira como a família se defronta e lida com a perda por homicídio em situações de violência urbana e como a atuação do psicoterapeuta de família poderia contribuir para a elaboração, pelo grupo familiar, dessa experiência. Para tal empreendimento seriam realizados atendimentos, a partir de uma compreensão psicanalítica, com famílias que perderam algum dos seus por morte violenta.

Paralelamente aos estudos da literatura sobre família e violência, eu trabalhava como técnico no MSE, na região de Campo Limpo, zona sul de São Paulo. Esse serviço, que é referenciado ao Centro de Referência Especializado da Assistência Social - CREAS, destina-se a jovens de 12 a 18 anos incompletos que estão em situação de conflito com a lei. Antes exercido pela Fundação CASA, o MSE, há sete anos, baseado no ECA (Estatuto da Criança e do Adolescente) e no SINASE (Sistema Nacional de Atendimento Socioeducativo), se descentralizou e realiza suas atividades utilizando convênios com ONGs e entidades sociais para que nesses espaços os adolescentes possam cumprir as medidas de Prestação de Serviço à Comunidade e/ou Liberdade Assistida. Na primeira medida, a de prestação de serviços à comunidade, o adolescente deve realizar tarefas gratuitas de interesse geral, que não comprometam sua integridade e levem em consideração suas aptidões. Na segunda, a de liberdade assistida, o jovem é acompanhado, auxiliado e orientado pelo técnico responsável durante o período de medida determinado, passando por atendimentos individuais e familiares, além de intervenções conjuntas (técnico, adolescente e família) em relação à escola, cursos profissionalizantes e providências quanto à documentação básica (RG, CPF, Certidão de Nascimento, Título de Eleitor). Em todo o percurso é informado ao Poder Judiciário por meio de relatórios ou presencialmente o processo de cumprimento da medida (SINASE, 2012).

O trabalho do técnico, dessa forma, não visa uma psicoterapia, mas é interdisciplinar e abrange o grande entorno do adolescente, sendo responsável não somente pelos atendimentos individuais semanais, mas também em auxiliar o adolescente naquilo que concerne seu ambiente social, familiar e sua situação judicial.

Apresentarei um exemplo hipotético para fornecer uma melhor visão do trabalho por mim exercido no MSE e evidenciar o frequente contato que tínhamos com os equipamentos institucionais.

O MSE possui abrangência distrital e cada um deles possui sua própria composição, dependendo, dentre outros fatores, da demanda que há no local. O serviço de Campo Limpo tem em sua composição 12 profissionais: oito técnicos - profissionais com formação em Psicologia, 
Assistência Social ou Pedagogia, que são responsáveis por acompanhar os adolescentes; dois administrativos; uma pessoa para os serviços gerais, responsável pela limpeza e a cozinha, e um gerente, que coordena todo o serviço.

Quando um adolescente residente no distrito comete uma infração e é designado o cumprimento de medida em meio aberto, ele, acompanhado de um familiar com mais de 18 anos, deve se encaminhar ao serviço. O primeiro contato, chamado "Acolhida", é um atendimento realizado por dois técnicos, que ficam responsáveis por apresentar a instituição a ambos (o jovem e o familiar) e por esclarecer possíveis dúvidas sobre como será a medida socioeducativa, depois que se realiza o Plano Individual de Atendimento (PIA). Este é baseado em um questionário que coleta informações gerais sobre o adolescente e sua família, com a finalidade de estabelecer inicialmente um plano de atendimento específico ao jovem.

Após esse primeiro contato, os técnicos relatam o encontro para todo o grupo do MSE (técnicos, gerente e o administrativo), em uma reunião semanal em que se discute qual técnico será mais adequado para acompanhar o caso. Supondo então que Pedro cumprirá a medida de Prestação de Serviço à Comunidade durante três meses/três horas: serão realizados os primeiros atendimentos semanais de uma hora para conhecê-lo, estabelecer possíveis vínculos e trabalhar questões pertinentes, tais como, aspectos pedagógicos, dificuldades de acesso às instituições de saúde, questões de relacionamento familiar, entre outras. Será analisado junto ao garoto, baseado em suas aptidões e características, qual o local mais adequado para a realização da medida socioeducativa. Supondo que seja escolhido o trabalho com crianças em uma CEI (Centro de Educação Infantil), estabelece-se contato com a instituição e programam-se atividades que sejam condizentes com Pedro. Ele desempenhará a função designada por três horas, uma vez por semana, durante três meses.

Concomitante a isto, verifica-se a situação escolar, se ele está estudando, em que série parou, e contata-se, se for o caso, uma nova instituição escolar para matrícula. Se houver dificuldade de aprendizado, pode-se recorrer ao EJA (Educação para Jovens e Adultos) ou ao MOVA (Movimento de Alfabetização para jovens e adultos). Propõem-se cursos profissionalizantes em SESCs (Serviço Social do Comércio) e atividades culturais em CEUs (Centro Educacional Unificado) ou em ONGs. Na realização da visita familiar, é discutido o acesso que a família tem a escolas, hospitais, centros de lazer e cultura, programas de transferência de renda como o Bolsa Família e o Renda Cidadã.

Uma vez por mês são organizados grupos de discussão com as famílias em conjunto, nos quais temas pertinentes ao cotidiano, que usualmente surgem durante os atendimentos ou em conversas informais com os integrantes do grupo familiar - como a redução da maioridade penal, a 
violência doméstica e a policial - são abordados.

Por ser uma região com altos índices de criminalidade e violência, tive contato com alguns jovens que tiveram em seu histórico familiar recente casos de mortes por homicídio. Pretendíamos realizar a pesquisa com esses meninos. No entanto, o que pude notar foi uma enorme dificuldade de que essas famílias se disponibilizassem a comparecer à instituição para o início de uma entrevista. Os movimentos de evitação/recusa eram vários: umas diziam que simplesmente não queriam; outras que gostariam, mas, depois de agendados os atendimentos, faltavam constantemente; e outras, após o primeiro contato telefônico, não mais respondiam.

Aos poucos fui me embrenhando, me deixando envolver pelo trabalho com os adolescentes e deixei de lado esse tema por conta das particularidades e vicissitudes do campo que foram me afetando.

O MSE realiza seus serviços em uma casa bem grande, antiga, na rua conhecida pela comunidade por ter a tradicional feira do bairro. Certo dia, no período da manhã, eu havia realizado uma visita institucional à escolar para requerer matrícula a um dos jovens por mim atendido. Deparei-me com muitas mães conversando com os professores a respeito de seus filhos, desde trâmites burocráticos até notas baixas - eu era o único homem a acompanhar um garoto. Voltando para o serviço, passo pela feira e vejo, na grande maioria, mulheres a comprar. Chego para a reunião que decidirá o tema a ser trabalhado no grupo de família, e decidimos sobre "violência doméstica", visto termos muitas mulheres no grupo. Fim da reunião, hora do almoço, todos em volta da mesa, técnicos e gerente. Enquanto como, espero um pai com quem falei ao telefone sobre a importância de sua presença no atendimento familiar, e ele disse que viria. Avisam-me que a família do adolescente havia chegado, estava na porta do serviço me esperando. Dou uma olhada. Estavam a tia, a mãe e a namorada do jovem. Perplexo, comento à mesa:

"Só existem mulheres na vida desses meninos?"

Todos se entreolham por um segundo e dão longas risadas. Em seguida, uma das técnicas me responde:

"Por quê, João? Quem você estava esperando?" 
Essa não foi uma cena do início do meu trabalho, eu já estava me acostumando a atender somente mães, avós, vizinhas, e a lidar somente com mulheres nas instituições com as quais tinha contato. Quase naturalizando a ausência masculina. Mas ao experimentar esse contexto social e me aproximar do cotidiano das instituições e das famílias desses jovens, fui pego por essa constatação. Em todas as atividades realizadas pelo serviço, para as quais as famílias dos adolescentes eram convocadas, a imensa maioria dos que compareciam eram mulheres - mães, madrastas, avós, tias e irmãs mais velhas.

Atestava-se esse fato já de início, quando o jovem e o familiar compareciam pela primeira vez ao MSE e respondiam ao PIA. Dentre as questões, pergunta-se sobre o pai, como ele se chama, o que faz, quanto ganha ${ }^{4}$. Nesse momento, normalmente com a mãe ao lado, era comum perceber em ambos certa hesitação em responder. "É...”, “Bom...”, “Depende...”. Via-se que esse mal estar não era referente somente ao impacto de perguntas invasivas e muitas vezes desnecessárias, pois quando eram referidas a outros membros da família como tios, avós, irmãos (sempre por parte de mãe), as respostas eram mais diretas. Havia aparentemente pouco conhecimento a respeito da trajetória e do histórico que a figura parental (pai/padrasto) tinha na família. É claro que muitas dessas questões tocam em sigilos familiares difíceis de lidar, causando constrangimento; e que se o pai estivesse presente, muitas dessas informações talvez pudessem ser esclarecidas. O fato, entretanto, era que ele não estava e recorrentemente havia confusões a seu respeito.

Dentro do MSE havia muitas atividades envolvendo familiares. No entanto, aquelas que os pais/padrastos menos (ou nunca) compareciam eram os atendimentos de família. Nesses, as questões recorrentes envolviam a escola, o trabalho, o tráfico de drogas, o relacionamento com os irmãos e a mãe. A figura paterna aparecia aí como marginal, por vezes com pouca ou nenhuma importância aparente.

"Ele não vem hoje, mas vamos começar logo, temos muito que falar...", "Meu filho nunca precisou de pai não, criei e dou conta de criá-lo sozinha”, "Ah, se pelo menos o padrasto se interessasse em levá-lo mais pra jogar bola, ficasse mais próximo, ajudaria, mas também, não é filho dele...", "Vem cá, porque você pergunta tanto de pai, padrasto, essas coisas... você tem algum problema com isso?".

Devido às excelentes colocações e indagações endereçadas a mim, como esta última feita por um curioso adolescente, fui me questionando se havia algum problema de a figura paterna não

4 Infelizmente não é o momento neste trabalho para problematizar o porquê e a quê serve um questionário destes. 
estar presente em algo tão importante para o jovem quanto o processo de medida socioeducativa.

As visitas domiciliares sem dúvida foram as que mais me impactaram. Ao adentrar as casas, além de testemunhar a grande precariedade em que viviam as famílias desses jovens, pude de novo notar o quanto elas eram hegemonicamente "femininas", no sentido de que eram as mães, avós, tias que nos recebiam, conversavam e nos apresentavam a casa e a todos, inclusive maridos, namorados, filhos e irmãos, quando estes estavam presentes. Eram elas que comandavam todo o processo. Importante pontuar que, diferente do que se possa pensar, as mulheres estavam em casa não porque não trabalhavam, enquanto os homens estavam ausentes por estarem em seus empregos. As mulheres também trabalhavam fora e havia constantemente grande dificuldade de se agendar uma visita, pois durante a semana no horário comercial elas não poderiam nos receber, por estarem em seus serviços.

Como, então, essas mulheres se organizam para criar seus filhos, já que possuem uma jornada tripla - dentro de casa, com trabalhos domésticos e atribuições afetivas, simbólicas, formativas em relação aos filhos e familiares, e o trabalho convencional para o sustento econômico? Usualmente recorrem a parentes que moram próximos, instituições, vizinhos e amigos com quem deixam as crianças quando vão para o emprego, voltando para casa à noite, quando retornam aos cuidados dos filhos.

\section{Onde está o pai? A figura paterna e a matrifocalidade}

Após essa breve descrição do trabalho realizado com a comunidade e famílias desses adolescentes, a pergunta que emerge é: onde está o pai?

Se procurarmos caso a caso, teremos respostas. "O pai dele sumiu no mundo, ninguém sabe onde está". "Ele mora no quarteirão de baixo, aparece aqui quando está bêbado". "Ele é gente boa”. "Meu filho não tem pai, pode colocar aí: SEM PAI”. "Ele morreu”. "Ele mora com a gente, não vem aqui porque trabalha demais". "Foi assassinado". "Não sei quem é".

Evidente que há pais participantes da vida do filho, que se comprometem com a família e que, mesmo às vezes não comparecendo à medida socioeducativa, se preocupam, telefonam. Outros estão distantes, morando em outras cidades e estados, mas exprimem o desejo de estarem próximos; há configurações em que o pai é figura de referência e a mãe é ausente. Esses casos, contudo, fazem 
parte de uma minoria das famílias com que tive contato.

Analisando atentamente então, podemos depreender a partir dessas experiências que, com certa frequência, a figura paterna é aparentemente pouco conhecida (seja em seu histórico de vida ou em características pessoais), enfraquecida (possui pouca influência familiar) e, muitas vezes, ausente (fisicamente).

As configurações familiares mostraram-se diversas, predominantemente não nucleares, variando entre famílias extensas com avós, tios, primos, filhos - sendo estes últimos em grande parte fruto de diferentes relacionamentos - e famílias monoparentais compostas apenas de mãe e filho. Essas famílias têm a mulher, normalmente a mãe, como centro das relações e organizações familiares, detentora das tomadas de decisão, ocupando de forma significativa o cotidiano dos adolescentes, sendo frequentemente referida nos atendimentos. São as mulheres, portanto, participativas nas atividades relacionadas aos filhos (seja dentro ou fora de casa), líderes familiares e grandes responsáveis pelo sustento econômico.

Vale lembrar, mais uma vez, que todo meu contato com esses núcleos familiares, devido às características do trabalho, não se restringiram ao ambiente interno do MSE, sendo este apenas parte de minha função. Trabalhávamos com todo o equipamento institucional distrital (governamental, privado ou em sistema de convênio), realizando interações com a rede conforme o necessário. Verificando o entorno pude perceber que essas características familiares das quais estamos tratando estavam presentes não somente nas famílias envolvidas com o serviço, mas em toda a comunidade.

A nossa intenção não será a de procurar a conjuntura de motivos que levaram esses jovens a infracionarem. O fato de estarem no MSE será uma informação que comporá outras a respeito dele que, por sua vez, está inserido em uma formação maior, que é a sua família. Dessa forma, nos voltaremos para a complexidade familiar e tentaremos compreender melhor algo de sua dinâmica.

Que universo familiar era esse no qual eu estava adentrando? Se as mulheres estão por toda parte, onde estariam os homens nessas (dessas) famílias?

O modelo de família que habita boa parte do imaginário social comum - pai, mãe e filhos não condiz com a realidade brasileira. Segundo o IBGE (2009), 50,1\% das famílias não são constituídas de casais com filhos. As famílias a que nos referimos aqui se apresentam de maneira 
mais complexa, rica, com vários atores participando, sendo eles parentes ou não, com múltiplas funções e diversas formas de se relacionar que não lembram em nada o modelo de família nuclear com padrões de comportamento pré-estabelecidos.

A grande importância que tem a mulher nas famílias em detrimento do homem é uma das características que se mostraram relevantes também na pesquisa demográfica. A chefia feminina no Brasil cresceu muito nos últimos anos. O conceito de "chefia" utilizado pelo IBGE é dado a partir da pessoa de referência da casa, ou seja, é a pessoa responsável pela unidade domiciliar ou que é assim considerada pelos demais membros. De acordo com os dados do IBGE (2009), a chefia feminina no Brasil cresceu 35\% entre os anos de 1995 e 2005, passando de 22,9\% para 30,6\% das famílias; em 2009, chegou a 35,2\%. As idosas são as que têm maior expressividade, chegando a $41 \%$ das famílias que são chefiadas por mulheres, em 2009. A porcentagem de mulheres sem o cônjuge com filhos chega a 17,3\% das famílias, enquanto a monoparentalidade masculina é de $2 \%$.

O termo "chefia feminina" não possui a complexidade necessária para abarcar toda a gama de relações internas familiares a qual queremos nos referir. O sociólogo Raymond Thomas Smith em meados do século XX estudou famílias na Guiana Inglesa que apresentavam uma rede de relações parentais em que a parte feminina é mais favorecida do que a masculina (Smith, 1956). Dentre as características encontradas nesses grupos, destaca-se o fato de que a relação mãe e filhos é mais solidária do que a de pai e filhos, a proximidade do núcleo familiar com a matrilinearidade ${ }^{5}$ é dominante, as decisões relativas à casa ficam a cargo delas e outras relações como trocas de favores e bens são realizados pelo lado feminino; a essas famílias foi dado o nome de matrifocais (Smith, 1973; Scott, 1990).

A matrifocalidade independe de classes sociais (apesar da maioria dos estudos ser realizada com populações de baixa renda) e é caracterizada por formas de relação não somente intrafamiliares, mas também com vizinhos, amigos e parentes fora de casa (Scott, 1990). Smith (1973) descreve como o papel das mulheres se modifica dentro do desenvolvimento familiar ${ }^{6}$, principalmente nas suas relações com os filhos. Primeiramente, sua principal função quando está com o companheiro dentro de casa (sendo marido ou não) é cuidar dos filhos, e dessa forma ela é totalmente dependente financeiramente do companheiro; o homem, por sua vez, não participa da criação dos filhos, bem como das atividades domésticas. Em um segundo momento as crianças, tendo certa idade, passam a ajudar nas tarefas de casa, oferecendo à mãe maiores condições para trabalhar fora. Com isso, a mulher passa a contribuir financeiramente, obtendo papel central na

5 Matrilinearidade refere-se à linhagem de parentes pertencentes à família materna.

6 O autor utiliza o conceito de ciclos familiares (Fortes, 1958) para explicar o desenvolvimento familiar. 
tomada de decisões junto aos filhos, já que além de ser detentora da coalizão afetiva familiar, tornase também partícipe da coalizão econômica (Smith, 1973 apud Scott, 1990).

O sistema matrifocal, tal como descrito por Smith (1973), em alguns aspectos assemelha-se com o que vimos, já que leva em consideração toda a multiplicidade de fatores, inclusive os econômicos, que influenciam as dinâmicas dessas relações familiares. No entanto, denominar como matrifocais as famílias estudadas em Campo Limpo seria um erro, pois traríamos para elas toda uma bagagem de aspectos próprios da população estudada pelo autor que não necessariamente condizem com a nossa; muitas características mostram-se distintas.

Smith trabalha com o conceito de ciclos familiares, conceito que não utilizaremos, pois entendemos que tal perspectiva pode encobrir e aplainar determinadas características que se fazem importantes, ao setorizar períodos de vivência. No sistema matrifocal proposto pelo autor, os filhos e filhas, ao ganharem idade, formam com a mãe "blocos políticos" que servem de relação de alteridade ao pai. Tal fato não foi verificado nos grupos familiares de Campo Limpo, tampouco os fortes laços afetivos entre as mulheres da casa, formados pelas atividades maternas em comum ${ }^{7}$ (Smith, 1973 apud Fonseca, 2004).

Se são diferentes, por que trazer esse conceito? Há algumas características do sistema matrifocal que podem nos ajudar a pensar a dinâmica das famílias atendidas, dentro do contexto em que vivem. Portanto, não falaremos da matrifocalidade da Guiana Inglesa do século passado, mas sim de matrifocalidades, presentes em um bairro periférico de São Paulo entre 2012 e 2013, utilizando o termo na ausência de outro melhor para referenciar essa configuração familiar. Por isso as aspas no título do trabalho.

Para explicitar, então, quais são essas características, definirei, inicialmente, o que chamarei de família matrifocal. É aquela em que a mãe é figura principal do grupo doméstico, exercendo grande influência sobre os outros integrantes; além dela, são as outras mulheres da família que têm o poder de decidir sobre os assuntos relacionados às crianças e o funcionamento da casa; e a maioria dos contatos dos membros são matrilineares.

Antes de continuar, devemos apresentar dois pontos essenciais que atravessarão todo o trabalho. O primeiro deles diz respeito à necessidade de apesar de reconhecer a presença desses aspectos nas famílias do bairro de Campo Limpo em geral, devemos ter a ciência de que as questões que me mobilizaram emergiram no trabalho com famílias que frequentaram o MSE. Colocaremos esse grupo como protagonista da pesquisa. Problematizaremos, portanto, fatores que os envolvem e

7 Em muitos casos há uniões entre as mulheres das famílias que atendi. No entanto, essas não eram necessariamente formadas devido à atividades maternas em comum 
evidenciaremos questões que surgiram a partir da sua especificidade.

O segundo fala da necessidade de lembrar que estamos falando de uma população de baixa renda. Trabalharemos com a realidade da periferia de São Paulo, já que foi ela que nos inspirou este estudo. Campo Limpo encontra-se entre os distritos mais pobres da cidade, possuindo índice de vulnerabilidade social considerada "alta", segundo a Fundação Sistema Estadual de Análise de Dados - SEADE. O bairro lidera as estatísticas das regiões mais violentas da cidade. Segundo a Secretaria de Segurança Pública do Estado (SSP), foram registrados na região 3.665 casos de crimes violentos entre janeiro e setembro de 2011, dentre eles homicídios, tentativas de homicídios, latrocínios e assaltos em geral.

Segundo alguns estudos (Woortman, 1987; Neves 1985; Scott, 1990; Quintas, 1986; Sarti, 2007 [1996]), grosso modo, nessas condições de pobreza, os homens não conseguem prover financeiramente os gastos familiares, o que abre caminho para as mulheres saírem de casa, em direção ao trabalho remunerado fora. Essa situação tensiona a relação conjugal, pois o homem desloca-se de sua posição de provedor, enquanto a mulher, além de ocupar esse papel, mantém o de "cuidadora" na criação dos filhos e o de chefia nos afazeres domésticos. Com toda uma centralidade na figura feminina, o homem perde espaço fora de casa e se ausenta de dentro (ou é colocado para fora), o que impacta toda dinâmica interna do grupo.

Apresentei, de forma geral, o conceito de matrifocalidade cunhado por Smith (1973), por verificar nele semelhanças com a constituição familiar de grande parte da população com que tive contato nos 12 meses de trabalho na região de Campo Limpo, e o utilizarei como ferramenta para refletirmos sobre essas famílias. Trata-se inicialmente, portanto, do resultado de minha experiência com as famílias do local.

O que está em números e corrobora com o verificado na prática, são as estatísticas que evidenciam a crescente emancipação da mulher na sociedade brasileira. Além do aumento da chefia feminina nas unidades domésticas, o número de mulheres atingindo o mercado de trabalho formal, segundo dados do IBGE em 2010, nunca foi tão alto, chegando a 43,9\%. A taxa de fecundidade é a mais baixa já registrada no país, chegando a 1,9 filhos por mulher (IBGE, 2010). Todos esses indicadores apontam uma maior liberdade de trânsito da mulher tanto na esfera da rua, como na casa. Este estudo, dessa forma, estará imerso não apenas em experiências práticas de um local, mas remete a uma importante mudança que vem ocorrendo nas constituições familiares contemporâneas 
brasileiras, que, nos casos analisados, evidenciou-se pelos resultados de uma possível emancipação feminina e/ou fruto de contingências ligadas à pobreza.

E o homem nessa história? Dentro desse cenário, levando em conta o contexto socioeconômico exposto, o questionamento que naturalmente se reedita é: qual a situação da figura masculina nessas famílias? Russel Parry Scott (1990), no artigo O homem na matrifocalidade: gênero, percepção e experiências no domínio doméstico, aborda, do ponto de vista sócio antropológico, a situação do homem em famílias matrifocais no bairro dos Coelhos, região pobre de Recife-PE. Ao detectar aspectos relevantes ligados à mulher e à matrifocalidade, tendo como ponto de partida a "casa", o autor discute questões como o afastamento do homem do domínio doméstico, a entrada da mulher no mercado de trabalho e a divisão de gênero, tendo o homem como o "provedor" e a mulher a "cuidadora". Em determinado momento aponta:

O outro lado da equação (de como o homem lida com a esfera da casa) tem suscitado muito menos investigação e pouca articulação entre os autores que abordam a questão de enfoques diferentes. (...)

Continua a existir uma lacuna em nossa compreensão de como aquele homem, que é patriarca potencial, sendo intermediário entre o mundo da rua e da casa, e que vive na favela, enfrenta a própria incapacidade de controlar a rua, o que lhe impede de trazer subsídios para exercer o poder em casa. Como é que pode transportar sua experiência de "dominado" (no mundo legal e jurídico da rua) numa experiência de "dominador" efetivo em casa? (Scott, 1990, p. 40).

\section{Objetivo}

Seguindo o caminho traçado por Scott (1990), o objetivo deste trabalho, portanto, será o de investigar algumas produções de sentidos sobre o lugar do homem na dinâmica familiar, segundo os integrantes dessa configuração que chamei de matrifocal, dentro do contexto apresentado.

Para isso utilizarei os atendimentos e vivências que tive com as famílias como 
técnico/psicólogo no MSE. Como no meio no qual eu estava inserido a maioria da população atendida era de mulheres e adolescentes, o resultado da pesquisa estará atravessado por esse viés.

O tema proposto não foi previamente escolhido, tendo emergido ao se apresentar no cotidiano do trabalho, que englobou diversas facetas de práticas institucionais e atendimentos individuais e de grupo. Apesar dos atendimentos frequentemente possuírem caráter clínico, não se trata de uma psicoterapia tradicional, pois as relações com os adolescentes e famílias estavam atravessadas pelo contexto e posição nos quais eu estava inserido: funcionário da instituição MSE Campo Limpo, exercendo a função de técnico. A relação, portanto, era construída dentro e fora da sala de atendimento, com intervenções que abarcavam também o âmbito social (verificar e acionar, por exemplo, programas da assistência social pertinentes a cada família) e o pedagógico (realização de leituras com o adolescente, caso fosse uma demanda importante).

\section{Método, contornos e o caminho}

O material a ser utilizado tem origem na complexidade de minha experiência no MSE, envolvendo desde conversas informais no café da manhã até longos atendimentos individuais. Separarei as cenas, casos e atendimentos que contribuirão para uma melhor análise do tema proposto.

O método que entendemos ser o mais adequado para o desenvolvimento da pesquisa seria aquele que nos deixasse livre o suficiente para captar e utilizar essas experiências em sua multiplicidade. Peter Kevin Spink (2003), em seu texto Pesquisa de campo em Psicologia Social: uma perspectiva pós construcionista, discute a noção de pesquisa de campo em psicologia social, apresentando as dificuldades de realizar estudos em um campo fisicamente determinado e limitado. Com isso, propõe a noção de "campo-tema", em que a pesquisa tradicional segundo a qual o pesquisador vai até o campo, coleta dados e os analisa segundo diversos métodos é deixada de lado em favor de um estudo onde o campo não se limita ao âmbito espacial, mas a toda processualidade de temas que a ele está referido.

Campo, entendido como campo-tema, não é um universo "distante", "separado", "não relacionado", "um universo empírico" ou um "lugar para fazer observações”. Todas estas 
expressões não somente naturalizam, mas também escondem o campo, distanciando os pesquisadores das questões do dia-a-dia. Podemos, sim, negociar acesso às partes mais densas do campo e em consequência ter um senso de estar mais presente na sua processualidade. Mas isso não quer dizer que não estamos no campo em outros momentos; uma posição periférica pode ser periférica, mas continua sendo uma posição... Campo, portanto, é o argumento no qual estamos inseridos; argumento este que tem múltiplas faces e materialidades, que acontecem em muitos lugares diferentes (Spink, 2003, p. 28).

O primeiro contato com o campo, conforme explica o autor, se dá no momento em que o tema vincula-se ao pesquisador e, posteriormente, pelo contato com o cotidiano, atendo-se aos lugares e às micro relações ali existentes. $\mathrm{O}$ campo surge para mim, dessa forma, no trabalho no MSE. Analisarei, assim, a minha experiência não me detendo a fatores que tangem somente o serviço, mas ao todo vivido com as famílias.

A empreitada na qual estamos enveredando, portanto, será a de utilizar esse método para investigar a produção de sentidos em algo extremamente amplo tal como "o lugar do homem na família". Trata-se de um campo multifacetado, passível de inúmeros enfoques, embasamentos teóricos, recortes e vertentes que se interpenetram: sexo e gênero, feminilidades e masculinidades, sistema e estrutura familiar, a questão geracional, influências sócio históricas, lugares parentais (ser pai, marido ou filho, ou às vezes todos juntos), entre outros.

Como, então, analisar as experiências?

O tema é interdisciplinar e dentro de cada faceta há distintas possibilidades de desenvolvimento. Escolher somente uma faceta e desenvolvê-la, relacionando-a com as dinâmicas familiares, seria interessante. No entanto, não atingiríamos satisfatoriamente o objetivo proposto e sua complexidade temática. Por outro lado, abarcar muitos recortes em cada experiência nos levaria a análises superficiais.

O caminho encontrado foi realizar estudos de casos e descrever cenas para as quais abordarei temas pertinentes, estabelecendo possíveis ligações teóricas que me ajudam a compreender um pouco melhor o sentido produzido pelos familiares sobre o lugar dos homens. Não serão, assim, descritos muitos dos atendimentos e características dos acompanhamentos realizados, que também foram relevantes. Trazê-los o mais próximo de sua totalidade, inviabilizaria a análise 
que propomos, perdendo um foco que nos ajude a pensar a situação dos homens nessas famílias.

Serão trazidas também cenas de um Grupo de Família realizado a partir da temática desta pesquisa. Essa foi uma estratégia que visou trazer mais elementos para compreender o lugar dos homens nessas famílias.

O Grupo de Família, além de informar sobre assuntos pertinentes ao cotidiano das famílias, tem a função de aproximar o técnico de medida socioeducativa dos familiares do adolescente. O ambiente que é criado nessa atividade em específico é diferente do que é estabelecido nas outras atividades que ocorrem ao longo da semana. Toma-se café da manhã junto aos pais e é realizada uma dinâmica de grupo para descontrair - dinâmica em que os técnicos também participam. Criase, assim, uma situação em que as possíveis formalidades institucionais são deixadas de lado em detrimento de um momento não destinado às questões diretamente ligadas ao adolescente ou ao processo de medida socioeducativa que envolvem as mães, mas a questões especificamente delas.

Nesse cenário, torna-se propício o surgimento de muitos assuntos que usualmente não aconteceria dentro de um contexto institucional padrão. Um momento bastante interessante acontecia ao final do grupo, quando acabavam todas as etapas da atividade e era a hora de ir embora. No caminho para a porta de saída passava-se novamente pela sala onde era servido o café da manhã, a mesa continuava posta, ainda com bolos, frutas, café e sucos. Muitas mães paravam para comer mais um pouco e conversar pela última vez com o técnico do filho antes de sair. Ali ocorriam diálogos muito interessantes.

Discorremos, assim, sobre o lugar da figura feminina, bem como práticas e mudanças sociais que interferem nas concepções de mulher e homem dentro da família pobre brasileira. Será relacionada a matrifocalidade e o fenômeno da emancipação feminina com o deslocamento concomitante do lugar do homem na dinâmica familiar. Desenvolveremos também, como as três características da figura paterna/pai que verificamos nas famílias estudadas: aparentemente pouco conhecida (histórico de vida ou características pessoais), enfraquecida (pouca influência familiar) $e$ ausente (fisicamente) aparecem nos grupos familiares.

Poderemos notar não ser raro que determinadas características e questões emergem em mais de um caso. Diversos assuntos se entrecruzarão, o que pode sinalizar uma condição não apenas pontual.

Para o curso deste trabalho revisito escritos significativos que versam sobre matrifocalidade no Brasil, o que nos leva a textos da Antropologia, Sociologia e História, visto que na área da Psicologia não foram encontrados trabalhos relevantes sobre o tema. 
Considerando que a discussão se fará a partir das análises das dinâmicas familiares observadas durante o período em que estive no serviço socioeducativo. O lugar do filho, dessa forma, ganhará grande destaque não somente pela proximidade que tive com os adolescentes, mas em especial por dois fatores. Em primeiro lugar, a dinâmica apresentada na qual a figura paterna encontra-se "deslocada" emergiu em um posicionamento no qual a figura do filho ganhou evidência e importância em diversas ações e situações no interior da família. O outro fator é a marca social que o jovem recebe quando está inserido no MSE, ou seja, quando faz parte de seu reconhecimento social ter cometido infrações.

No capítulo II, As mulheres, serão trabalhados aspectos da matrifocalidade, do "enfraquecimento" do lugar do homem na dinâmica familiar, bem como sua desresponsabilização em aspectos familiares, além do sentimento de vergonha. Discorrerei sobre as mulheres fortes que centralizam as decisões, se responsabilizam pela família e que, ao desempenhar múltiplas funções familiares, se encontram constantemente muito cansadas e desgastadas física e emocionalmente.

No capítulo III, $O$ "homenzinho da casa", discutirei a partir de um caso esta característica que é bem comum nas famílias não apenas do serviço: relacionamentos entre mãe e filho principalmente em famílias monoparentais de chefia feminina em que ele se torna o "homenzinho da casa".

O filho ocupa um espaço que não é meramente o de um filho que ajuda nas despesas de casa e tem um relacionamento próximo com a mãe. Olhando mais de perto, há características que não condizem com um modelo "tradicional” de família que ambos ocupariam.

Ao ajudar nas despesas domésticas, o filho pode ocupar o lugar de provedor. Assim, refletirei sobre a reatualização de uma dinâmica de "família nuclear", agora com o filho realocado no lugar do pai. Nessa situação o adolescente pode até ocupar o lugar de provimento, mas a autoridade familiar que seria condizente com essa posição não lhe é delegada.

Analisarei também algumas cenas que estão relacionas com a especificidade do jovem em conflito com a lei e seu relacionamento com a figura materna.

No capítulo IV, Sinais da possível emancipação feminina e o lugar do homem, discutirei, no caso apresentado, como a paternidade atribuiu determinados sentidos para ações do jovem, principalmente relacionadas ao trabalho - evidenciando como um modelo "tradicional" de família, do homem provedor e a mulher cuidadora, ainda está presente no imaginário desse adolescente e 
contribui para moldar comportamentos. E depois, como a ex-namorada e a ex-sogra se utilizavam de suas condições laborais, relacionais (devido ao apoio da família matrilinear), assim como o auxílio do programa de transferência de renda, Bolsa Família, para sustentarem o posicionamento em relação à família que as convieram.

No capítulo V, Grupo de Família, utilizarei situações trazidas em um grupo de família composto majoritariamente por mulheres cujo a maioria delas trabalhava fora de casa e com carteira assinada e usavam seu dinheiro com a família e principalmente com elas - produtos de beleza, entretenimento, entre outros. Os maridos aceitam dividir as tarefas de casa e eles o fazem, em alguma medida. Ao mesmo tempo elas eram responsáveis pela maior parte das tarefas domésticas enquanto os maridos executavam apenas parte delas. O único pai que participou foi considerado pelos técnicos "perdido", disse não saber ao certo o que fazer "já que as coisas mudaram muito, não fui criado assim”.

Trarei também cenas de outros grupos familiares que versam sobre os lugares da mulher e do homem na família. Problematizarei esses achados.

No capítulo VI, Considerações, traçarei algumas considerações sobre aspectos relevantes da pesquisa como um todo, como a situação das mulheres fortes, a renegociação de funções dentro da dinâmica familiar, e a possível emancipação feminina.

$$
* * *
$$

Antes de entrar no próximo capítulo, explicitarei, a título de evitar mal entendidos, sob que aspectos abordarei o tema família.

Inicialmente, não devemos confundir unidade doméstica com sistema familiar. A primeira é caracterizada por uma imagem momentânea do grupo, muito utilizada em estudos que se propõem a visitas únicas ou entrevistas pontuais, como as do censo. Para uma análise mais complexa esta não se sustenta, pois as populações pobres brasileiras encontram-se em constante mudança, e em curtos espaços de tempo - por vezes, em meses - a composição familiar pode mudar completamente (Bacelar, 1982; Bilac, 1978). Com isso, para abarcar tais mudanças, devemos trabalhar com a segunda noção, pois o sistema familiar foca exatamente no como se dá o processo de trocas de categorias, unidades e lugares dentro da família (Fonseca, 2004).

Dessa maneira, não nos aventuraremos a classificar grupos familiares sob óticas únicas que, 
invariavelmente, resultam em construções de modelos fixos ou ideais que pouco ou nada dizem sobre a família. Seguindo esse caminho, no fim da década de 70 e início da de 80 , surgem autores nas Ciências Sociais, como Fausto Neto (1982), que pautam suas concepções de família em estratégias de sobrevivência, por exemplo. Mas, esse tipo de abordagem acaba caindo em um reducionismo econômico que tenta explicar formas de convivência em grupos de baixa renda por meio de suas adaptações a condições de extrema pobreza (Couto, 2005). Essa visão

corre constantemente o risco de um funcionalismo simplista que reduz o comportamento dos "pobres" à dimensão utilitarista. Parece ter como pressuposto implícito a naturalidade da unidade conjugal (como se não fosse ela também uma "estratégia de sobrevivência") em oposição à funcionalidade da unidade mãelfilhos (como se não fosse ela também o produto de um conjunto historicamente determinado de opções culturais) (Fonseca, 2004, p.59, grifos da autora).

A abordagem realizada levará em conta os aspectos psicossociais (Mandelbaum, 2010; Mello, 2002), entendendo a família como uma instituição social que introduz os sujeitos na vida organizada da sociedade, responsável por transmitir práticas, tais como modos de pensar, se relacionar, desejar, de entender a si e o mundo. Ou seja, é certa caixa de ressonância do mundo em que o indivíduo está necessariamente inserido. 


\section{Capítulo II}

As Mulheres

Eu: Que tatuagem é essa, Gustavo?

Ele: Ué, o nome da minha mãe.

Elis: Falei pra ele não fazer, é feio, mas ele é teimoso... (olha para ofilho com sorriso no canto da boca).

Gustavo é o terceiro filho de cinco irmãos, todos de pais diferentes. Com 17 anos incompletos, tímido, comparece ao serviço pela primeira vez junto de sua mãe. Esta falante e de aparência jovial, questiona e se interessa pelas informações dadas durante o primeiro atendimento mais que o filho, que se limita a dizer, algumas vezes, que só quer cumprir tudo o que for necessário para não dar mais trabalho a ela. "Ele sabe, se acontecer de novo [cometer nova infração], eu largo ele lá e nunca mais volto”, repetiu pela terceira vez a mãe referindo-se aos nove meses anteriores que o adolescente passara na Fundação Casa, preso por roubo de residência. Cumpriria mais seis, agora em meio aberto, em Liberdade Assistida.

Na casa moram, além do adolescente, os irmãos e a mãe, duas tias, o marido de uma delas, um tio e cinco primos; todos os parentes são relativos à família da mãe. Elis conta que Gustavo começou a ter problemas de disciplina quando a avó (mãe de Elis), Edite, morreu. Ele era muito apegado a ela, e segundo a mãe, a morte dela desencadeou o mau comportamento do filho. Edite era vista como uma pessoa "forte", muito importante para o histórico familiar. Antes moradora de rua, só saiu da mendicância quando teve dinheiro suficiente para comprar o próprio terreno, onde construiria sua casa. Elis era criança na época, mas lembra bem de como a mãe se empenhou orgulhosamente nessa tarefa. A avó de Gustavo tornara-se uma espécie de líder familiar, organizando as tarefas de casa e exigindo atitudes de todos em prol do grupo (estudar, trabalhar...).

Nos atendimentos individuais Gustavo pouco se colocava. Apresentava indiferença ao realizar alguma atividade externa, escolher algum tipo de curso ou indicar preferência de horário para o atendimento. Gostava muito da avó, foi uma grande perda, mas não queria falar sobre isso. Expressava-se quando relatava os maus tratos sofridos quando interno na Fundação Casa, tinha pavor do lugar, a comida era ruim, os colchões inexistiam e frequentemente era vítima do abuso de autoridade por parte dos profissionais. Um dos maiores sofrimentos, no entanto, era ver a mãe visitá-lo em um local tão degradante, dava muita vergonha; por isso tatuou o nome dela no antebraço direito logo quando liberto, para homenageá-la, para pactuar que ela não mais o veria 
naquela situação.

Comparecia assiduamente ao serviço. Certa vez, justificou orgulhoso uma ausência, dizendo que um temporal havia atingido sua casa, provocando danos significativos. Teve, então, que ajudar a reparar. Foi um dia inteiro tirando barro do cômodo onde sua mãe e os dois irmãos mais novos dormiam - um verdadeiro mutirão familiar para reconstruir a casa.

Dois meses após o ocorrido, já próximo de concluir sua medida socioeducativa, Gustavo passa a se ausentar do serviço sem oferecer explicações. Após muitas tentativas de contato sem sucesso, Elis liga ao MSE dizendo que tinha acontecido uma confusão em sua casa e que gostaria de vir conversar.

Ao chegar, diz que foi expulsa pela família de sua própria casa. Ela e os filhos mais velhos, Gislene, 20 anos, Wander, 18 anos e Gustavo frequentam a igreja evangélica (os outros filhos são Alessandro, 14 anos e Nando, 10), e lá possuem um círculo de amizades. Elis acabou se envolvendo amorosamente com Dilan, 20 anos, amigo de Gustavo. Mantinha uma relação de amizade com o jovem, eram muito próximos, e os filhos até brincavam que os dois tinham um caso. A brincadeira, entretanto, tornou-se real. Quando estava decidindo como contaria aos filhos, Gislene descobriu e, junto de Wander, Gustavo e Taís (30 anos, irmã mais nova de Elis), expulsaram Elis de casa. Esta relatou que não conseguiu nem conversar, pois eles, aos berros, não a deixaram entrar, e com a roupa do corpo teve que ir embora.

Estava desesperada, ria nervosamente, indignada por nem lhe darem a chance de explicar. $\mathrm{O}$ que a deixava mais triste era o fato de a irmã ter ameaçado de processá-la por "abandono de incapazes". Essa expressão foi utilizada diversas vezes por Elis para comunicar sua indignação com a atitude de Taís, pois estava incrédula, trabalhou durante anos para sustentar os filhos, e agora ser acusada de abandoná-los? Elis adotou, então, uma postura de tranquilidade aparente diante da ameaça, relatou não se importar com o resultado do processo, pois sabe que foi boa mãe e que ninguém poderia provar o contrário.

Decido entrar em contato com a família. Gustavo atende o telefone e fala que a mãe não foi expulsa, ela escolheu ficar com o namorado diante da decisão da família de não querer que Dilan viesse morar com eles. Disse sentir falta da mãe, não queria que a situação estivesse daquela maneira, estava até arranjando alguns bicos para aliviar as despesas de casa - algo que Elis sempre quis que ele fizesse.

Agendamos a visita domiciliar. A casa possuía um grande quintal e três pequenas construções dispostas em semicírculo em volta dele. A primeira era a maior, onde se localizava a sala/cozinha e, separados por um tapume, dois quartos interligados; em um deles dormiam Taís e o 
marido, Jorge, e no outro os dois filhos, um de 11 anos e a outra de nove. Na segunda construção, um pouco menor, havia dois quartos, em um deles dormiam Elis e os filhos menores (Alessandro e Nando) e no outro Gislene, Wander e Gustavo. A última construção era bem pequena, a mais danificada pelo temporal, lá morava o tio. Havia mais uma tia de Gustavo que tinha chegado do Nordeste fazia alguns meses com as três filhas, uma de 17, outra de 13 e a menor de 12 anos; todas dormiam na sala.

Eu e um técnico do serviço de medida socioeducativa chegamos para a visita e logo quando entramos passou por mim um homem. Eu o cumprimentei e ele passou sorrindo, meio envergonhado. Perguntei quem ele era, e Taís (quem se ocupou de nos mostrar a casa) respondeu que era o tio do Gustavo e se apressou em nos levar até a sala. Questionei o motivo dele não participar da visita, e ela respondeu que ele tinha muita coisa pra fazer, que ia procurar emprego, provavelmente. Ela achava que ele não sabia que viríamos. Após nos mostrar a casa, eu e o técnico sentamos no sofá da sala e ouvimos as críticas em relação à saída de Elis.

Enquanto Taís, em pé e com um semblante muito cansado, discursava sobre o absurdo que é uma mãe abandonar os filhos, notei algo interessante. Todas as mulheres, sete ao todo, estavam dispostas em nossa frente, enquanto todos os homens presentes, seis, encontravam-se atrás do sofá.

Praticamente só Taís falou. Apontou que não foi a primeira vez que Elis foi irresponsável em relação à família: ela estava contribuindo pouco financeiramente em casa, usava seu dinheiro para uso próprio, era ausente e não se preocupava com Gustavo. Relatou que certa vez, quando criança, o adolescente se machucou brincando, cortou a testa, todos se mobilizaram para ajudar, levaram ao hospital e ficaram com ele durante o período em que estava sendo realizado o procedimento médico. Quando a mãe chegou do trabalho, horas depois, ao hospital, pareceu não ter se preocupado; verificou o machucado, deu um beijo na testa do garoto e riu, dizendo: "eee menino levado!”. "Não é um absurdo?” Indagou-nos Taís.

Enquanto conversávamos, Gustavo estava aparentemente tranquilo, e concordava inclusive com os comentários ofensivos a Elis, chamando-a de irresponsável e rejeitando a ação da mãe. Gislene, a filha mais velha, parecia muito angustiada; quando chegamos, ela estava nervosa, descontente, permaneceu lavando a louça durante toda a conversa, no entanto, ocupava um espaço de destaque na roda, ao lado da tia (lembrando, era uma sala/cozinha). Um fato curioso ocorreu no único momento em que um homem tentou manifestar sua opinião (que não fosse somente breves assertivas corroboradoras do discurso de Taís). Ao explicar como se deu a saída de Elis, em uma das primeiras frases, Jorge - sempre com o capacete na mão, é motoboy - , marido de Taís, gaguejou ao tentar se colocar. Todos, então, deram muita risada, o que causou não descontração, mas 
constrangimento, a ponto dele sentir-se envergonhado e não querer mais terminar seu raciocínio, mesmo com a insistência do técnico em incentivá-lo.

Ao final da visita, já no quintal, Taís e Gislene se aproximaram para conversar reservadamente. Gislene fez coro com a opinião da tia sobre a mãe; falou também da dificuldade de se conseguir um emprego, mesmo sendo ela a mais qualificada dos irmãos (possui alguns cursos profissionalizantes). Taís comentou sobre os pais dos filhos de Elis: "Nenhum deles presta, todos são ou traficantes ou drogados, vagabundos mesmo; o pai do Gustavo parece que morreu faz alguns dias, morava por aqui perto”. Era a primeira vez que eu recebia notícia sobre o pai do Gustavo. Perguntei se eles pagavam pensão e após resposta negativa das duas, comecei a explicar os trâmites burocráticos para conseguir o benefício. No entanto, no meio de minha explicação elas me interromperam, falando que era trabalho demais, prefeririam ficar sem. Por fim, tia e sobrinha contaram emocionadas a história de vida da avó - não sabiam por que a família tinha chegado naquela situação de desunião.

Gustavo compareceu ao atendimento seguinte com uma postura totalmente diferente da visita domiciliar: chorou a ausência da mãe. Não queria que ela se envolvesse com Dilan, mas se não tivesse alternativa ele poderia aceitar o relacionamento, desde que a mãe voltasse.

Chamei para o atendimento seguinte todos da família que pudessem vir, compareceu somente Taís. Relatou a dificuldade dela e do companheiro serem os principais chefes da família. Reforçou que não expulsou Elis, que queria somente que ela se responsabilizasse pela situação: mesmo que escolhesse morar fora, que pelo menos desse atenção aos filhos, pois, apesar da situação financeira ser muito ruim, a principal dificuldade de Taís era cuidar dos filhos da irmã, dar limites. Gislene está estressada, Nando não fala sobre a ausência materna, Alessandro começou a dar trabalho na escola, Gustavo não está mais trabalhando e está se relacionando com pessoas ligadas ao tráfico de drogas.

Novo atendimento destinado a todos e neste somente Taís e Elis estavam presentes. Era a primeira vez que estavam juntas após a briga. Taís falou do caos em que se encontrava a casa, principalmente devido aos filhos de Elis, que não a respeitavam mais. Gustavo já estava no mundo do crime. Elis lamentava e dizia ter feito sua escolha: durante 10 anos não se relacionara com ninguém, não tinha uma vida própria, hoje trabalhava e recebia o auxílio do Bolsa Família, sentia-se na condição de, agora, poder decidir ficar com Dilan. Queria participar mais da vida dos filhos, se disponibilizou a ligar mais e, assim que conseguisse um lugar maior para viver, levaria os filhos consigo. Comentou que se preocupava mais com Nando, Alessandro e Gustavo por serem menores de idade, e que os outros já eram maiores e, portanto, tinham condições de entender sua escolha. 
Taís reforçou que, apesar de gostar dos meninos, ela e Gislene não tinham condições de educar todos e, por isso, não retiraria o processo que abriu contra a irmã, de abandono de incapazes, relacionado aos filhos menores. Elis não contestou, disse que confia que é boa mãe e que nada provará o contrário.

No atendimento seguinte, uma semana depois, Elis chegou primeiro e foi logo contando que tinha se mudado para uma casa pequena junto com Dilan e Nando. Comentou que o filho não estava se adaptando muito bem, pois passava boa parte do dia sozinho, tinha dificuldades na relação com Dilan e queria a mãe mais próxima. Certo dia, Elis chegou em casa e o filho não estava; soube que o menino havia saído sozinho e voltado a pé para sua antiga casa, local muito distante de onde estava morando. Não sabia como o filho, de apenas 10 anos, tinha conseguido fazer aquilo, ainda mais sem dinheiro.

Taís chegou quase no final do atendimento, aparentemente muito cansada do trabalho, e discutiu com Elis sobre o comportamento de Gustavo: “ele está muito violento ultimamente”. E, em tom de desabafo, falou que nunca desejara tanto que sua mãe estivesse viva, se assim fosse não teriam esses problemas. Neste momento, já muito tempo depois do horário de expediente do MSE, Gustavo surpreendentemente apareceu na porta do serviço. Nervoso, sentou ao lado da mãe e pediu pra ela voltar, disse que a casa estava perdendo o controle - Gislene chata, Wander ausente, Alessandro brigando na escola e Nando triste.

Taís se colocava, falou que estava fazendo o seu máximo, que era muita gente para cuidar sozinha, que todos tinham que colaborar, especialmente Gustavo, que estava desrespeitando-a de forma violenta. $\mathrm{O}$ adolescente então chorou, disse que ela não era sua mãe e que a partir daquele momento não iria mais respeitá-la, daria satisfação somente a Elis.

Após esse encontro, Gustavo e Elis não entraram em contato com o serviço, nem responderam às ligações. Somente Taís informou que o adolescente estava vivendo no cômodo em que Elis dormia, não tinha notícias dele e não mais se responsabilizaria; dali em diante cuidaria somente de seus filhos e daria um apoio aos demais.

Meses depois, durante uma conversa informal com um dos técnicos (eu já como exprofissional do serviço), recebi a notícia de que Gustavo quase faleceu baleado por policiais, enquanto roubava um estabelecimento comercial. Encontrava-se, naquele momento, interno na Fundação Casa. 


\section{Mulheres no comando}

Acompanhei essa família durante pouco mais de seis meses, o que me permitiu acessar muito mais do que aqui descrito. Mas, uma das características marcantes no caso descrito é a influência da avó. Ela aparece como uma espécie de fundadora da família, mulher que experimentou uma situação de grande miséria e, com suas próprias forças, a superou, oferecendo condições para a família se constituir. "Forte”, segundo Elis, a avó era quem mantinha a família coesa, ditando as regras e, quando faleceu, o grupo pareceu se "desorganizar". Gustavo começou a roubar. Taís e Gislene também contaram, na visita domiciliar, a história da avó, enaltecendo-a, e em seguida disseram não saber a razão da família estar em desunião. Ligaram esses dois fatos espontaneamente, talvez já fantasiando perguntas difíceis de responder. Será que a família não consegue se sustentar sem Edite? Será que não somos fortes o suficiente para mantê-la unida? Sentem carregar um peso que fica sobre os ombros somente das duas. As críticas de Taís e do grupo a Elis durante a visita eram, em sua maioria, direcionadas às consequências da saída desta comportamentos "rebeldes" dos mais novos, tarefas domésticas antes realizadas por Elis e agora deixadas de lado -, mas muito diziam sobre a saída em si, vivida como um abandono da filha mais velha de Edite.

Como em um matriarcado, em que o comando passa das mais velhas às mais novas, de Edite para Elis, depois a Taís, e mais tarde, possivelmente, a Gislene, a família pouco compartilha as responsabilidades e se desorganiza quando a liderança não se desempenha satisfatoriamente. Lembremos que a tarefa mais difícil de realizar na dinâmica familiar, segundo Taís, era, "sozinha, dar limites [aos filhos de Elis]”.

Fez-se uma roda durante a visita domiciliar a fim de discutir "o problema familiar". Taís e Gislene foram as únicas em pé, se colocando à frente junto com as outras mulheres, enquanto os homens estavam atrás. Taís discursava, todos concordavam. Não havia trocas de opiniões ou novas informações.

No único momento em que o discurso poderia ser diferente, realizado por um homem, este foi ridicularizado. Gaguejou. As risadas tiveram um efeito de descontração, mas uma função castradora, pois mesmo quando incentivado pelo técnico a continuar, preferiu encerrar a sua nãofala, deixar como está. Gaguejar pode ser visto como hesitar em falar, tentar se comunicar com dificuldade, repetindo sílabas sem significado completo. É o que aconteceu também com Gustavo, que repetiu o discurso de Taís com veemência sem que estivesse de acordo com aquilo que 
realmente sentia. Condenou a mãe em um dia, junto da família, e no outro, sozinho, chorou sua falta, querendo-a de volta. Os homens parecem não ter voz, espaço para se colocar, como o tio que passou sem oferecer uma palavra. Gislene, após a roda de conversa, entretanto, não sentiu essa dificuldade e junto da tia veio conversar sobre sua situação.

Jorge sentiu vergonha quando tentou falar, assim como o tio ao sair para procurar emprego senti que estava com vergonha, pois olhava para baixo, com um sorriso um pouco sem graça - e Gustavo quando sua mãe o visitava na Fundação Casa. Não tive condições de verificar especificamente o motivo de cada um, mas é relevante notar como esse sentimento é presente nas figuras masculinas.

Cláudia Fonseca (2004) traz o conceito de honra como um elemento simbólico essencial que regula comportamentos e define identidades dos membros de um grupo, que molda atitudes e autoimagens dentro das normas em que esses membros vivem. Para os jovens do gênero masculino, a honra está relacionada com a bravura, com a virilidade, isto é, com a coragem para matar um adversário, ajudar um companheiro em perigo, resistir à tortura ou escapar heroicamente de ser capturado pela polícia.

No caso de Gustavo, ser pego pela polícia e reconhecido por sua mãe nessa condição constituiu-se como motivo de vergonha, ou seja, de ultraje à sua honra e virilidade.

Para Barbosa (1998), os homens são culturalmente incentivados, desde pequenos, a não expressarem suas emoções. Segundo a autora, virilidade e masculinidade se definem pelo controle, seja emocional, físico, econômico ou social. Isso nos ajuda a pensar que Jorge, sendo ridicularizado pela família ao gaguejar, teve seu controle emocional comprometido. Talvez já tivesse antes, e este descontrole fosse expresso no gaguejar. Referente ao tio, torna-se mais difícil alguma tentativa de explanação, já que não sabemos ao certo o motivo de sua saída. Supondo que tenha sido para procurar emprego (como Taís havia dito), arrisca-se dizer que ele perdeu um controle historicamente atrelado ao homem, o de provedor financeiro da família.

Há outras repetições que aparecem nesta família e nos ajudarão a entender melhor a sua dinâmica.

Elis diz para Gustavo: "Ele sabe, se acontecer de novo [cometer nova infração], eu largo ele lá e nunca mais volto". Taís aos filhos mais novos de Elis: “Abandono de incapazes”. Gustavo para Elis: “quero cumprir tudo o que for necessário para não dar mais trabalho a ela [mãe]”.

A dinâmica desta família parece circular em torno das mulheres fortes, detentoras dos aspectos positivos, principalmente construídos na figura da avó. Os homens não participam desse lado "forte", é designado a eles o outro lado. Suas opiniões são difíceis de serem expostas, não são 
levados a sério (como as risadas frente ao gaguejar de Jorge) e alguns aspectos negativos são imputados a eles - como os atribuídos aos cinco companheiros de Elis, resumidos como traficantes, drogados ou vagabundos. Gustavo rouba. Surge a vergonha entre os homens. Criam-se lugares velados a partir dos gêneros. Os que não estão entre os citados são os filhos menores, aqueles que foram chamados por Taís de incapazes ${ }^{8}$.

Os homens parecem não ter o que falar ou escolher, somente o que fazer e fazer aquilo que lhes era dito, como se algo da simbolização não fosse acessível a eles.

Gustavo repetia o que era falado na discussão familiar durante a medida socioeducativa: não conseguia se decidir por nenhuma atividade específica - cursos profissionalizantes, participação em grupos de adolescentes, visitas às instituições culturais -, e nos atendimentos individuais possuía uma postura reclusa, dizendo que estava "tudo bem", implicando-se pouco nas intervenções. Realizava, no entanto, ações como a reconstrução da casa, atitude na qual demostrou estar muito envolvido emocionalmente; e participou da expulsão de Elis da casa. Mas depois a quis de volta.

Jorge não conseguia se colocar, e não o fez quando teve oportunidade; ao carregar com ele sempre o capacete debaixo do braço, deixou transparecer uma importante função sua na família: o trabalho na rua - ao menos uma função que gostaria de ter. Nando, em casa, não verbalizou para mãe que queria ir embora, apenas foi. Alessandro não falava da ausência materna, apenas brigava na escola. O tio, morando no pior lugar da casa, parecia estar à parte da família, não se sabe pra onde foi e não foi me dito nem mesmo seu nome - apenas saiu de casa para fazer alguma coisa, que não se sabe ao certo o que é, aventando-se que vai procurar emprego.

A ação masculina também aparece em sua vertente violenta. Gustavo em relação à tia, quando esta tenta "dar limites" a ele. O único momento em que Wander aparece é expulsando a mãe de casa, junto de Gustavo. Alessandro, depois da saída de Elis, briga frequentemente na escola.

As mulheres, por sua vez, estavam sempre a falar. Taís em casa no comando, Gislene depois da visita domiciliar me procurando para falar da família e do emprego, e Elis presente nos atendimentos desde o início da medida do Gustavo.

8 Este é um termo jurídico que Taís utiliza na ameaça contra Elis, o que chama atenção é o repetido uso dele em detrimento de outros para se referir aos filhos mais novos desta última. 


\section{Mulheres fortes}

Chamei de "mulheres fortes" as figuras femininas da família de Gustavo, pois desde os primeiros contatos com Elis e Taís, ambas se referiam a Edite dessa maneira. Afinal, qual melhor adjetivo oferecer a uma mulher que sai da condição de moradora de rua, analfabeta, com filhos pequenos e, por meio de seus esforços, sozinha, adquire um terreno e uma casa para toda a família?

É grandiosíssimo um feito como este. Ela cuidou dos filhos, ofereceu um espaço para se desenvolverem, e ainda batalhou para obter condições financeiras a ponto de construir uma casa.

Esse modelo não é dos mais fáceis de atingir e sustentar.

Elis trabalhava como empregada doméstica e ainda cuidava de cinco filhos, todos de maridos diferentes, e simplesmente não houve questionamentos sobre a responsabilidade dos pais na criação dos filhos. Nenhum pagava pensão e, além disso, quando se tocava no assunto com elas, não era demonstrado grande interesse em desenvolvê-lo. Eram evidentes as dificuldades financeiras da família, o custo com os filhos, Elis e Taís até desejavam que os pais arcassem com as despesas, mas quando o assunto era levado adiante e existia qualquer empecilho burocrático, rapidamente desistiam. Explicavam que, como eram homens que "não prestavam", não valia a pena prosseguir, correr atrás. Diziam: “damos conta”.

Apresenta-se uma situação na qual os homens, em última instância, podem ou não se responsabilizarem pelos filhos, quase que por acaso. Já as mulheres, não: necessariamente se responsabilizavam pelos filhos e tinham nas mãos a decisão de responsabilizarem os pais. O contato com a família e o cuidado com os filhos praticamente não eram reivindicados deles; excetuando-se por vezes a parte financeira, pois algumas mulheres atendidas pelo serviço deixavam claro que queriam somente receber a pensão alimentícia dos ex-companheiros, e não se importavam com a presença deles.

Para essas mulheres não há a opção de desresponsabilização. Sua posição, além de porta-voz do grupo, aquela que se mobiliza para encontrar caminhos para o bom funcionamento geral da família, é também a de ser responsabilizada pelas funções de mãe, avó, irmã, vide a intensa participação delas nas atividades do serviço.

Na família em questão, eram 16 integrantes, sendo três as figuras de autoridade: Edite, Elis e Taís. O ex-cônjuge de Edite, pai de Elis e Taís nunca foi citado, não sabemos dizer se chegaram a conhecê-lo, nem se é o mesmo para ambas. Elis teve cinco filhos com cinco companheiros, não permanecendo com nenhum deles, que se retiraram do convívio e a vida familiar se manteve. No 
entanto, quando Edite morre acontece a primeira celeuma familiar, e depois, quando Elis decide sair de casa, a situação torna-se quase insustentável.

Poderíamos imaginar que esse panorama derivasse direta e unicamente de uma questão financeira, pois são muitos membros para poucos provedores. Não é o caso. Taís literalmente relatou que o principal problema da casa não era a falta de dinheiro. Não se cobrava isso dos pais das crianças, nem ao menos se lembravam deles. Mesmo quando este ponto foi tocado na visita domiciliar, quem se manifestou (após ter ficado calada durante toda a conversa) foi Gislene. O assunto que ela escolheu para falar com o técnico foi emprego, como encontrar alternativas para prover a casa. Em seguida, espontaneamente, comparou-se aos irmãos dizendo ter melhores condições de ajudar no sustento da família, já que era melhor qualificada profissionalmente do que eles.

Essa comparação foi uma das poucas vezes em que se remeteu aos homens, em uma tentativa de responsabilização. A imagem da posição masculina aqui fica limitada ao trabalho, e acontece em muitos níveis. Há os incapazes (os que não trabalham), há o ignorado (o tio, que não se sabe se trabalha ou vai procurar trabalho), o Gustavo que consegue um emprego, algo que sua mãe sempre quis, mas logo abandona, e Jorge, que ocupa bem o lugar de provedor (mesmo não sendo o único) e se identifica com ele (é motoboy, sempre com o capacete na mão). Contudo, sua função não passa disso, não é lhe dado espaço para se expressar.

Taís havia comentado que a principal dificuldade em seu cotidiano era "dar limites" aos filhos e sobrinhos. Ou seja, podemos entender que seu maior obstáculo em casa era estabelecer e por em prática o funcionamento de certas regras que se mostrassem necessárias junto aos meninos para o convívio familiar. Em nenhum momento nos atendimentos, conversas ou na visita domiciliar os homens (o tio ou o marido, por exemplo) são chamados para ajudar nisso. Na fala de Taís, eles não aparecem como opção para colaborar com essa tarefa - não que precisassem deles por serem homens, pois, antes da morte de Edite e a saída da Elis não havia essa questão. No entanto, responsabilizá-los por essa tarefa seria uma alternativa para dividir funções familiares que poderiam sobrecarregá-las.

Em muitas ações os homens se desresponsabilizam e/ou são desresponsabilizados, o que acaba transferindo para a mulher o peso das urgências familiares. E elas são colocadas em uma posição na qual não há grandes alternativas se não tentar sanar tais urgências. Esforçam-se para isso. Devem ser fortes para trabalhar em casa, fora e criarem os filhos, tal como o modelo ideal de mulher da nossa família: Edite.

A unanimidade de opiniões que os demais têm em relação à avó de Gustavo faz dela a figura 
principal da família. No discurso ela é tida como o eixo familiar. A partir dela se inicia a interação do grupo naquele espaço de convivência, que é a casa. O primeiro senão da família é atribuído à sua morte, a tentativa de reorganização também é delegada a ela quando Taís indica em tom de desabafo que no tempo em que a mãe era viva não havia tantos problemas. É como se houvesse um desejo fantasioso de que a mãe voltasse à vida para resolver a situação, o que indica como ainda a família tenta se reestruturar para superar a morte de Edite.

Esse cenário traz uma espécie de funcionamento com roteiros quase pré-estabelecidos para cada ator. Quando Edite morre, a elaboração do fato para os membros familiares mostra-se muito complicada, e quando Elis sai de casa é designada a ela a obrigação de ficar. Como se fosse uma regra a impossibilidade de cada uma delas se ausentar.

Quando falamos da matrifocalidade e da grande influência da mulher na família, estamos nos referindo a um panorama desses grupos. Cada organização familiar tem sua dinâmica específica e traz características que são peculiares somente a ela. Analisando a família de Gustavo, podemos perceber como determinados comportamentos e questões perpassam gerações e moldam formas de agir.

Para essa reflexão, entenderemos a família como um espaço psíquico de construção de subjetividade no qual o indivíduo, inicialmente inserido no grupo, mobilizará os demais à "tarefa pré-consciente e inconsciente da construção de uma matriz de representações, de imagens e de lembranças que constituem significações previamente filtradas, censuradas e organizadas na transmissão psíquica" (Ruiz Correa, 2000, p.40). Ou seja, é nesse espaço que se dará a transmissão da história do grupo como legado familiar a ser conhecido, digerido e, possivelmente, transformado pelos seus integrantes.

Ainda segundo a autora, duas características têm grande importância na transmissão psíquica e, consequentemente, na formação subjetiva dos integrantes da família: traços de vivências dolorosas vivenciados pelos pais, e censuras e segredos familiares não necessariamente traumáticos ou dolorosos.

A vivência dolorosa (e heroica) de Edite foi transmitida como um grande legado familiar, refletida na configuração presente do grupo. A forma como as mulheres se colocam diante de todos, com a postura de liderança e se comprometendo com quase todas as responsabilidades familiares, por mais difíceis que possam ser, possui grande ligação com a história de Edite.

Ser mulher forte o suficiente para dar conta de todas obrigações e liderar a casa, como a avó de Gustavo, parece ser ponto fundamental para estruturar a organização do grupo como um todo, além de marcar identitariamente a posição feminina nessa família. Como em uma dinastia, a 
liderança passa das mulheres mais velhas às mais novas. Quando Edite falece, Elis toma a frente do grupo, em seguida sai de casa, então é a vez de Taís se encarregar, e quando esta mostra alguma dificuldade, Gislene entra em cena demostrando disposição a colaborar com a responsabilidade financeira.

Sobre os homens havia um silêncio. Seis meses atendendo o Gustavo e foram poucas as palavras destinadas a alguma figura masculina, quase todas referidas aos irmãos em ações cotidianas. Os tios não falavam. Não se sabia ao certo sobre o pai ou avô. Se houve censura ou segredo é difícil dizer, o que há é o não dito.

Janine Puget (2001) relata que o jogo de recordação e esquecimento resulta na produção de uma história. Quando não existem estas ações e o não dito é sistematicamente instalado, conscientemente ou não, instaura-se a representação negativa do que seria uma explicação encobridora muda de algo ameaçador.

No episódio da expulsão, Elis indica que o motivo de sua saída poderia ter sido a não aceitação de todos diante do fato dela, depois de tanto tempo, novamente ter um namorado. Taís deixou claro que ninguém a expulsou, não foi essa a causa. O problema era que o grupo não queria que o namorado ficasse, ela sim poderia permanecer e deveria se responsabilizar pela situação.

Impossível saber o que ocorreu no momento da briga, mas Elis a vivenciou como uma expulsão e Taís como abandono. Talvez a família se viu ameaçada diante da possibilidade real (como aconteceu) da saída prematura de Elis do comando da casa. O grupo parece ter entendido seu namoro não como uma escolha singular que envolve desejos e aspirações pessoais que poderiam ser respeitados, mas como uma fuga de responsabilidades familiares, como se sua obrigação fosse a de gerir um lar ainda muito sensibilizado pela primeira ausência, a morte de Edite. Não houve maiores explicações ou questionamentos do porquê Elis não poderia namorar (se fosse esse o caso) ou Dilan morar com todos.

A situação de Gustavo junto ao MSE tornou-se problemática não pelo ato infracional em si, mas por suas atitudes diante da expulsão da mãe e da morte da avó. As grandes celeumas familiares expostas não passam pelas ausências masculinas, mas pela ameaça de modificação do posicionamento feminino.

A ruptura ou o estiramento de alguns elos significativos desencadeia o crescimento do trabalho psíquico de integração ou transformação dos vínculos intrapsíquicos (Ruiz Correa, 2000). Algumas concepções familiares parecem estar ainda muito cristalizadas, difíceis de serem modificadas. Após todo o imbróglio, Gustavo em atendimento individual aceita, chorando, o 
relacionamento da mãe, desde que ela volte. No último atendimento ele tem a mesma postura, indicando como a família está desorganizada na ausência de Elis. Taís relativiza o que ela tinha chamado de expulsão e quer que a irmã se responsabilize.

Há um padrão de comportamento no qual o lugar feminino está claro, o de organizadora das relações, líder familiar, máxima responsável pelo grupo; enquanto o masculino ainda é um pouco nebuloso, talvez o de provedor secundário, permanecendo à margem das principais decisões e não responsabilizado em muitas ações cotidianas familiares.

A imagem da mulher que transita pelos espaços públicos, privados e sustenta sua família, não vem de Edite, mas de muito antes. Podemos verificar que a imagem da mulher passiva, gentil, amável e reclusa em um ambiente doméstico não condiz exatamente com a realidade de seu posicionamento histórico na família.

A literatura (Freyre, 2004 [1933]; Prado Júnior, 1977; Ogando 2010) nos mostra que desde o período colonial vivíamos sob moldes patriarcais de família na qual a figura do homem era predominante em relação a da mulher. Nesse período, a igreja imputou a ela as obrigações de: "instruir e educar os filhos cristãmente" e "cuidar com diligência das coisas da casa" (Del Priore, 1993).

Apesar do domínio patriarcal, as mulheres, principalmente as pobres, não eram lacônicas. Além de realizar trabalhos relacionados à manutenção da casa, elas prestavam alguns serviços manuais como doceiras, engomadeiras, costureiras, rendeiras e tecelãs. O que não quer dizer que existia uma liberdade inequívoca e que o desempenho das atividades dessas mulheres era fácil. A sociedade estruturada em um sistema patriarcal ainda reproduzia seus ideais (Samara, 2004 [1983]).

Voltando à família de Gustavo, refletindo sobre a dinâmica familiar e levando em consideração as peculiaridades do grupo, o legado e as relações entre os integrantes, podemos notar como as mulheres se esforçavam, e muito, para realizarem a jornada tripla de trabalho.

Ser "forte", dessa forma, mais do que um legado familiar, é uma necessidade dentro de uma matrifocalidade em que os companheiros estão ausentes. Ao desempenhar essa "força" a que se recorre, entretanto, as mulheres costumam pagar um alto preço.

O reflexo disso vem da condição em que elas se encontravam. Taís sempre cansada, atrasada para o atendimento por causa do emprego e queixando-se dos filhos de Elis dentro de casa. Gislene nervosa, angustiada, realizando o trabalho doméstico e pensando em como encontrar um trabalho fora. 
Elis foi a que pareceu um pouco melhor. Seu movimento, apesar de dispendioso, levou-a para uma situação diferente. Saiu de casa e compartilhou outra com Dilan. Ainda assim, estava constantemente trabalhando e mostrava-se muito preocupada ao planejar trazer os outros filhos, além de Nando, para morar consigo - seria difícil, mas estava se empenhando ao máximo para conseguir.

Essas mulheres estavam sempre desgastadas física e emocionalmente, com os semblantes cansados, preocupadas com os horários e temerosas a cada assunto tocado. Evidencia-se essa característica como resultado das muitas obrigações acumuladas nas mãos delas, em detrimento de outras figuras que também deveriam ou poderiam se responsabilizar.

Uma leitura rasa dos relatos delas, que continham afirmações contundentes de não precisarem que eles se responsabilizem, de tomarem a frente de exigir ou não alguns posicionamentos e dizerem: "damos conta", pode trazer a sensação de uma simples escolha deliberada, possessiva, que responsabiliza elas mesmas pela situação difícil em que estão, já que, intencionalmente, não demonstram querer a presença deles. Nota-se que somente elas foram ouvidas, não sabemos quais foram os posicionamentos deles diante desse cenário familiar - não conhecemos as histórias deles. Quer dizer, não sabemos como foram construídas as explicações para que não julgassem necessária a presença dos homens no cuidado da casa e no sustento dos filhos, por exemplo.

O que podemos afirmar, todavia, é que a desresponsabilização masculina, como foi discutida, aparece em um contexto em que essa figura - em especial, a paterna - mostra-se ausente, enfraquecida e pouco conhecida. Não há muitas escolhas para essas mães, irmãs, tias, a não ser se responsabilizarem por toda a situação familiar.

E a insígnia de serem "fortes" vem muito a calhar em uma conjuntura em que frequentemente se encontram sozinhas e com as obrigações que envolvem a manutenção econômica do lar, os afazeres domésticos e a criação dos filhos. Ser forte, se mostrar e se denominar como tal, pode às vezes trazer um pouco de norteamento, segurança e prazer diante de tantas dificuldades diárias.

\section{Sem pai? É por isso que não tem limite!}

Farei um pequeno apontamento a respeito de uma especificidade das famílias atendidas. 
Tratam-se de famílias que têm em sua composição pelo menos um adolescente em conflito com a lei e, em muitos casos, o pai não está presente.

Alguns autores como Menezes \& Brasil (1998); Goldemberg, (1998); Araújo, (2005), utilizam da teoria psicanalítica para tentar estabelecer relações - bastante discutíveis - entre o ato infracional e a constituição familiar do adolescente. Explicarei rapidamente como a psicanálise costuma ser utilizada nesse contexto.

A ausência de um pai simbólico, segundo os autores citados, poderia levar a uma não execução adequada da lei paterna no complexo de Édipo, resultando na ausência castração de sentimentos de onipotência e totalidade e, consequentemente, ao não reconhecimento de limites por parte dos adolescentes. Por isso, eles seriam levados a infracionarem, já que

A falta da entrada da lei paterna no lar é um fator crucial que leva o adolescente a cometer uma infração. Em todos os casos de adolescentes, acompanhados em nossa pesquisa, a respeito das quais abriram-se processos judiciais por alguma infração, um dado foi constante: vivem ainda uma relação dual, ou seja, imaginária em que o terceiro não entrou na constelação familiar. Esses jovens, talvez inconscientemente, arrumaram uma forma de o terceiro entrar, de maneira inadequada, através de infrações, ou seja, a partir do momento que não foi estabelecida a lei interna; em contrapartida fazem surgir a lei externa (Juiz) para interditar a relação dual (Goldenberg, 1998, p.113).

Uma análise como essa corre o risco de cair em um determinismo infantil que exclui fatores fundamentais que influenciam significativamente as atitudes dos adolescentes como, por exemplo, o seu entorno social e cultural. Vejamos.

Gustavo cresceu em uma comunidade do Campo Limpo chamado Morro do Sol, um lugar onde se localiza o centro do crime organizado na região. Quando fui realizar a visita domiciliar, encaminhando-me até o local da residência do garoto, fui parado por quatro jovens empunhando armas de fogo, que questionaram minha presença no local. Mantive insistentemente a calma e relatei o motivo. Conferiram meu crachá do serviço socioeducativo e, por meio de um rádio, um 
deles avisou que eu estava indo até a casa do garoto. Em seguida, chegou a resposta e permitiram que eu subisse.

Comentei com o adolescente sobre esse episódio, e ele relatou que isso é realizado para a própria segurança deles. Disse que praticamente todas as "subidas" de policiais à paisana ou não, não são para coibir o tráfico, mas para procurar e matar pessoas que possivelmente tiveram uma ação violenta contra algum policial. Nessas incursões morrem muitas pessoas, sendo que a maioria delas não possui relação alguma com o crime organizado. Depois de relatar nomes de amigos e conhecidos mortos, ele finaliza: "Fica despreocupado, você naquele momento se encontrou com os nossos policiais; os caras fardados, sim, são os assassinos”.

"No morro, ser negro e pobre não é motivo de humilhação”. Gustavo, negro, disse essa frase quando eu o questionava sobre a razão de sua apatia em participar das atividades do MSE, já que ele nunca mostrava interesse. O jovem relatou que no último Grupo de Adolescentes os amigos dele foram ao Museu do Futebol, na região do Pacaembu, área nobre de São Paulo e contaram que as pessoas os olhavam com desconfiança somente por sua cor de pele e pelo modo como estavam vestidos. Completou: "Se olham assim, dessa maneira, junto de vocês, imagina eu indo procurar um emprego?”. Ele continua, dizendo que no morro - dominado pelo tráfico de drogas - essas situações não acontecem, lá são respeitados.

No baile funk que frequentam eles conseguem se divertir e, de alguma forma, se reconhecem. No entanto, a cultura é a da ostentação - ter roupas de grifes famosas e chegar ao local de carro ou moto conta como um ponto positivo - é ainda muito forte, dentro de uma lógica em que o "ter" torna-se o "ser", o que os pressiona a desejar tais posses.

Relatei rapidamente um pouco sobre o entorno onde o jovem cresceu e vive. Além disso, associado a um contexto de pobreza - ele a mãe e os quatro irmãos dormem em dois cômodos, são mais de dez pessoas vivendo somente com o rendimento mínimo de três - torna-se, dessa forma, no mínimo, apressado e raso imputar o motivo do ato infracional de Gustavo à questões edípicas. E, se nos voltarmos para a família em questão, notaremos que os disparadores aparentes para a ação do adolescente não surgiram devido à ausência paterna.

As atitudes de Gustavo, tanto de roubar pela primeira vez quanto de voltar para o crime organizado, são atribuídas a dois momentos relacionados. O primeiro à morte da avó, e o segundo quando a mãe sinaliza que não voltaria para casa. No momento que Elis se afasta do convívio familiar o adolescente, primeiramente, volta a trabalhar, assim como sua mãe queria; quando é sinalizado que ela não voltaria para casa, Gustavo se associa ao tráfico de drogas novamente - o que 
evidencia a dimensão da influência materna nas atitudes do garoto. Esses fatos vão contra o argumento, baseado numa concepção estreita do papel do pai, de que a ausência dele resultaria em uma propensão à ausência de limites ou regras. Para Gustavo, as experiências desencadeadoras não necessariamente causadoras - do ato infracional foram relativas à avó e à mãe. 


\section{Capítulo III \\ O "homenzinho da casa"}

Eu: Como foi na escola ontem, conseguiu entregar a pesquisa?

Carlos: Ontem não deu pra ir, na verdade não fui essa semana inteira.

Eu: Por quê?

Carlos: Apareceu um bico pra eu fazer à noite.

Eu: Bico de quê?

Carlos: De descarregador de caminhão, no supermercado ali da avenida.

Eu: Mas você já não trabalha no horário comercial, vai trabalhar à noite também? E a escola?

Carlos: A escola espera né.

Eu: Não é muito cansativo trabalhar o dia inteiro numa mecânica e chegar à noite ainda ter que descarregar caminhões?

Carlos: É um pouco, mas fazer o quê? Tem que colocar comida em casa (esboça um sorriso). Eu: E sua irmã mais velha, ela não trabalha também? A Fabiana não recebe o Bolsa Família? Carlos: Trabalha, mas é pouco, é mais para comprar as coisas delas.

A expressão "homenzinho da casa" foi utilizada inúmeras vezes por diversos profissionais do MSE e instituições parceiras, desde a gerente de um CCA (Centro da Criança e do Adolescente) até a enfermeira do hospital mais próximo ao serviço.

Ela era utilizada com tamanha naturalidade que a primeira vez que a ouvi não fiquei à vontade para perguntar sua definição, com receio de parecer muito "um peixe fora d'água". Mais tarde, todavia, a resposta rapidamente se desvelou no cotidiano.

Essa expressão se refere a famílias nas quais a figura masculina de grande relevância não é o homem mais velho da casa, ou o pai, mas o jovem ou o adolescente. O que não quer dizer, necessariamente, que ele seja a figura de maior autoridade da família. Aqui estamos tratando de famílias matrifocais, e, no caso a seguir, essa figura será a mãe, Fabiana.

O jovem pode se encontrar nesse lugar em famílias monoparentais, colocando-se na posição de um dos chefes da família. Pretere os estudos ao trabalho, tem atitude de proteção à família e sente-se corresponsável pela casa, junto de sua mãe . 
O diálogo descrito acima ocorreu já no final da medida do adolescente, fazia alguns meses que seu pai falecera.

Carlos é o segundo de uma família de três filhos - além dele com 17 anos, há duas meninas, uma de 20 anos e outra de 16. Vivem com a mãe, Fabiana, que havia se separado do pai do garoto quando este tinha dez anos. A irmã mais velha trabalha em telemarketing, a mãe é manicure e é beneficiária do programa Bolsa Família.

Carlos é um jovem alto, com um porte físico mais desenvolvido que os demais de sua idade que frequentavam o MSE. Tem uma pequena dificuldade para falar, leve problema de dicção. Está sempre disponível, com um sorriso simpático no rosto é muito difícil ouvi-lo dizer "não".

No primeiro dia que o conheci, durante a Acolhida, sério, mas não sisudo, ele não se furtava a responder pergunta alguma do PIA ao lado de sua mãe. Quando indaguei, no entanto, se já tinha trabalhado alguma vez (uma das questões do PIA), ele e a mãe deram risadas, responderam que sim. Não entendendo o motivo dos risos, prossegui, perguntando quais tinham sido os trabalhos. Ele tomou a palavra: "pedreiro, funileiro, pintor, ajudante de padeiro, balconista, trabalhador de lavarápido, garçom, ajudante de mecânico, feirante...”. No total, 14 empregos. "São muitos, por quê tantos empregos Carlos?", perguntei e ele respondeu, "Sou só eu lá em casa, depois tem minha mãe e minha irmã, claro".

Fabiana conta orgulhosa que todos o conhecem no bairro por ser muito trabalhador e esforçado; adora ajudar os outros. Por ironia, Carlos chegou ao MSE por ter ajudado alguns amigos a venderem cocaína, fato que demostrou ser nenhum tabu, falava disso sem problema algum. Arrependia-se do que tinha feito por ser ilegal, mas não por ter ajudado o amigo.

Durante os atendimentos ele demostrava muito contentamento em falar de quase todos os ofícios. Certa vez passou mais da metade do tempo de um encontro me explicando detalhadamente como se colocava o insulfilme no para-brisa de um carro.

Ao lado de sua pró-atividade para o trabalho, chamava a atenção que o adolescente não conseguia se manter em serviço algum por muito tempo, quase sempre era ele quem pedia as contas. Dizia que enjoava rápido das atividades e não aguentava pessoas muito autoritárias (remetese àquelas que lhe explicavam o ofício, e o faziam, segundo ele, de forma agressiva). O jovem não entendia porque tinha essa característica, desejava não tê-la.

Em atendimentos, Carlos fala de seu pai, Artur. Gostava muito dele. Lembra-se de quando era criança e costumava acompanhá-lo no trabalho. Era pedreiro. Acordava de madrugada e voltava somente à noite. Todos o conheciam na região como uma espécie de "faz tudo" do bairro, pois também era eletricista e marceneiro. A única queixa que os moradores tinham era de seu 
alcoolismo. Quando bebia passava dias sem trabalhar, não terminava obras e permanecia incomunicável.

Carlos conta também que quando seu pai estava embriagado tonava-se outra pessoa. Violento, agredia os filhos e a esposa. Certa vez, tentou agredir Fabiana com uma faca e ele, com nove anos, pegou o ferro de passar roupa e bateu com força na cabeça do pai, que desmaiou imediatamente. "Estava possuído", disse sobre o pai. No ano seguinte a este ocorrido, Artur comunicou, sem oferecer maiores explicações, que iria para o sul do país sem a família, para tentar recomeçar sua vida. Ninguém entendeu a razão dessa atitude, perguntaram o motivo, mas não obtiveram resposta satisfatória alguma. $\mathrm{O}$ adolescente relata que depois disso tiveram poucos contatos telefônicos com ele, mas não sabiam ao certo onde morava, trabalhava ou o que estava fazendo.

Os atendimentos com o jovem seguiram de forma regular, ele sempre muito solícito, alegre, se dispunha a falar de qualquer assunto. Após quatro meses de medida e sete anos com quase nenhuma informação sobre o pai, chega a notícia de que Artur havia falecido havia alguns dias, resultado de um câncer. Apesar do pouco contato após a infância, Carlos mostrou-se muito abalado, chorou em vários atendimentos, principalmente ao relembrar momentos em que o acompanhava ao trabalho. Durante esse período, mudou seu comportamento. De um garoto tranquilo, responsável e pontual, passou a se apresentar bêbado no MSE, em horários diferentes do combinado, se ausentando repetidamente da escola e trabalhando com menos frequência.

Ao longo de cerca de três meses trabalhamos esse luto com o jovem. Ao falar da convivência que tinha com o pai, na época em que ainda morava com ele, relatou alternadamente episódios de violência paterna e de relacionamento saudável. Conversamos também sobre sua semelhança com Artur em trocar muitas vezes de emprego, além da mudança de comportamento após o falecimento. Depois desse período, Carlos voltou a seu comportamento anterior, começou a trabalhar e a se preocupar ainda mais com a família.

No mês do encerramento de sua medida, o adolescente contou que havia agredido o exnamorado da irmã naquele final de semana. Contou que a irmã mais nova tinha terminado o namoro com um rapaz para ficar com outro, e o primeiro reagiu ameaçando agredi-la. Depois de saber que a menina estava grávida (fato que havia sido descoberto há pouco tempo), o ex-namorado foi até a casa dela para concretizar a ameaça, já que desconfiou que o filho não era dele. Carlos, então, interveio e agrediu fortemente o rapaz.

Indaguei se não haveria outro modo para ter resolvido a situação, como conversar, chamar a polícia, ou de alguma forma ter chamado a responsabilidade de cada um pelo que aconteceu. Ele 
então respondeu: "não tem isso não, ninguém banca o machão com a minha irmã; o filho a gente cuida, e ela namora quem ela quiser".

Dias mais tarde, eu e outro técnico realizamos visita domiciliar. Durante o percurso até a casa nos perdemos em meio às numerações da rua que ora diminuíam e ora aumentavam, quase que aleatoriamente. Perdidos, perguntei pela casa de Carlos a um senhor na rua, que rapidamente disse “Ah, o filho da Fabiana, a casa da dona Fabiana?” e me explicou a direção. Encontramos Carlos no caminho, que estava entusiasmado e, durante todo o trajeto até sua casa, nos apontava os estabelecimentos comerciais e os nomes das pessoas com quem trabalhou. Foi cumprimentado por muitas pessoas, o que mostrou que era muito conhecido e querido na região.

Quando chegamos a sua casa, Fabiana e as filhas estavam nos esperando. A mãe do adolescente nos cumprimentou alegremente e em seguida, falante, se desculpou pela situação de Carlos junto ao MSE e iniciou a conversa.

“Olha João, você ficou sabendo que o Carlinhos não está mais indo na escola, né? Então, foi culpa minha, viu? Aquela escola é muito ruim, tinha péssimas companhias lá, não era bom pra ele, por mais que ele gostasse, eu tirei de lá. Aí apareceu o serviço na casa do meu pai, o avô dele tava precisando de ajuda pra reformar o telhado, mandei ele fazer isso pra depois terminar de construir aqui, mas antes disso falei pra ele fazer um bico ali no mercado onde ganha mais, a gente tá precisando de um dinheiro pra acabar essa parede aqui. Por sinal, você acredita que semana passada o dono da loja de construção, ali, duas ruas pra baixo, bateu aqui todo cheio de razão pra cobrar os cimentos que ele me vendeu? Ele veio cheio de banca, falando grosso, achando que ia me intimidar. Mas, olha! Falei mais grosso que ele, mandei vir cobrar na data que combinamos e botei pra correr daqui, vê se pode?! Ele passou maior vergonha, todo mundo viu, tá pensando que ele é o quê?",

Fabiana sempre me pareceu bem tranquila, mas vi que talvez eu pudesse estar enganado. Durante sua fala todos a olhavam em silêncio, parecia admiração. "Mas pode ficar sossegada que hoje eu não vim cobrar nada não, só a visita!”, falei pra descontrair, ela com um sorriso um pouco sem graça foi se acalmando, se desculpou novamente e nos guiou para dentro da casa.

O adolescente e suas irmãs esperavam do lado de fora. Em princípio não entendi o porquê de eles permaneceram lá, mas quando eu e o outro técnico entramos, percebemos o motivo. Deparamonos com um ambiente extremamente pequeno, em três pessoas já não era fácil a locomoção, havia praticamente dois cômodos. Um deles era a sala junto da cozinha, no outro existia um espaço incompletamente dividido pelo banheiro ao meio, havia camas de ambos os lados; eram os quartos. No da direita, duas camas de solteiro onde dormiam as irmãs do jovem, e na esquerda havia uma 
cama de casal, em que dormiam Fabiana e Carlos.

Sentamos no sofá da sala e as irmãs do adolescente também entraram. Fabiana, enquanto preparava um café, apontou o lugar onde estavam os azulejos recém concretados. "Essa parede é Carlinhos quem está fazendo, vamos aumentar a casa para quando meu neto nascer”, diz a mãe, olhando para o filho com um sorriso no rosto. Carlos praticamente não falava, do lado de fora prestava atenção em nós com alguma altivez.

As mulheres, por outro lado, estavam desinibidas, participavam da conversa com fluidez, falaram da escola, da briga com o ex-namorado, elogiaram Carlos por ter defendido a irmã, apesar de ter sido muito agressivo. Comentaram sobre como elas se organizavam para manter a casa em ordem, brincavam umas com as outras, mostraram fotos, riam - em um momento mandaram Carlos buscar pão para acompanhar o café. Este obedeceu. Antes de ele ir, criticaram a construção do cômodo realizada pelo irmão, que concordou com elas, avaliando que realmente precisaria melhorar.

O silêncio do adolescente ante toda aquela conversa me incomodou, mas parecia não incomodá-lo. Algumas vezes tentei trazê-lo ao diálogo, infrutiferamente. Quando o assunto foi "emprego", comentei a grande quantidade dos quais Carlos executou, e chamei-o a falar. Ele se limitou a uma interjeição afirmativa. Elas concordavam com pequenas frases: "É verdade!", "Todos o conhecem aqui por causa disso", "Está sempre atrás de trabalho”. Depois das colocações houve um breve silêncio quebrado por uma das irmãs: "É, mas pena que não pára em nenhum, né?”, “É”, respondeu a mãe, “Ele devia voltar a estudar já já também”. Em seguida o assunto terminou, e a conversa voltou a ficar animada. Momentos depois Fabiana encerrou a conversa e a visita. "Bom, tá na hora da gente ir já, né?”.

Essa visita se realizou logo no final da medida socioeducativa de Carlos, e concomitantemente à minha saída do serviço. $\mathrm{O}$ adolescente cumpriu suas obrigações no serviço e hoje não frequenta mais o MSE.

\section{Filho (homem) deslocando-se de lugar}

No início foi difícil o atendimento de Carlos, tímido, falava pouco, tendia a concordar com tudo o que era proposto, dizia sempre estar tudo bem e nunca tinha novidades. Com o passar do 
tempo isso foi mudando e ele começou a se soltar mais. Falar sobre seus trabalhos anteriores era seu assunto favorito, e também uma boa alternativa para preencher o tempo do atendimento sem entrar em temas difíceis de lidar. Devido às suas características, entretanto, esse ainda era o melhor caminho para nascer trocas interessantes em nossos encontros.

O "como" falava de seus trabalhos nos dava uma boa dimensão do seu significado. Existia prazer em contar sobre os ofícios que realizava, para além da necessidade financeira o trabalho era um espaço no qual ele sentia ser útil. Carlos tinha dificuldade para falar em público por sua timidez e não tinha bom desempenho na escola, mas no trabalho encontrou lugar onde poderia se estabelecer, transitar, se expressar e ser reconhecido na família e no bairro.

O ideário de família tradicional nos moldes do patriarcado, que vimos estar longe do que historicamente acontecia na prática - visto que as mulheres nem sempre eram reclusas e submissas -, funcionava com o pai (patriarca) estabelecendo as regras do funcionamento familiar, provendo a casa enquanto a mãe gerenciava as funções domiciliares, os cuidados com as crianças e suas necessidades. Os filhos, dessa forma, apesar de sofrerem influência decisiva paterna, permaneciam na maior parte do tempo sob a tutela da mãe dentro de casa, mais próxima dela também no que se remete às experiências cotidianas (Salem, 1980). A família de Carlos e Fabiana não se encaixa nessa estrutura, os lugares de cada um dos integrantes do grupo dentro da dinâmica encontram-se diferentes dos acima relacionados.

Muitos autores, dentre eles Bilac (1978), Salem (1980), Zaluar (1994 [1985]), Woortmann (1987), discorreram exemplarmente sobre os papéis e lugares familiares além de suas características dentro do contexto de pobreza no Brasil, chegando a resultados próximos do que seria uma estrutura "tradicional" de família. Para especificar as informações e oferecer uma maior precisão nas articulações que realizarei, esclarecendo mais detalhadamente os meandros da dinâmica apresentada no caso acima, escolherei uma autora de referência para construir as ligações e comparações necessárias sobre esses lugares dentro do âmbito familiar, assim como seus traços simbólicos. O que não quer dizer, obviamente, que me furtarei a utilizar outros autores se assim se mostrarem pertinentes.

Cynthia Andersen Sarti, em seu livro A família como espelho - um estudo sobre a moral dos pobres (2007 [1996]), se ocupou atentamente sobre o assunto dentro de um contexto socioeconômico similar ao vivenciado por mim. Trata-se de uma análise, na década de 90, sobre as famílias de bairros da periferia da cidade de São Paulo (em específico, São Miguel Paulista, zona leste), pobres, onde alguns aspectos das relações familiares eram atravessados pelo início crescente 
do empoderamento da mulher em função do aumento da incorporação ao mercado de trabalho e a possibilidade do maior acesso a métodos contraceptivos, dentre outros fatores. A ordem moral da qual utiliza a autora está vinculada à concepção sociológica de Durkheim de que não existe uma “"essência” boa ou má à ordenação moral que fazem os pobres do mundo social, mas busca compreender qual é a interpretação que os sujeitos envolvidos fazem da sua experiência de vida, expressa em suas normas e valores" (Sarti, 2007 [1996], p.21). Utilizaremos essa obra como referência para estabelecer articulações que possam nos ajudar a entender melhor o funcionamento dessa dinâmica familiar.

Segundo a autora, a ideia de família é estruturada em três peças: a casa, o casamento (homem e mulher) e os filhos. A relação entre esses dois últimos configura-se no vínculo mais significativo para o grupo. A posição dos filhos é situada em uma hierarquia rígida em relação aos pais, aqueles devem respeito a esses, que por sua vez exercem sua autoridade por meio da educação que transmitem. Dos filhos, quando crianças, é esperado somente obediência, e quando jovens, já mais adultos, é esperado o reconhecimento, a ciência e a manifestação de que foram auxiliados durante toda a vida; e a retribuição, em relação a alguma eventual necessidade que os pais possam ter.

Junto aos trabalhadores do grupo, os filhos possuem algumas regalias. Os melhores lugares à mesa, por exemplo, assim como a comida são destinados a eles. À medida que as crianças crescem, elas começam a contribuir com pequenas obrigações familiares, como um simples recado a ser transmitido, para depois se integrarem aos outros membros com atribuições de maior importância, como o próprio trabalho (Sarti, 2007 [1996]).

Ainda em relação aos filhos, outro aspecto interessante diz respeito à possibilidade de uma filha jovem engravidar. Nesse caso, a menina sofre depreciação moral em relação à sua sexualidade, e deve se unir ao pai de seu filho. Se isso não ocorrer, o homem é também depreciado por não honrar com suas obrigações de prover sua mulher, e o pai da menina fica com essa responsabilidade. Caso não haja pai, Sarti, (2007 [1996]) destaca que a jovem deve encontrar maneiras para sustentar a si própria e ao filho para não ter sua reputação manchada, ou seja, aqui $o$ trabalho oferece a mulher a mesma autonomia de um homem/ trabalhador/ provedor .

Na casa é o local onde o projeto de vivência familiar acontece. Nela a função do masculino, em especial o pai de família, está atrelada ao provimento de teto, alimento e respeito, e a "boa autoridade" ocorre quando o homem desempenha essas funções, o que se reflete na obediência dos demais - ou seja, a autoridade paterna está embasada no ganho e na honra como valor moral perante 
os demais. A mulher tem seu lugar na organização do lar e nos afazeres domésticos como dona de casa, e só trabalha fora quando "tem precisão", ela não é destituída da autoridade, mas esta se executa em relação à casa, já a do homem em relação a toda família (Sarti, 2007 [1996]).

A autoridade masculina passa também pela função de mediador da família com o mundo externo, responsável pela respeitabilidade do grupo, enquanto a mulher tem a obrigação de manter a unidade familiar, deixar tudo em seu lugar, além de controlar o dinheiro para que ele seja o suficiente para todas as despesas. Vê-se que a mulher possui autoridade, mas não tanto quanto a do homem, pois o universo familiar compreende o da casa, assim, podemos concluir que há uma relação hierárquica complementar clara onde o homem está acima da mulher (Sarti, 2007 [1996]).

Se o homem, por alguma razão, não reúne condições de exercer sua função de provedor de teto e alimento, segundo a autora, ele fica desmoralizado, afetando a base do respeito não só perante ao grupo, mas também da família em relação ao mundo externo. A mulher, mesmo assumindo e obtendo sucesso na condição de provedora da casa, ainda vê comprometido o status do grupo familiar perante os demais, ou seja, mesmo se ele estiver sem ocupação, desmoralizado e aumentando as despesas, é necessário tê-lo em casa para que a família mantenha o respeito.

Apresentamos alguns parâmetros do que seriam atribuições e lugares dos atores familiares dentro dos achados da autora, que a principio já podemos perceber se mostraram bem diferentes dos encontrados por mim tanto no que foi explanado no capítulo anterior como, verificaremos mais densamente agora, na família de Carlos e Fabiana ${ }^{9}$.

No caso apresentado, em que a matrifocalidade se expressa na medida em que o pai está ausente perenemente ${ }^{10}$, podemos verificar como Carlos se desloca de uma posição "tradicional" de filho ${ }^{11}$ para outra que possui elementos tanto do lugar do filho como também do que seria um pai de família.

O adolescente é extremamente obediente à mãe e às irmãs, acata todas as decisões, quase que infantilmente, sai correndo para buscar o pão quando sua mãe pede, aceita mudar de escola e trabalho, não opina. Realiza bicos e ainda retribui para as necessidades familiares trabalhando na

9 As famílias estudadas por Cynthia Sarti eram compostas com o pai presente (fisicamente), o que não acontece com a família em questão quando foi atendida. No entanto, levaremos isso em conta na utilização das concepções apresentadas pela autora no que diz respeito aos lugares de cada membro familiar. Além disso, vale citar que na família a ser analisada no capítulo seguinte o pai está presente.

10 É pertinente relembrar que a matrifocalidade pode ser exercida independentemente da presença paterna.

11 Como posição "tradicional" de filho, estamos chamando aquela hegemonicamente presente no imaginário social, bastante atrelada a concepções patriarcais de família, em que se espera um pai provedor e filhos sobretudo por ele tutelados. 
sua própria casa e na do avô. Ele realiza, portanto, a função descrita como o de um adulto e a de criança, sendo obediente e retribuindo favores, recebendo os elogios das mulheres.

Porta-se também como “'irmão da mãe', guardião da respeitabilidade de seus consanguíneos" (Sarti, 2007 [1996], p. 76). Seria esperado da irmã, como mãe solteira, que ela se sustentasse sozinha, para que, com isso, fosse digna de respeito e orgulho. No caso do adolescente, ele age como esse "irmão da mãe" ao defender a irmã diante da ameaça de agressão resultante de uma escolha dela, mas não delega a ela a obrigação de sustentar o filho sozinha, e diz: " $a$ gente cuida”, ou seja, a mulher sai do espaço de vulnerabilidade moral que o direito ao prazer sexual produziria, no dever de se responsabilizar sozinha por seu filho, e passa a não sofrer julgamentos morais, pelo menos no âmbito familiar. Carlos se afasta de uma posição paterna quando não exige que a irmã permaneça com o namorado, mesmo este querendo. Ao contrário, apoia a irmã na decisão e volta a se aproximar do lugar de pai quando indica que a proveria. Há aqui uma mudança do lugar feminino, uma maior liberdade de escolha e aceitação diante da família.

Carlos, ao posicionar-se dessa forma, manifestando a vontade de bancar os gastos do filho da irmã e defendê-la, entra também no lugar de provedor de respeito. Porém, ele não é o único. Além da mãe e a irmã mais velha possuírem ganhos financeiros, elas reivindicam o respeito familiar, na cena da venda do cimento contada pela mãe. Fabiana se vê em condições de expulsar o dono da loja de construção sozinha, e o faz, o que não se encaixa na característica de que necessitaria de um homem em casa para ter respeito. Ela tem, e é reconhecida por isso não só dentro de casa, mas fora. Quando fico perdido a caminho da visita domiciliar e pergunto pela casa de Carlos, a referência que me oferecem não é do garoto, mesmo este sendo amplamente conhecido na região, mas a de Fabiana, “Ah (...) a casa da dona Fabiana?”.

Podemos notar que as ações realizadas por cada um dos atores da família não se desempenharam como fórmulas pré-estabelecidas em espaços delimitados teoricamente. Elas aconteceram organicamente, no interior da dinâmica familiar, ou seja, a partir das necessidades, expectativas e vontades daquela família

Verificamos como o lugar de Carlos tende a se descolar, seguindo a concepção de Sarti (2007 [1996]), do homem principal da família (usualmente o pai), mesmo sendo provedor de teto e alimento. A irmã mais nova não trabalha, a outra irmã e a mãe sim. Não sabemos quanto cada uma ganha ou se o adolescente é o que mais recebe na casa. Independente disso, podemos ver dois movimentos. O jovem, durante a conversa inicial, não demostra interesse em especificar o quanto cada uma recebe, mesmo ambas possuindo empregos e sendo auxiliadas pelo Bolsa Família - 
apenas resume que esse dinheiro é "pouco", e se destina "para as coisas delas". Ele teria que sair da escola para ter um segundo emprego, ou seja, coloca-se na responsabilidade de ser o maior provedor. Do outro lado, a mãe também parece o colocar nessa mesma posição quando avaliza a situação laboral do filho, ao alegar que a família precisaria de mais dinheiro. Ele é o eleito para trabalhar ainda mais, não elas.

O jovem, apesar de aparecer como o provedor máximo, não goza da autoridade dessa posição. Ele praticamente não decide questão alguma, ao contrário, decidem por ele, e é constantemente delegado a mais funções. A autoridade "tradicional" da mulher seria a dos afazeres domésticos, em relação à casa. No caso, realmente é. São elas que limpam, põem a mesa, preparam o café, controlam o dinheiro, como faz Fabiana ao calcular que o filho deveria trabalhar mais. Mas, definitivamente, elas não são hierarquicamente inferiores ao homem. Ocorre o contrário.

Sarti (2007 [1996]) expõe que, na ausência de um marido, era comum um parente da família da mãe ocupar a casa como o responsável (principalmente, devido ao respeito) ou então um "filho eleito" (Salem, 1981 apud Sarti, 2007 [1996]). Carlos parece, assim, ser um "filho eleito", mas eleito apenas em algumas atribuições, como ajudar ainda mais no sustento da casa, mas sem que ocupe uma posição hierarquicamente superior à das mulheres da casa, que continuam a trabalhar fora e são as referências tanto para o mundo externo, quanto intra-familiar. Evidencia-se um aspecto importante da matrifocalidade, a mãe/mulher é a pessoa principal do grupo e que detém o maior poder de decisão, as relações acontecem predominantemente com os membros da família da mãe (a casa que Carlos constrói é do pai da Fabiana e o filho da irmã mais nova ficará com ela), assim como as mulheres da família se reúnem para o comando da casa.

A respeito da escola, a mãe decide em qual Carlos estudaria. No trabalho dentro de casa, Fabiana decide quando ajudaria na construção da casa deles e na do avô. No trabalho fora, decide onde poderia ou não trabalhar e quanto ganharia. Vemos aí que as mulheres não têm a responsabilidade de somente fazer render o dinheiro, mas também sobre como ele é ganho. Mais do que tomar decisões e contribuir no sustento da casa, elas criticam o trabalho de Carlos e suas atitudes.

Essa ambivalência entre criticar e elogiar é um fato muito curioso. Gostam que ele trabalhe em casa, mas criticam a construção do cômodo; sentem orgulho dele ser reconhecido pelos vários serviços que realizou na comunidade, mas reclamam que não permanece por longo tempo em emprego algum; Fabiana diz que ele não está estudando por culpa dela, mas ao final da visita, mãe e filha apontam que ele deveria voltar rapidamente aos estudos; elogiam o fato dele ter defendido a 
família no episódio da briga com o ex-namorado da irmã, mas ressalvam que ele foi excessivamente agressivo. Essa dicotomia explicita justamente a dupla face em que se encontra o garoto. Ele é elogiado por fatores que indicam um posicionamento paterno como trabalhar, ser reconhecido na região e proteger a família; ao mesmo tempo em que é criticado como se fosse um filho que ocupa um lugar que não deveria ocupar, devendo ser instruído e educado nas obrigações escolares ou no comportamento agressivo de um adolescente.

O lugar que Carlos ocupa - aliada às características já citadas -, de certa forma, tende também a reatualizar a composição de família nuclear. A mãe olha para ele com orgulho justamente quando ele desempenha uma função "tradicional" paterna, como o de construir o cômodo para a casa, e o coloca nessa posição indicando que ele deve trabalhar. e o mesmo sentimento é por ele expressado quando diz que está trabalhando e tem que trazer o dinheiro para casa.

A união em torno das "mulheres que mandam" não se dá somente através das avaliações práticas, mas no nível de afinidade que têm entre elas. Durante a visita domiciliar, quando sentamos para tomar o café, foi impactante a desenvoltura como conversavam, a liberdade que tinham umas com as outras para falar de qualquer assunto, em alguns minutos o papo já estava em temas dos mais variados. Essa relação é em torno das mulheres, pois quando eu fico incomodado e chamo Carlos a participar, ocorre uma clara interrupção. Instaura-se um silêncio constrangedor momentâneo, a conversa antes criativa e animada passa a ficar resumida em algumas frases sérias e monotemáticas: "É verdade!", “Todos o conhecem aqui por causa disso", "Está sempre atrás de trabalho", como se eu tivesse introduzido um elemento estranho, mas não totalmente indesejável. Reconhecem o mérito de Carlos em trabalhar, disso não se podia duvidar, entretanto era um elemento desconexo a uma engrenagem azeitada que voltou a funcionar quando o assunto mudou. A sala era pequena, ele não caberia no sofá, mas justamente por ser pequena todos estavam muito próximos, e mesmo assim ele permaneceu durante mais ou menos 20 minutos sem falar ou se colocar. Lembrou-me muito a conversa na casa de Gustavo, no caso do capítulo anterior - as mulheres ativas e os homens contraídos.

A relação da família com o mundo externo seria mediada pelo homem da casa. Carlos transita por essa área e a mãe se orgulha disso, assim como demonstra ter satisfação pelo fato dele ter tido vários empregos (como na cena da Acolhida) e de ser conhecido na região inteira. $\mathrm{O}$ adolescente parece ter consciência disso, e fala também com orgulho, como disse de sua agressão ao ex-namorado da irmã como proteção familiar - "ela namora com quem ela quiser". No entanto, 
não podemos afirmar que ele seria o detentor do elo entre a família e o ambiente externo. Como já apontamos, a casa, além da família, é conhecida como sendo de Fabiana, "Ah, o filho da Fabiana (...)”, e as mulheres parecem não necessitar dele para fazer essa mediação. Voltando para o episódio do cimento, a mãe detém condições suficientes para lidar com essa questão e ser reconhecida moralmente por isso quando afirma seu lugar no bairro perante os vizinhos e o comércio, ao exigir que o dono da venda não continuasse com a atitude desrespeitosa, "Falei mais grosso que ele", "ele passou a maior vergonha", "todo mundo viu”. A vergonha não está com ela, mas com o dono da loja de construção, que invadiu seu lugar. "Ele tá pensando que é o quê??" para ele entrar tem que vir "no dia combinado”. Ela delimita publicamente seu espaço e o da família.

Carlos oscila entre os lugares de pai, filho e irmão, desempenha as funções "tradicionais" de cada um, colocando-se nessas posições, entretanto não usufrui da autoridade condizente destes lugares.

O jovem não possui força de decisão junto à família, não parece ser desonra para ele a irmã escolher o namorado e não trabalhar para sustentar o filho. Parece ser o provedor máximo da casa (apresentando-se nessa posição), todavia é obediente. A escola em que estuda, o trabalho que realiza e suas ações na casa são decididos entre as mulheres. O respeito é também exercido por elas, ou seja, a relevância feminina é muito grande na dinâmica, encontram-se hierarquicamente superiores. Invertem-se, assim, os achados de Sarti (2007 [1996]).

O espaço "tradicional" que seria do pai aparece ocupado não somente pelo menino, mas pelas filhas e, principalmente, pela mãe. Esta realiza, juntamente com os filhos, a função provedora de alimento, teto e respeito, e angaria a autoridade máxima familiar.

O mesmo ocorre no caso anterior, pois as mulheres trabalham, assim como os homens (como o marido da Taís e outros que procuravam emprego), mas elas são proeminentes nas decisões familiares (tanto na organização de todos, liderada por Taís, como em sua "desorganização" quando Elis decide viver fora do grupo).

Um lugar que se mostrou ainda apropriado pelos homens é o universo do trabalho. 


\section{O trabalho e o posicionamento masculino}

Antes de adentrarmos à questão do trabalho e ao lugar do homem na família, é relevante contextualizar que o provimento possui contornos de necessidade, para além de compor a dinâmica entre homens e mulheres dentro do grupo. Com isso, ser homem, pobre, dentro de uma família está intimamente relacionado com a identidade de ser trabalhador (Zaluar, 1994 [1985]).

A posição do filho frente ao trabalho, seguindo os estudos de Sarti (2007 [1996]), é a de, se possível, contribuir financeiramente com o sustento da casa. Essa contribuição está alocada no mesmo significado de reconhecimento e retribuição, dessa forma, o filho não tem a obrigação moral de prover a família, mas essa atitude vem como um ganho secundário, uma ajuda, dentro do contexto de precariedade financeira, assim como é o trabalho extra-doméstico da mulher.

A função moral do trabalho para o filho perante a família encontra-se ligada ao seu bom comportamento. Ocupar o adolescente, desta maneira, é um caminho para que ele não fique à mercê de "más companhias" e "influências ruins", usualmente localizadas na rua, espaço não vinculado a boas atividades, tanto que o mesmo discurso é utilizado com as crianças em relação à escola ou outras instituições de ensino. As filhas mulheres têm seu lugar somente no auxílio com os irmãos menores e nas atividades domésticas; a elas o auxílio financeiro não chega a ser cogitado (Sarti 2007 [1996]).

Carlos não se encontra na posição de provedor secundário pelos ganhos que sinaliza ter. Coloca-se na obrigação de provedor principal quando não titubeia em trocar a escola pelo segundo emprego - gosta disso, sorri quando informa o fato a mim, mesmo sabendo claramente que isso pode prejudicá-lo no cumprimento de medida, já que um dos requisitos básicos para que o adolescente possa finalizar a medida é ter regularizada sua matrícula e o comprovante de alta frequência escolar, sem isso o adolescente não pode terminar seu percurso no MSE. Para ele isso não importa, prefere encarar o risco, “fazer o que né?", diz sorrindo. Parece ser prazeroso fazer essa escolha, mostrá-la a mim. Constitui-se um lugar tipicamente de um pai de família, pois a primeira obrigação do filho seria a escola, o reconhecimento e a retribuição moral, depois, se houver a possibilidade, a contribuição financeira.

A família também o coloca nessa posição quando propõe a ele fazer a escolha pelo bico. Não é usual a família realizar tal proposição ao filho, ela exige, antes, os estudos. No entanto, o faz e o aspecto moral aparece justamente em outro momento, no qual a autoridade entra em voga. Para afastar Carlos das "péssimas companhias" evoca-se a autoridade materna, a fim de transferi-lo de 
instituição escolar. Lembrando que Fabiana faria isso a contragosto do jovem, "por mais que ele gostasse [da antiga escola] ", até surgir a nova oportunidade de emprego. Apesar de não estar entre os filhos no que confere o trabalho - pois, essa função não seria a do filho -, não tem e não exerce o direito de escolha.

Esse poder de influência feminina não condiz com os dividendos simbólicos da condição tradicional de trabalho por elas exercido dentro de uma família. A autoridade da mulher, assim como as expectativas de seus ganhos financeiros em relação ao chefe de família, são secundários. Espera-se dela o sucesso nas atividades domésticas, tais como, passar, cozinhar e limpar, todas elas muito calcadas também na condição maternal de ter que cuidar dos filhos ${ }^{12}$. Se lhe são tolhidas muitas das funções fora de casa, o desempenho dentro teria como consequência pessoal uma grande gratificação (Sarti, 2007 [1996]).

O trabalho fora, na situação de "ter precisão", indica alguma parcela de individualidade para as mulheres, mas ainda assim está referida à dimensão familiar, pois com os seus esforços ela apenas terá um "dinheirinho seu”, e alguma satisfação de, pelo menos, poder sair de casa, mas não um reconhecimento significativo, já que aquela não é a sua função. Com isso, o desemprego não impactaria de maneira significativa a sua identidade familiar. Já para a mãe solteira o fato de estar desempregada possui um sentido parecido com o do homem, uma vez que o trabalho remunerado oferece um aval à mulher para reparar o ato condenável de ter tido um filho em condições inapropriadas, ou seja, sem um pai (Sarti 2007 [1996]).

Durante a visita domiciliar Fabiana afirmou que ela e as filhas eram quem cuidavam das tarefas internas de arrumar a casa, limpar as louças e fazer o café, todavia, em momento algum transpareceu que elas estavam confinadas a esse trabalho ou tinham grande satisfação em realizá-lo. A atitude "pró-ativa" das mulheres, em específico, de Fabiana, era visível em todos os setores. Ela mandou embora o dono da loja de construção, planejou o cômodo para o neto, delegou ocupações, decidiu onde Carlos iria trabalhar, junto das filhas o mandou comprar pão e estas classificaram, como ruim, o trabalho do jovem.

A atividade doméstica parece mais ser uma dentre a gama de ações que envolvem os vários domínios familiares. Não há um prazer especial em executar as tarefas, visto que seu lugar familiar não está restrito à casa; a mãe e a irmã mais velha trabalham, a irmã mais nova estuda e pode se envolver com quem ela quiser. Elas transitam em muitos lugares.

Conforme depreendemos, o ganho financeiro das mulheres tende a ser menor que o de Carlos. Ele apresenta essa situação quando pergunto sobre os rendimentos delas, "Trabalha, mas é

12 Dentre alguns autores, ver: Badinter (1986), sobre a falácia da natureza materna da mulher. 
pouco, é mais pra comprar as coisas delas”. O jovem classifica o ganho das mulheres como sendo voltado "pra comprar as coisas delas", quer dizer, ao falar do trabalho remete-se a uma condição tradicional de as mulheres terem o seu "dinheirinho". No entanto, quando colocado no contexto familiar, talvez o dinheiro, apesar de ser menor em quantidade, não resulta em um menor exercício de autoridade.

A renda obtida pelas mulheres está relacionada à individualidade delas, mas não como aquela descrita por Sarti (2007 [1996]), de uma singularidade ligada à família, mas, associadas a elas mesmas, já que quando a família necessita de mais dinheiro, quem deve obtê-lo é Carlos. Além da profissão, Fabiana ainda recebe o benefício do Bolsa Família, então esse "dinheirinho" encontrase um pouco mais acrescido.

No caso da mãe solteira ser difamada por não trabalhar, isso não ocorre com a irmã mais nova do adolescente. Ela é a única que não trabalha, e não a chamam a isso. Não houve qualquer menção para que ela se responsabilizasse nesse sentido.

Podemos verificar que a situação da mulher na família encontra-se aqui bem diferente no que concerne o trabalho. A autora discorre:

O trabalho da mulher pobre não constitui uma situação nova que forçosamente abale os fundamentos patriarcais da família pobre, porque não desestrutura o lugar de autoridade do homem, que pode se manter, sendo, inclusive, transferido para outros homens da rede familiar (Sarti, 2007 [1996], p.99).

Todas as mulheres adultas na família de Carlos trabalham e detêm a maior autoridade, independentemente de quanto ganham. No caso do capítulo anterior, acontece o mesmo com Taís e Elis, de forma que mesmo Jorge trabalhando, não possui autoridade alguma.

Já para o homem adulto, provedor, o "pai de família" o trabalho ganha outros contornos. Para ele trabalhar não é meramente uma ocupação que traz dividendos materiais, mas uma identidade masculina, que oferece autonomia moral suficiente "que lhe permite dizer: eu sou" (Sarti, 2007 [1996], p. 88, grifo da autora).

A identidade de trabalhador se confunde com a de pobre, pois apesar do homem não possuir bens materiais, ele pelo menos possui a disposição e a fibra de levantar da cama e trabalhar. Iguala- 
se moralmente rico a pobre, porque este tem saúde, força e coragem para fazer o que aquele usualmente não faz. Neste patamar o homem pobre se equipara moralmente a qualquer um. Dentro da família confere-se a ele dignidade e autonomia moral para se exigir o respeito de todos os membros do grupo, resultando na reivindicação de reconhecimento, estabelecendo, assim, de forma concreta sua autoridade (Sarti, 2007 [1996]).

O trabalho em si para o homem pobre, em muitos casos, não tem sentido se não for para sustentar sua família. É fundamental que ele tenha filhos e mulher, sendo um pai de família, para afirmar sua virilidade e masculinidade dentro de casa. Esse papel de provedor, independente do trabalho que executa, está intimamente ligado à sua valoração frente ao grupo; o bom provedor é o bom chefe de família. Não obstante, se o homem passa a beber demais, jogar, se ausentar da família prejudicando essa função, inicia-se um processo em que ele perderá sua autoridade dentro de casa (Sarti, 2007 [1996]).

Alba Zaluar (1994 [1985]), acrescenta a existência de uma certa "ética do provedor" que leva em conta que o trabalho é um meio para a finalidade do provimento. Este status de "ganha pão" é bem vindo entre os adultos, entretanto, entre os jovens, é tido como algo negativo no qual, segundo a autora, estaria vinculado a uma visão escravista do trabalho.

Carlos está inteiramente enredado na posição de provedor. É por meio do trabalho, afinal, que ele junto de sua mãe se apresenta para mim. Apesar do adolescente falar com animação das diversas atividades que já realizou, é indiferente para ele se se encontra como pedreiro, pintor, garçom, ajudante de padeiro, entre outros. O importante é que ele trabalha, não importa onde, nem como ou quando, sobra-lhe disposição para correr até a padaria e comprar o pão, ou saber que depois de fazer o telhado do avô, fará o cômodo de casa e depois irá ao supermercado, “todos o conhecem na rua por isso". Ele ajuda sem distinção, pode até não ter bom desempenho na escola, mas sabe detalhadamente explicar o processo de colocação de um insulfilme preto em um carro. $\mathrm{O}$ trabalho, portanto, o permitiria dizer: eu sou.

Carlos oferece sinais de que está apropriado dessa posição quando diz contente, "tem que colocar comida lá em casa”. E depois quando perguntado dos empregos responde serenamente: "Sou só eu lá em casa, depois têm minha mãe e minha irmã, claro”. Está internalizado para o jovem que seria função dele trazer comida para casa. Somente depois lembra que uma das irmãs e a mãe também trabalham e possuem rendimentos.

Para um jovem o trabalho poderia ter uma conotação negativa, mas não para Carlos, ele tem orgulho disso. O mesmo de um adulto a ser reconhecido dento da família, como fora dela. A maioria dos comerciantes da rua o conhecem, o cumprimentam, gostam dele. 
No momento, entretanto, que há uma exigência emocional forte, como, por exemplo, a morte do pai, essa responsabilização familiar, talvez um amadurecimento, é colocado à prova. Carlos, então, passa a beber e a se atrasar para os atendimentos, atitudes consideradas imaturas, mas não incomuns em adolescentes. Era, todavia, incomum nele, até então.

Para o adolescente pobre em especial, o trabalho está associado ao processo de amadurecimento social e psicológico que o enreda na busca por autonomia e independência. Como em um ritual de passagem, a entrada para o mundo do trabalho (seja este formal ou não) marca a saída de um posicionamento infantil para o posicionamento adulto, com maiores exigências e responsabilidades. O ganho financeiro o atinge de forma a significar espaços conhecidos, imaginados, mas não transitados. Essa apropriação além de oferecer maior autonomia provoca o amadurecimento, principalmente no que se refere à família (Watarai \& Romanelli, 2005).

O filho de Fabiana, mais do que prover a família, via no trabalho uma forma de ser no mundo. Era nítido seu contentamento não só em relatar a importância familiar que tinha pelo fato de levar dinheiro para casa, mas a maneira como isso acontecia. Muitas vezes em atendimentos eu tentava trazer outros temas, como a situação escolar, por exemplo, mas o diálogo não prosseguia. Era de meu conhecimento que ele tinha alguma dificuldade em acompanhar as atividades regulares da instituição de ensino que frequentava (estava no sexto ano do ensino fundamental) e era relevante para o trabalho do técnico saber dessa informação, mas sempre as conversas nesse sentido não ganhavam corpo.

Já em relação aos trabalhos, para me explicar cada ofício, havia uma fala mais entusiasmada e articulada, mais fluida. Lançava outro assunto e voltava a monotonia. Acostumamo-nos, então, a falar dos empregos. Além de ter satisfação em desempenhá-los, o adolescente se remetia a eles como um sinal de maturidade. Comparava-se a outros garotos sempre por essa medida, argumentando como era mais maduro que os demais e estava trilhando o caminho correto para um futuro melhor, justamente por ter o trabalho como atividade cotidiana em sua vida.

Para ele, portanto, o amadurecimento, a construção de um lugar próprio vinha por esse afazer. Não era mais criança, trabalhava e tinha sua autonomia; estava preparado para o futuro, pois como dizia, não era bom nos estudos, nem nos esportes, mas no trabalho e na disposição para realizá-lo ninguém o superava. Estava pronto para assumir o lugar tradicional dos homens pobres dentro da família.

Durante a visita domiciliar, enquanto todos permaneciam dentro de casa, ele estava fora, mas não excluído. Estava tranquilo naquela posição, assim como a mãe e as irmãs em relação a elas 
e a ele. A estranheza, pelo contrário, surgiu quando eu quis trazê-lo para a conversa, aquilo não era o usual, ele ficou constrangido em falar, não dizendo, praticamente, uma frase inteira, enquanto elas, até então animadas no desenvolvimento do diálogo, interromperam o fluxo da conversa delas. A participação dele, portanto, seria a ausência de participação direta dentro daquela dinâmica.

Tania Salem (1980) trata desse papel do homem fora de casa, na rua ${ }^{13}$, onde ele ocupa esse espaço para o provimento e sua relação com a família parte desse lugar, distanciadamente. Quem educa, cuida e se relaciona mais proximamente dos filhos seria a mulher, o homem teria um relacionamento mais longínquo, contudo não menos relevante. Carlos está envolvido com os aspectos de fora da casa, as mulheres de dentro, no entanto, nesse caso, sua influência nas decisões familiares é menos relevante do que a delas.

O adolescente estava fora de casa e olhava com alguma altivez, como quem gostasse da posição. Ao ser solicitado a comprar o pão, sai rapidamente para o cumprimento de uma necessidade que logo se dispôs a satisfazer. Além da gratificação de estar nessa posição e ele também não parece criar entraves para se relacionar com os demais membros da família dessa forma.

Essa "passividade" de Carlos em relação às decisões familiares, ao ser constantemente condescendente com as ações da mãe e das irmãs, receber e realizar ordens sem questionar, foi abalada somente em duas situações familiares: na defesa da irmã contra o ex-namorado e no impacto da notícia sobre a morte do pai.

A forma altiva como o adolescente permanecia frente à casa enquanto eu, o outro técnico e sua família conversavam assemelhava-se muito a uma figura protetora do grupo. Como se vigiasse o meio externo para que nenhum perigo pudesse nos assaltar. Esse comportamento está muito relacionado ao do pai que realiza a mediação da família com o mundo de fora, sendo sua função proteger a família contra qualquer risco que possa haver.

Cláudia Fonseca (2004) descreve muito bem essa função masculina relacionada à tentativa de controle da casa e da família. Esse controle seria a manutenção, pelo homem, dos lugares tradicionais dos filhos e, principalmente, da mulher na família. Quando em sua família, portanto, há sinais de "descontrole", isto indica que ele não está cumprindo com suas obrigações, logo, paira sobre ele o sentimento de desonra (Fonseca, 2004). Exemplo disso seria que os piores insultos dirigidos a eles surgem como "corno", ou seja, incapacidade de controlar sua mulher, e "filho da puta”, em que sua mãe não foi controlada (Scott, 1990).

Na cena da defesa de sua irmã, Carlos sente-se no dever inquestionável de protegê-la contra

13 Para uma melhor apropriação da discussão do espaço da rua relacionado ao homem, e o da casa à mulher ver: Da Matta (1985). 
a ameaça de seu ex-namorado e, sem esperar ordens da mãe ou das irmãs, agride o garoto. Fabiana e as filhas condenam em parte a atitude violenta dele, mas o adolescente, ao contrário do que usualmente acontece, não oferece importância às negativas delas; cumpriu sua função. E, de alguma forma, essa atitude é cabível dentro da dinâmica familiar, pois elas não conseguem criticá-lo totalmente, fazem também menção de satisfação a respeito da atitude do jovem. Elas participam desse contexto.

Diferentemente dos achados de Fonseca (2004), Carlos não relaciona a função de proteção ao exercício de controle familiar. “(...) minha irmã namora quem ela quiser”. Como dito, uma filha grávida, solteira e sem trabalho é motivo de mácula familiar, o homem é desonrado, não cumpriu seu dever. O adolescente não se encaixa no padrão de "pai de família" e no de filho. Protegeu a irmã e não se sentiu desonrado pela atitude dela. Se dermos mais um passo, veremos que, mais uma vez, quando a esfera da função do "pai de família" entra na questão da autoridade familiar, o jovem não se encontra apropriado a exercê-la. É evidente que Carlos pode ter outra concepção sobre a gravidez na adolescência, e avaliar que nessa situação não há necessidade de exercer qualquer tipo de controle. O que chama atenção, no entanto, é que diante da função de proteção familiar ele se sente autorizado a tomar uma decisão mesmo possuindo contornos ambivalentes para a família, visto as opiniões oscilantes delas quando comentaram sobre a agressão do jovem.

Atesta-se também que a "passividade" do adolescente é quebrada somente no que diz respeito à autonomia para a tomada de decisões que atingirão o grupo. Em momento algum ele reprova ou questiona qualquer atitude ou ordem da mãe ou das irmãs, apenas age principalmente embasado em funções tradicionais do homem, de proteger e prover.

\section{Identificação com o pai}

A outra situação em que o adolescente toma decisões que possam ser questionadas pela família ocorreu quando ele recebeu a notícia da morte de seu pai. Carlos passou a beber de forma constante, não respeitando horários no MSE, nem trabalhando com a mesma frequência.

Praticamente não tínhamos falado mais extensamente a respeito de Artur até aquele momento. O que se sabia era muito semelhante ao que os outros meninos do MSE falavam de seus pais e padrastos. Ele não estava presente na família, não havia muito conhecimento sobre sua situação de vida - onde especificamente estava morando ou trabalhava - e, até então, não exercia 
grande influência familiar, não contribuía financeiramente com os filhos, realizando contatos telefônicos de curta duração e esporádicos que, aparentemente, não interferiam na dinâmica familiar.

Um fato que marca a atitude do pai em relação ao grupo foi o modo como ele deixou a família para se mudar para o sul do país. Em um grupo de família, aos sábados, Fabiana contou-me separadamente que não houve motivo aparente algum para essa ação. A família estava estruturada em um funcionamento muito claro, em que ele era o provedor e permanecia na rua trabalhando de manhã até a noite, ela era dona de casa e fazia as unhas de algumas amigas somente para complementar a renda, e os filhos ainda crianças necessitavam de maiores cuidados desempenhados por ela. Fabiana classificava como "normal" sua relação com Artur, apesar dos episódios de violência doméstica.

Segundo ela, nada ocorreu, em especial, por mais que ela tentasse lembrar se tinha feito alguma coisa, para que ele a deixasse sozinha com os filhos de 13, 10 e 9 anos. Fabiana avalia como impressionante a facilidade com que ele cometeu essa atitude após anos de convivência, sem ao menos relatar algum motivo sensato. $\mathrm{O}$ espaço fora de casa como provedor de teto, alimento e respeito só faz sentido para o homem se estiver relacionado à família, dentro de casa (Sarti, 2007 [1996]). Apesar de Artur exercer essa função durante muito tempo, sua relação com o grupo parecia ser muito frágil, a ponto de se excluir até mesmo da função do homem, rompendo totalmente a relação com todos.

Ao longo dos atendimentos realizados no MSE até o falecimento de Artur, a família estava organizada de uma forma que a influência aparente dele era pequena, não se falava sobre Artur e sua presença não era necessária nas atividades cotidianas familiares.

Quando chega a notícia de sua morte, podemos ver que a família se impactou, principalmente no que se refere ao comportamento de Carlos. Mesmo longe, havia uma ligação afetiva e mobilizadora junto ao pai. O vínculo estabelecido entre eles durante a infância ainda se mostrava vivo, apesar da ausência de Artur.

A grande paixão do adolescente era o trabalho. Durante o período de luto ele relembrava em muitos momentos, e de maneira significativa, os bons momentos que tivera ao lado do pai, quando este acordava muito cedo, ainda escuro, vestia sua roupa, e ia trabalhar. Permanecia horas brincando nas construções enquanto seu pai cimentava os tijolos.

A visão que ele tinha sobre o trabalho de Artur era como se fosse de um "pai-herói". Como ele era conhecido na região como um "faz tudo", já que também era eletricista e marceneiro, muitas vezes após o serviço regular ele era chamado pelos próprios moradores vizinhos para resolver 
problemas ligados a essas áreas. Carlos contava essas vivências como se o pai estivesse "salvando" as pessoas das urgências cotidianas.

Certa vez falou sobre um curto circuito inesperado que ameaçava deixar uma família inteira sem energia elétrica durante uma noite, e também sobre o caso de uma parede que desmoronou com a chuva torrencial e seu pai teve que ser chamado de última hora para consertá-la, antes que a chuva molhasse todos os móveis, o que inevitavelmente resultaria em um prejuízo incalculável para aquelas famílias simples. Carlos animava-se com a própria narrativa e dava risadas como se fosse ele o protagonista.

Depois que cresceu parece querer ter assumido esse papel. Mesmo cumprindo medida socioeducativa no MSE, dizia não se arrepender de ter ajudado o amigo a vender drogas. Orgulhase do ambiente que o cerca no bairro onde os moradores e comerciantes não se furtam a chamá-lo a trabalhar em seus estabelecimentos. Tinha um reconhecimento muito semelhante ao do seu pai. Identificava-se com ele.

Entendendo aqui identificação ${ }^{14}$ como

(...) o processo através do qual se assimila um aspecto, um atributo, uma característica, uma imagem, um traço do outro e, segundo esta referência, [o indivíduo] se transforma. A identidade se produz e se refaz através deste processo, ao longo da vida de cada ser humano. Trata-se de um modo de constituição psicológica segundo um outro (Negreiros \& FeresCarneiro, 2004, p. 36).

Dessa forma, podemos verificar a existência de muitos outros atributos e características relacionados ao pai, principalmente no que diz respeito ao trabalho, atividade com a qual o adolescente se identifica e reproduz. A fama que Artur tinha de "faz tudo", sempre alternando em empregos e sendo reconhecido positivamente por ter grande disposição para trabalhar, é similar à de Carlos.

14 Lembrando que na Psicologia, mais especificamente, na Psicanálise há outros conceitos que versam sobre a identificação tais como: Freud (1996 [1921]), Klein (1946) e Chodorow (1990) - algumas dessas obras são trazidas pelas autoras, Negreiros e Feres-Caneiro, no artigo em seguida citado. Seria deveras interessante analisar tanto esse, quanto os outros casos sob esse olhar, no entanto, não nos enveredaremos por essa seara por ser um percurso não condizente com o objetivo aqui proposto. 
Aspectos negativos também emergem neste mesmo funcionamento. $\mathrm{O}$ adolescente, mesmo relatando que gostaria de se estabelecer em um emprego, não consegue fazê-lo, ainda que desempenhe um bom trabalho, é ele quem desiste do emprego, quando permanece por muito tempo. O único senão da comunidade em relação ao seu pai era justamente que, quando se embriagava, não conseguia finalizar as obras que havia começado. Artur não conseguia se manter em uma sequência de trabalhos fixos.

Carlos, quando se encontra em uma situação de tensão emocional e tem que se mobilizar para lidar com a perda do pai, passa a beber como ele e a não cumprir com suas responsabilidades, chega atrasado ao MSE e não executa trabalhos que antes fazia. Encontra nessa posição, semelhante a do pai, uma maneira de conseguir lidar com a adversidade que estava vivendo. Agora não trabalhava tanto e bebia frequentemente.

Quando pergunto do possível comportamento análogo ao do pai, o garoto reconhece e se emociona. Parece ser muito difícil manejar a situação de ter que elaborar o luto de um pai admirado, e se reposicionar dentro de uma família onde presencialmente o pai não estava há muito, entretanto, simbolicamente, parecia exercer ainda relevante influência sobre o adolescente.

Fabiana e as meninas não ficaram incólumes, entretanto mostraram-se mais pragmáticas diante do fato. A mãe de Carlos lamentou rápida e serenamente a perda, mas logo direcionou sua preocupação para as atitudes do adolescente. Sabia que o garoto estava bebendo mais que o habitual e sua conduta diante dos empregos, que tanto gostava, havia se modificado. Conta que o que mais a inquietava era tentar o diálogo, e ser em vão. O adolescente tinha a postura de ouvir a mãe, de não discordar dela, não comentava sobre o ocorrido e continuava com o comportamento que a preocupava.

Em atendimentos, Carlos mantinha-se bastante calado, mas aos poucos conseguiu se expressar um pouco mais. Avaliava como pertinentes os conselhos da mãe, relatava que seria muito bom para ele parar de beber, todavia, repetia essa prática seguidamente.

A influência que Artur exercia sobre Fabiana e as filhas mostrou-se pequena, não houve grandes comoções resultantes de sua morte, já em relação ao filho foi significativa, o que impactou momentaneamente o grupo. Espelhava-se no pai, era identificado com ele. Sua postura em relação à mãe e às irmãs, apesar de suas atitudes recentes de não cumprir exemplarmente com as ordens dadas, parecia não ter se modificado no que concerne ao não questionamento das concepções e condutas delas.

Depois de alguns meses de trabalho com o jovem, Carlos voltou a beber menos e começou a trabalhar como antes. É complicado tentar encontrar uma razão, ou o motivo específico para essa 
mudança, muitos fatores interferem, as ações da mãe, das irmãs, os atendimentos, entre outros. Durante esse ínterim, podemos dizer que o adolescente foi paulatinamente se comportando de forma semelhante ao do começo de sua medida socioeducativa.

Nesse período, Carlos tinha se envolvido na briga com o ex-namorado da irmã. Em atendimento, comentei como ele tinha se munido de uma atitude violenta para defender sua família, no caso, a irmã, e que o mesmo tinha acontecido no episódio da sua mãe em relação ao pai, quando tinha nove anos. Indiquei que em ambas ações, o jovem havia usado a agressividade, questionável ou não, em uma situação de proteção familiar, já Artur, na cena em que pega a faca e parte em direção a Fabiana, a agressividade foi utilizada de uma outra forma. Imediatamente, o adolescente me interrompeu e fez uma ressalva, disse que nesse dia, especificamente, o pai estava muito diferente - "estava possuído". Carlos, em outra atitude protetora, exime o pai de grandes responsabilidades pelo ocorrido.

Podemos perceber, novamente, que Artur, nessa família, não possui pouca influência. Todavia, antes de seu falecimento não se falava muito sobre ele e depois dos poucos meses, que eu classifiquei como o período de luto ${ }^{15}$, Carlos tocava no assunto com naturalidade, e a família não se mobilizava tanto com o fato.

Podemos dizer que Artur foi peça relevante na formação de seu filho, em sua identificação, exercendo certa influência, mesmo quando estava afastado. Sua participação foi, dessa forma, importante no período da infância de Carlos. No entanto, a dinâmica familiar configurada em sua ausência, hoje independe de sua presença.

\section{Trabalho, MSE e relação mãe-filho}

Carlos era reconhecido positivamente na escola, na família, no MSE e no bairro por sua disposição a trabalhar. Estava muito claro para o jovem que por essa atividade se configurava o melhor meio a ser seguido para a constituição de sua família e seu futuro de maneira geral.

Para grande parte dos meninos atendidos no MSE, no entanto, essa relação não era tão simples. O trabalho era visto, ao mesmo tempo, de diferentes maneiras. Se realizado de forma honesta, dentro dos parâmetros legais, era considerado o caminho ideal a ser percorrido. E isso não

15 Para entender melhor a respeito desse processo, sob o viés psicanalítico, é indicado Freud (1917 [1915]). 
somente pelas consequências que poderiam advir da sua não realização, mas principalmente porque é legitimado socialmente como o melhor, o mais correto, aquele em que os dividendos surgem por meio do próprio esforço, ligado com a concepção do trabalhador que tem disposição e saúde para qualquer atividade, que não escolhe serviço, que está comprometido com a responsabilidade de sustentar sua casa de maneira digna, dentro de uma meritocracia aplaudida pela grande maioria da sociedade.

No entanto, esse trabalhador também era visto pelos adolescentes como "zé-povinho "16”, a pessoa que trabalha muito para ganhar pouco, e é passiva diante dessa situação. É explorado por uma sociedade que oferece boas condições sócio-econômicas para poucos e nada para muitos. Com isso, o sucesso financeiro e na vida profissional não depende somente de esforços individuais, pois, além dessa diferença de meios e oportunidades de cada indivíduo, no que diz respeito à escolaridade, saneamento básico, infra-estrutura de lazer e cultura, entre outros, as próprias pessoas que se dizem "direitas", “de bem”, também se beneficiam de pequenas e grande infrações, e passam incólumes a isso. Em nossa sociedade, dependendo da situação em que você se encontra, privilegiada, abastada ou não, há diferentes consequências para os atos.

Todas essas informações - ditas dessa maneira, simples e diretamente - eram passadas a mim pelos próprios adolescentes. É uma visão consideravelmente elaborada, por ter um olhar mais crítico sobre a sua situação.

Em meu primeiro atendimento a um jovem no MSE, eu ainda um pouco nervoso com toda a situação, vi um adolescente, chamado Alberto, de 17 anos "me mandando a real", no mesmo sentido dessa segunda visão acima. Ele me explicou como não surtiria efeito o meu trabalho, nem o esforço dele para que todo o contexto pudesse ser modificado. Assim, duvidava que fosse encontrar algum sentido para se afastar do crime.

Disse que tinha nascido pobre, preto e favelado, seu pai morto pelo crime organizado, sua mãe sempre doente de tanto trabalhar, como garçonete, de segunda a segunda em um bar. Ele não tinha estudo porque teve que trabalhar desde cedo, já com oito anos de idade, e cuidava dos irmãos, uma de dois, e outro de três anos. Como, então, iria se dar bem na vida? O que um técnico de medida socioeducativa falaria a ele para que alguma coisa fosse modificada? E o que ele poderia fazer hoje para mudar de vida?

Semi-analfabeto, ainda no quinto ano do ensino fundamental. Voltaria à escola para estudar com "colegas" de 11 anos - imaginei a cena - ou "estudar" em um supletivo de três horas e meia diárias, à noite, para suprir seis anos de dificuldade escolar em um anos apenas? Como ele sairia

16 Expressões utilizadas pelos garotos. 
preparado para competir por pouquíssimas vagas em um vestibular de universidade pública (afinal, as particulares ele não poderia pagar)?

A solução a ser proposta, portanto - continuou Alberto - seria começar do zero, ser honesto, como todo mundo deve ser. Virar "zé povinho", trabalhar no Mcdonald's (um dos poucos lugares onde ele havia conseguido emprego), ganhar 600 reais pra lavar o chão durante oito horas por dia e ver seu gerente, que ganha somente um pouco mais que ele, fazê-lo diminuir seu horário de almoço, ou seja, ser desonesto, ir contra a lei, para dar mais lucro e ser reconhecido positivamente, como o funcionário do mês. É isso que ele deveria escolher? Seguir o caminho certo, o legal?

$\mathrm{O}$ adolescente prossegue. A mesma lei que serve ao policial militar quando o agride primeiro para perguntar depois, no momento de uma blitz, e usa sua droga enquanto o revista. E, após violências físicas e verbais, intencionalmente, não o leva preso, porque sabe que se ele voltar para casa sem as drogas, os outros traficantes podem matá-lo, pois estes confiaram a ele uma remessa a ser vendida e ao relatar que não as tem mais, não pode provar que foi o policial quem pegou, afinal de contas, não foi preso. No caso do adolescente em questão, ele angariou uma dívida que foi paga após meses de trabalho para o crime organizado.

O que é legal ou não fazer começa a ganhar outros sentidos quando se está nesse contexto. Aqui a entrada para o tráfico de drogas ou em outro tipo de atitude ilegal se transforma em uma alternativa singular. Diminuir o horário de almoço - algo ilegal - é aceitável, já que está trabalhando em uma empresa e está aumentando o lucro. Assim como a violência policial - algo também ilegal -, pois o oficial é o grande representante da lei nas ruas, tem poder para isso, além do mais o jovem não poderia reclamar, afinal de contas, estava portando drogas, um castigo não seria tão ruim.

Borra-se o sentido da lei, afinal, para que serve? A quem serve? E essa questão transfere-se para o cotidiano. A comunidade sozinha se organiza para sanar muitos problemas que seriam função do estado solucionar. E muitas dessas ações acabam provindas do crime organizado, aquele que acaba protegendo e cuidando da comunidade. Esse assunto é extremamente extenso, mereceria uma discussão mais detalhada, mas que não realizarei aqui, pois não é o foco do trabalho.

Trago o tema com a intenção de apenas ressaltar que o estereótipo do menino que frequenta o MSE nem sempre é negativo ${ }^{17}$. Ele é também considerado um menino que sabe lidar com algumas diversidades, que é "zica", ou seja, que tem condições para possuir alguma autonomia financeira por meio de habilidades próprias dentro de uma sociedade que nem sempre é justa com

17 Há também o estereótipo negativo, o de infrator da lei, que discutiremos no capítulo seguinte. 
jovens, negros, moradores de periferia e com baixa escolaridade ${ }^{18}$.

Esse contexto impacta diretamente as relações familiares, principalmente entre mãe e filho. Ela, de maneira geral, não gosta que seu filho seja conhecido como "zica", pois essa expressão, às vezes, pode possuir uma conotação negativa em relação aos meios que foram utilizados para conseguir a autonomia, normalmente fruto de atitudes irregulares. No entanto, é muito desejável que o garoto, por meio de ações legais, consiga essa autonomia, para que ele possa arcar com suas responsabilidades, especialmente as familiares.

Quando os benefícios materiais angariados pelos filhos estão ligados ao resultado de uma infração, algumas famílias costumam emitir um discurso muito semelhante. Falam que todo o dinheiro ganho pelo menino, com essa atitude, é "sujo", e por isso, não entra na casa dela. Se ela perceber algo incomum em relação a isso, que alguma coisa foi comprada com dinheiro ilegal, a ação imediata é devolver o utensílio ou jogá-lo fora, não é importante como entrou em casa.

Seguindo este raciocínio, de alguma forma, o fato do menino roubar ou não, parece às vezes não ser questionado de maneira mais veemente, enquanto que, em relação ao dinheiro, frisa-se contundentemente sua impossibilidade de entrar em casa. Entretanto, devemos salientar não ser incomum essa postura ser culminante com a de uma conjuntura mais avançada de convivência conflitante na qual a mãe se encontra já sem recursos para conversar com o filho, após muitas discussões sem sucesso com ele. Não devemos nos furtar de notar, também, como a separação "casa dela" e "rua dele" é utilizada constantemente como uma espécie de demarcação de espaços e posicionamentos.

Não eram a maioria, mas, frequentemente, muitas mães em atendimentos familiares tinham comigo diálogos como esses:

Mãe 1: Você não sabe João, meu filho está melhorando, ontem chegou em casa à noite com uma pizza grande pra todo mundo, todo bonzinho.

Eu: Você deu dinheiro pra ele?

Mãe 1: Não.

Eu: Ele está trabalhado?

Mãe 1: Não.

Eu: Ele compra fiado em alguma lugar?

Mãe 1: Não.

Eu: Então, com que dinheiro ele comprou isso?

18 A maioria da população carcerária brasileira é composta por jovens, negros ou pardos e com baixa escolaridade, segundo o levantamento da Pastoral Carcerária - www.carcerária.org.br/categoria/publicacoes. 
Mãe 1: Hum... É, né? Não sei.

Eu: Por que você não perguntou pra ele?

Mãe 1: Não sei.

Mãe 2: Esse mês de Dezembro estava sendo muito difícil pra nós. As contas chegando, o Natal, e como não sou registrada [é diarista], não tenho décimo terceiro. Faltava uma conta grande pra pagar, a do mercado onde eu pego fiado, estava atrasada há uns 4 meses. Todos em casa estavam preocupados. E não é que chega no final do mês, e o Jonathan [o filho atendido no MSE] pagou a conta toda?! Com o dinheiro dele! Não trabalhava há anos, aí nesse mês ele arranjou um emprego de entregador de panfletos e com o próprio salário pagou. Era de uns 2000 reis! Agora vamos passar o Natal todos tranquilos!

Eu: Que bom. Mas, quanto ganha, mais ou menos, um entregador de panfletos?

Mãe 2: Ah, não sei.

Eu: Você sabe pra quem ele trabalhou, ou viu ele trabalhando bastante?

Mãe 2: Não. Aí é com ele, né. Mas não vi não.

Eu: 2000 reais são mais de três salários mínimos. Você não acha que é um pouco demais pra um mês de trabalho como entregador de panfletos?

Mãe 2: É... É, né?

Mãe 3: Você precisa ver o Armandinho, como ele é bom em mexer em moto. O quintal lá de casa virou uma oficina, lotada de tanta peça. Todo dia, desde o mês passado, vêm um monte de motos que ele fica desmontando. Tudo dos amigos dele. São umas 10 motos por dia! Ele é muito bom. Na região, todo mundo conhece ele por isso. Muito trabalho. Já até comprou um carrinho pra ele, pra quando fizer 18 anos.

Eu: Ele deve ser muito bom mesmo, mas, você não acha estranho essa quantidade de dinheiro que ele ganhou em tão pouco tempo? Além de ser somente motos de amigos dele?

Mãe 3: Por quê?

Eu: Faça as contas dos dias e das motos, é um fluxo muito grande pra quem acabou de começar um negócio. Assim, parece que todos os adolescentes de Campo Limpo são amigos do seu filho e cada um deve ter umas 3 motos.

Mãe 3: É? 
Eu: Sou psicólogo, não sou muito bom de conta. Mas é estranho seu quintal cheio de peças e você só vê-lo desmontando. Se tiver algo irregular, pode dar problema pra você.

Mãe 3: Nossa, será?

Eu: Não sei se há. É estranho também você, tão cuidadosa, não ter acompanhado isso de perto. É muito dinheiro pra pouco tempo. O que aconteceu?

Mãe 3: Ah, é que aí, são as coisas dele.

Eu: Sim, mas você está tendo que lidar com as consequências de algumas coisas dele nesse exato momento. O que te impede de querer saber das "coisas dele"?

Esses diálogos não eram para averiguá-los, ou ir atrás de algum sinal escuso em suas condutas. Isso, de fato, não me interessava. Mesmo porque, se houvesse algo realmente ilegal acontecendo com algum dos garotos, eu preferiria tentar lidar com a situação a ter que tomar alguma atitude que pudesse transferi-los a destinos que eram reconhecidamente questionáveis, no que diz respeito a qualquer tipo de obtenção de "progresso" no comportamento dele e de sua família. Como, por exemplo, uma possível internação na Fundação CASA.

O intuito dessas conversas era trazer o olhar da mãe às situações que eram nebulosas e que, por alguma razão, ela não tocava ou não notava. A intenção principal não era levar ao conhecimento dela a possibilidade do filho estar cometendo uma nova infração, mas chamá-la a entrar em contato com um cenário que parecia ser evitado. Eu esmiuçava cada meandro desses fatos presentes nos diálogos, sem classificá-los de antemão, para trazer à esfera da consciência situações que, a meu ver, mereceriam ser questionadas para o melhor entendimento da relação que tinha com os filhos.

Por que, de alguma forma, nessas situações, estava difícil conceber, conscientemente, que as ações do filho eram incompatíveis com seus rendimentos? Ou, por que não se questionava simplesmente a fonte de tantos ganhos? ${ }^{19}$ Impossível responder completamente a essas perguntas, cada caso tem as suas razões particulares e complexas que envolvem muitos fatores. Entretanto, em todas as cenas apresentadas, era perceptível que havia, em alguma medida, uma possibilidade fugaz de que aquilo não mereceria ser questionado. Explicando melhor, parecia haver uma abstenção por parte da mãe (por algum motivo não consciente?) em não querer se posicionar de forma crítica diante do fato de que o menino poderia, por exemplo, estar cometendo um ato ilegal, pois, quando eu trazia a situação à baila de forma detalhada, consciente, parecia que ali, pela primeira vez, a

19 Lembrando que todas essas informações eram trazidas voluntariamente, portanto, a chance de ter havido alguma conivência materna era muito pequena. Esses fatos, também, não aconteciam somente em uma família, mas como colocado, em algumas. 
questão ganhava visibilidade. Tanto que, prontamente, surgiam as dúvidas. “É... É, né?”, “Nossa, será?".

As situações trazidas nos exemplos são peculiares o suficiente para que houvesse espaço à dúvida imediata ou ao interesse direto em saber um pouco mais sobre o que estava acontecendo. Eram mães participativas, preocupadas, tanto que vinham a esses atendimentos familiares apesar deles não serem obrigatórios ${ }^{20}$. Estávamos dentro de uma instituição para adolescentes em conflito com a lei e a mãe estava conversando comigo justamente porque seu filho cometeu, ou foi condenado por ter cometido, uma infração. Se a mãe estava também ciente, dessa forma, de que ele não trabalhava e não tinha dinheiro para comprar a pizza, como no exemplo da primeira cena, por que não questionou a respeito?

Os argumentos utilizados por elas, quando indagadas mais a fundo, sobre a razão pela qual não foram mobilizadas a verificar a situação dos filhos, tinham conteúdos semelhantes: "São as coisas dele", "Ai é com ele, né".

Esse movimento apoia-se em uma lógica de que a mãe poderia se eximir de interferir, ou sua função não seria essa, em relação ao modo como o filho ganha seu dinheiro. Os destaques dos discursos, nos casos, foram destinados a outros focos, independente do que os adolescentes fizeram na rua. Um filho pagou a conta do mercado para que todos tivessem o Natal feliz, e não ganhou relevância a informação do quanto recebe um entregador de panfletos. O outro trouxe a pizza para o jantar de família. O terceiro é reconhecidamente bom por seu ofício no mundo externo, todos da região sabem disso; desempenha sua função não dentro, mas no quintal de casa, e lá não se sabe muito bem o que ele faz.

O modelo "tradicional” de família em que os lugares são delimitados - o homem na rua, à procura de provimento, e a mulher em casa - se reatualiza nessas cenas, com matizes positivas. É com alegria que a mãe vem contar que o filho, frequentador do MSE, ou seja, muitas vezes taxado negativamente, trouxe, “bonzinho”, o jantar para casa naquele dia, proporcionando uma situação de bem estar que somente um jantar em família poderia oferecer.

No segundo caso, a mãe relata, orgulhosa, que o filho pagou uma grande conta familiar com o dinheiro dele, fruto do seu trabalho, resultando assim em um Natal tranquilo, sanando a preocupação de todos do grupo. No terceiro, o filho é reconhecido no meio externo por seu trabalho, por sua grande habilidade em consertar motos, algo que até lhe rendeu um fruto valioso, um carro.

Podemos perceber, dessa forma, que a demarcação de lugares por meio desse modelo

20 Pontuando que somente os atendimentos individuais dos adolescentes e determinadas atividades destinadas a eles tinham caráter obrigatório. As únicas presenças exigidas aos familiares eram durante a Acolhida e visita domiciliar. 
familiar é utilizado como um aval reconhecido socialmente para a família transitar em certos assuntos sem precisar tocar em pontos que poderiam ser delicados. É importante que o filho melhore seu comportamento, tenha um emprego, seja reconhecido dentro do bairro por seu ofício, se responsabilize por demandas familiares como o pagamento de dívidas, mas por outro lado, é igualmente importante que tudo seja realizado de forma honesta. Então, como fazer para conciliar ambos os lados em situações como as narradas? As respostas surgem: "Aí é com ele, né”, "São coisas dele”. E não se questiona, mais a fundo, que coisas são essas.

Essas ações das mães não ocorrem de forma deliberada, com o intuito de escamotear algo. $\mathrm{O}$ interlocutor é chamado à conversa na expectativa de que ele compartilhe de uma visão sobre a família na qual o homem cumpre determinadas funções - o de provedor, de estar na rua - e que isso não necessite de maiores explicações.

Quando a mãe, por outro lado, desconfia de que algo estranho aconteceu a respeito dos rendimentos financeiros do filho, conversas como esta costumam ocorrer:

Mãe: Ele comprou tênis novo outra vez, acredita?

Eu: Ah é?

Mãe: Mas ele sabe que aquele tênis não entra em casa, tanto que ele deixa lá na casa do amigo dele.

Eu: E você acha que ele comprou...

Mãe: Com dinheiro de droga? Acho que sim. Não trabalha, não faz nada. Mas já deixei claro pra ele que dinheiro sujo não entra em casa!

Aqui se desconfia que o filho cometeu alguma infração. Reconhece-se essa possibilidade, mas, em primeira instância, a ênfase não se direciona à atitude do garoto de comprar o tênis, nem tampouco é realizada uma crítica mais extensa a esse comportamento. A crítica contundente aparece relacionada a ele trazer dinheiro sujo pra casa. O que ele faz fora fica, momentaneamente, em suspenso. O importante é afirmar e deixar claro que aquele dinheiro não pode entrar. Por um lado a mãe tenta não ser conivente com a situação, mas por outro, não toca, novamente, em fatos claros, como o dinheiro beneficiar o filho fora de casa, o que de alguma forma, alivia nas despesas dentro.

Um detalhe importante é que a autoridade familiar continua sendo a dela. Há a ordem expressa do tênis que ele conseguiu na rua não entrar, e assim acontece. 
Frisando que, com esses exemplos, não quero dizer de forma alguma que essas mães eram coniventes com possíveis atos ilegais dos filhos. Muito longe disso. Todas tinham discursos e posicionamentos extremamente contrários a atitudes como essas, e sofriam muito pelo fato do filho ser reconhecido na região como um infrator.

Devemos, também, nos lembrar de que essas cenas relatadas não fazem parte da maioria das famílias atendidas pelo serviço, mas não são, tampouco, de uma parte insignificativas delas, por isso é preciso discorrer com cuidado sobre essas relações.

A questão trazida versa sobre cenários que possuíam contornos acentuadamente questionáveis, e que não eram percebidos prontamente. Essas situações encontram apoio em um modelo familiar vivido de maneiras singulares por diversas famílias atendidas, onde os meninos podem encontrar dentro da dinâmica um lugar favorável de provedor e não se deparar com grandes entraves nesta escolha. Enquanto as mães só querem o melhor para seus filhos, que eles trabalhem, estudem, tenham responsabilidade e ocupem um bom lugar na família, para que, por exemplo, no futuro, tenham condições de prover seus filhos. Notemos como esse modelo familiar aparece no contexto apresentado, como um cenário onde os atores desempenham suas funções de forma que, para que o todo seja sustentado em coerência, às vezes, é preciso vendar determinados pontos e barrar fatos que, conscientemente, seria melhor se não fossem tocados. 


\section{Capítulo IV}

\section{Sinais da possível emancipação feminina e o lugar do homem}

Ele: Hoje eu quebrei o pau com o meu chefe, xinguei ele e tudo.

Eu: Por quê?

Ele: Ah, sei lá.

Eu: Como assim, André?

Ele: Acordei de ovo virado hoje, sei lá.

Eu: Ah, claro. E por isso você vai lá e ofende seu patrão?

Ele: Ele tava fazendo um trabalho errado, eu mostrei pra ele como era o jeito certo de fazer, ele continuou fazendo errado, aí chamei ele de burro.

Eu: Simples assim? Não seria melhor lidar com a situação de maneira diferente, como uma conversa, por exemplo? E se ele te demite, como fica?

Ele: Ele não ia me demitir [sorriso]. Sou trabalhador, hoje eu sou um pai de família, quero ver ele me demitir.

Quando cheguei ao MSE, eu substituí uma técnica que iria trabalhar em outro serviço da região. Os adolescentes que essa técnica atendia, dessa forma, seriam divididos primeiramente entre todos os técnicos do serviço e eu ficaria somente com alguns, para que, paulatinamente, me apropriasse do trabalho e depois atendesse um número maior de jovens.

No momento em que sentamos, eu e a gerente do serviço, para decidir quais casos eu iria acompanhar, foi me indicado o caso de André. Ela disse que ele tinha 19 anos. Não entendi, $a$ priori, o porquê dele ainda estar no serviço, já que era maior de idade. Informaram que ele ainda estava cumprindo medida socioeducativa, pois não a havia realizado de maneira satisfatória desde os 16 anos, quando cometera a infração.

O tempo médio de cumprimento de medida varia de três a 12 meses. No entanto, o adolescente pode ficar mais tempo se não desempenha as atividades solicitadas de forma desejada. Quem avalia esse desempenho é o técnico que o acompanha, que através de relatórios periódicos informa ao poder judiciário sobre todo o processo de cumprimento da medida. O juiz responsável pelo caso pode acatar ou não a avaliação do técnico. Habitualmente, diante de um relatório no qual o técnico entendeu que não seria possível a finalização da medida primeiramente imputada ao 
adolescente, o juiz leva em consideração a avaliação e impõe uma nova medida.

No caso de André, esse processo ocorreu muitas vezes, resultando em um total de três anos de permanência no serviço. Depois de falar com a gerente, que forneceu informações mais gerais sobre o caso, perguntei a alguns técnicos o que havia acontecido para que o jovem ficasse por tanto tempo. Minha primeira reação foi imaginar que talvez ele fosse muito perigoso, deixando de cumprir a medida por estar intensamente envolvido com o crime organizado. Quando falei o que pensava, todos riram. "Aquele ali, não faz mal pra ninguém não", desferiu uma técnica que completou, "Ele está longe de participar de qualquer coisa, inclusive do crime organizado". Alguns técnicos até o apelidaram carinhosamente de Wally, por ser parecido fisicamente com o personagem do desenho animado: “Onde está o Wally?".

“Então, por que ele está há tanto tempo aqui?”. Um profissional me respondeu que ele era um menino que "não queria nada com nada". Tinha a característica de comparecer intermitentemente aos atendimentos por poucos meses, e depois, sem oferecer explicações, se ausentava por longos períodos. Apesar desse comportamento, nunca deixava de atender aos telefonemas do serviço. No entanto, quando chamado, não comparecia. Nos atendimentos ele parecia não prestar muita atenção no que estava sendo falado, havia momentos em que se comprometia com o encontro, em outros, não. Sempre que iniciava alguma atividade, como um curso profissionalizante, por exemplo, ele desistia antes mesmo do fim. Para resumir, uma técnica utilizou uma expressão que todos os outros profissionais concordaram prontamente: o André era "perdidão".

Nos meus primeiros encontros com ele, o jovem comparecia irregularmente, oscilando momentos em que se imbuía no diálogo e em outros em que parecia estar alheio. Toda vez que era firmado um novo atendimento semanal, eu escrevia em um cartão a data e o horário exatos para ele comparecer e não se confundir - era costumeiro ele alegar que não havia comparecido pois tinha se confundido com as datas dos encontros -, mesmo assim, não era incomum ele se apresentar com o cartão em mãos, mas em um dia diferente. Mostrava pra ele a incongruência do fato, pois era só olhar no papel. Ele coçava a cabeça, olhava pro cartão tentando entender o ocorrido e me dava razão, dizia que havia se confundido, que jurava que era naquele dia, havia esquecido de conferir a data.

Ele esquecia também frequentemente de diversas atividades propostas e realizadas pelo serviço, e quando se apresentavam as possíveis consequências desses atos, como o descumprimento da medida socioeducativa e a possível internação na fundação CASA, ele parecia não se afetar de maneira significativa, apenas pedia desculpas - e estas pareciam sinceras, não eram realizadas de 
maneira vaga. Prometia que na próxima semana compareceria e, algumas vezes, não era incomum se ausentar novamente. Dessa forma, "perdidão", o adolescente deu início a um processo muito semelhante ao que ele costumava a desempenhar no MSE - como haviam me alertado.

No entanto, após duas semanas sem comparecer ao serviço, o jovem me liga dizendo que gostaria de vir ao MSE para conversar. Estranhei tal atitude, quase sempre desinteressado e agora ele havia tomado a decisão de falar comigo. Chegou, então, até a sala ofegante e com um semblante sério. Sentou na cadeira e olhou para o chão por alguns segundos. Em seguida, disse que sua namorada, Luana, estava grávida. Perguntei o que ele faria a respeito e, ainda olhando para baixo, respondeu que sua vida dali para frente mudaria completamente.

Indaguei quê tipo de mudança seria essa. De imediato, repetiu que tudo se modificaria, mas não soube responder precisamente o quê. No decorrer do contato que vim a ter com o jovem, notouse, realmente, muitas mudanças em vários âmbitos de sua vida.

Sua primeira atitude foi buscar se manter no emprego, na marcenaria onde somente realizava bicos. Ele deu muita ênfase a essa ação inicial. Em todos os atendimentos dali em diante, o tema do trabalho estaria presente. Empenhou-se muito e logo conseguiu se registrar - tinha, pela primeira, vez uma carteira de trabalho.

Pediu-me que o ajudasse a efetivar sua matrícula no supletivo à noite, faltavam apenas seis meses para se formar. Passou a não faltar aos atendimentos, na maioria das vezes era pontual. Quis saber quais eram as atividades complementares do serviço que o ajudariam a ter um melhor relatório sobre seu comportamento. Interessou-se em saber, exatamente, quanto tempo faltava para terminar sua medida - depois de tantos anos lidando com ela.

Nos atendimentos essa mudança se expressou fortemente. A expectativa do filho o lançou a assuntos que antes somente comentava superficialmente. Passou a contar mais extensamente sobre sua família. Como ele cresceu junto de seus dois irmãos e primos em um bairro pobre próximo e sua relação com parentes e amigos.

Falou sobre sua mãe, Tatiana. Era feirante, vendia frutas, e esporadicamente realizava bicos como diarista para complementar a renda. André desde muito pequeno sempre a ajudava na feira, algumas vezes chegou até a trabalhar sem ela, somente com a ajuda da irmã, quando Tatiana estava muita cansada. Segundo o jovem, a mãe era muito cuidadosa com todos.

O único comentário negativo em relação a Tatiana era o fato de que algumas vezes ela se ausentava de casa por algumas horas sem dar explicações, os deixando sozinhos. Um dia, já adolescente, André tomou a decisão de perguntar aonde ela iria e, então, recebeu uma resposta incomum, pelo modo grosseiro como a mãe falou. Ela disse que aquilo não era do interesse dele e 
que não deveria se intrometer nos afazeres dela, já que sua obrigação era somente respeitá-la. Nunca se soube ao certo o que ela fazia nessas ausências. O jovem desconfia que saía de casa para procurar seu esposo, pai dele. Apesar disso, esses sumiços temporários e repentinos nunca foram um problema, pois eram relativamente poucos e de curta duração. No geral, fala dela com carinho, contando que foi Tatiana quem tinha os criado praticamente sozinha. Era a referência familiar.

Já o pai, Augusto, apesar de viver sobre o mesmo teto, sempre se ausentava em muitos sentidos. Quando André falava dele, imediatamente franzia a testa; não gostava do pai. Augusto tinha uma amante e outra família. Passava tempos na casa dela e tempos na do adolescente. Essa situação era velada, todos sabiam, mas não se falava sobre o assunto. Quando criança, André chegou a perguntar algumas vezes ao pai onde ele estava, e este respondia sempre evasivamente. Já adolescente, apesar de não se falar no assunto, durante brigas com o pai, ele mencionava explicitamente a existência dessa outra família para atacá-lo. Augusto nunca negava, ele ficava furioso e não dava continuidade ao assunto. O jovem relata que essa situação somente se manteve pois a mãe gostava muito do esposo, e não queria se separar dele.

Para André, Augusto praticamente não era um pai. Estava sempre distante e quase nunca conversava com os filhos. Quando perguntado se ele contribuía financeiramente para amenizar as despesas de casa ou se trabalhava, o jovem não soube dizer.

Naquele momento, viviam na casa o jovem, a irmã mais nova, a mãe, o pai e dois primos. Estes eram filhos da irmã da mãe de André, que se encontrava morando em outro estado.

No MSE, o adolescente, de preocupado com a notícia da gravidez, passou a ficar muito feliz com a expectativa da chegada de sua filha. Com os meses se aproximando, a cada atendimento ele trazia um nome diferente para ela. Falava que utilizaria o berço da própria prima, e que compraria fraldas e um carrinho de bebê especialmente equipado para as maiores necessidades de um recémnascido - e acabou comprando. Ao final, tinham decidido o nome da filha, seria Andreia, em homenagem ao pai.

No final da gravidez, Luana e André começaram se desentender fortemente. Ele relatava que gostava muito dela, mas que ela era uma pessoa muito "mandona" e "possessiva", difícil de lidar. Duas semanas após o nascimento da filha, eles rompem o relacionamento. No entanto, mantinham sempre contato, pois todos os dias o adolescente, após o trabalho, ia até a casa dela para ficar um pouco com a filha. Era um dos momentos mais felizes do dia.

Em atendimentos, André volta a falar das dificuldades de se relacionar com Luana, mesmo separados. Dizia que ela não cuidava corretamente da filha, que mal tinha dado à luz e já estando frequentando o baile funk, deixando Andreia aos cuidados da ex-sogra. Quase nunca estava em 
casa. E uma das coisas que o incomodavam bastante, era a situação de Luana morar com a filha junto de sua família, enquanto ele, totalmente disposto a ficar com a menina, tinha pouco contato com ela, tendo que se deslocar cotidianamente para vê-la.

Quando Andreia fez um mês de vida, houve uma comemoração na casa da mãe de Luana, Márcia, e André fez questão de arcar com todas as despesas. Estava trabalhando para isso. Apesar dos desentendimentos entre ele e a ex-namorada, a festa transcorria bem, até que uma pequena discussão com Márcia se encaminhou para uma grande briga. Estava garoando e o adolescente abriu um toldo da casa para não molhar Andreia. Márcia caçoou dessa atitude, dizendo que a chuva estava fraca e que ele não sabia cuidar da criança, então fechou o toldo. Para ela, não havia necessidade daquilo. André ficou muito mobilizado com a situação, sentiu-se desrespeitado, desautorizado perante todos - justo ele, o pai, que tinha organizado a festa para a filha.

André, irritado, discutiu com a ex-sogra, pegou a filha nos braços e saiu da casa sem falar com ninguém. Luana, sua mãe e mais alguns convidados foram atrás dele para tentar conversar, e propuseram chamar a polícia caso ele não voltasse. Com medo de que a consequência desse ato resultasse na perda da guarda da filha, como ameaçou Márcia no momento, o adolescente voltou.

O jovem ficou muito abalado com a situação, nunca pensou que poderiam interferir dessa maneira em sua relação com a filha, especialmente quando tinha se dedicado tanto para ser um bom pai e trabalhado para essa comemoração acontecer.

Luana, depois desse dia, passou a evitar as visitas dele. Não se encontrava na casa nos horários costumeiros e não atendia aos telefonemas. André decidiu faltar em um dia inteiro de trabalho para esperar na porta da residência dela, a fim de se encontrar com a filha. Quando Luana se apresentou, disse que ele não poderia ficar ali e que chamaria a polícia caso ele insistisse. Ele disse que a filha era dele também e, por isso, tinha o direito de ficar com ela. Luana aponta que se ele continuasse com aquela atitude entraria na justiça para que ele não pudesse ver a menina. $\mathrm{O}$ jovem duvidou que ela conseguiria cuidar da filha sozinha e ela rebateu dizendo que possui ajuda da mãe, realiza bicos e recebe o Bolsa Família, e, por isso, teria condições financeiras suficientes para criar Andreia.

Diante desse cenário, o jovem se exalta e tenta pular o portão para pegar Andreia. Luana chama os amigos da vizinhança para ajudá-la com a situação. Estes chegam e, além de expulsarem André, o agridem.

Dois dias depois, ele chega ao MSE querendo saber quais seriam as consequências dos seus atos caso ele revidasse as agressões e chamasse seus amigos para ajudá-lo. Queria saber se ele 
poderia se complicar com a justiça já que, em sua concepção, não era réu primário ${ }^{21}$. Querendo entender a situação, perguntei o porquê dessa atitude. Ele sentou e chorou. Disse que não tinha tido uma família "normal", com um pai participativo, e somente queria dar isso à filha. No fundo gostava de Luana, gostaria de ficar com ela, mas se isso não fosse possível, queria estar, pelo menos, presente na vida de Andreia.

Após auxílio do Núcleo de Proteção Jurídica (NPJ), fomos informados de que Luana não poderia concretizar a ameaça que fez sem um motivo muito relevante. O que deixou mais calmo o jovem.

Durante os atendimentos posteriores, André foi se organizando para melhorar sua conduta diante dessa situação. Concentrou-se mais ainda no trabalho. Mostrava orgulhoso os dedos cortados pela serra devido ao serviço na marcenaria. Trabalhava todos os dias, inclusive domingos e feriados. Relatava várias discussões que tinha com o chefe. Muitas vezes discordava dele, o afrontava, mas o patrão não o despedia, pois sabia que André era bom profissional. Ele havia começado a deixar a chave do estabelecimento com o jovem, sinal de que estava fazendo um bom trabalho e era confiável.

Ele e a ex-namorada voltaram a se entender em relação às visitas à filha, acordaram que ele poderia ver a menina sempre que quisesse e Luana estivesse em casa. No entanto, todo o imbróglio ainda ressoava. André, toda semana, dava um dinheiro a Luana para as necessidades da filha. Algumas vezes, ela não queria que ele fizesse isso, alegando que conseguia tomar conta de Andreia sozinha e não precisaria dele. Mesmo assim, o jovem fazia questão de oferecer o dinheiro, dizendo que sua filha teria um pai presente.

Acompanhei André durante todo tempo que estive no MSE - 12 meses. Apesar de meus relatórios favoráveis à extinção de sua medida, meu pedido era negado, pois ele tinha problemas constantes em efetuar sua matrícula escolar, algo que influenciava bastante na decisão judicial. Antes de me desligar do serviço, construí um novo relatório descrevendo detalhadamente todo o percurso do jovem.

Em contato com os profissionais da instituição, tempos depois de minha saída, fui informado que meu último pedido havia sido aceito. Hoje, portanto, após quase quatro anos no MSE, André finalizou seu processo na instituição e não cumpre mais medida socioeducativa.

21 Os meninos depois de cumprirem adequadamente a medida tornam-se réus primários em possíveis outros conflitos com a lei. 


\section{A vontade de ser pai}

Podemos ver aspectos da matrifocalidade tanto na família de André, quanto na de Luana. É a mãe do adolescente quem cuida de toda a casa, e era também quem estava mais próximo dele, trabalhando para sustentá-lo e sendo a referência. A matrilinearidade aparece aqui no fato de dois primos do jovem serem filhos da irmã da mãe. Mesmo com o pai dentro de casa era a mãe quem trabalhava em dois empregos para prover a família, além de cuidar dos afazeres domésticos e criar os filhos e sobrinhos.

Com a família de Luana notamos a mesma característica. Márcia possui tamanha influência familiar que se sente no direito de desautorizar o pai de Andreia, além de caçoar de sua atitude perante todos. Luana não teve dúvidas de que a filha deveria ficar com ela e não com André, tanto que lhe impõe essa decisão e convoca os vizinhos a expulsarem-no.

Woortmann (1987) em seu livro Família das mulheres, descreve como o círculo de amizades do entorno da moradia familiar, composta por parentes e vizinhos, ajuda uma família a criar os filhos; normalmente são famílias de mulheres também. Essa ajuda usualmente seria no contra turno da escola, enquanto a mãe está no trabalho. Aqui vemos que o auxílio da vizinhança se apresentou não nos cuidados com os filhos - já que é a própria Márcia quem ajuda a cuidar -, mas na proteção familiar realizada - com um dado interessante: quem realiza essa proteção são homens, não outras mulheres.

Na família de André, a figura paterna encontra-se parte das vezes dentro de casa, mas não permanece nela sempre. Ele oscila entre duas famílias e isso aparece como um tabu em casa. Ninguém comenta, mas todos sabem. Nesse universo familiar, essa situação impactou o adolescente pela acentuação da ausência do pai, e prioritariamente à mãe por todos saberem do desejo dela e compartilharem essa situação não falada.

Já à ausência paterna, poderia ser delegada importância na medida em que o jovem manifesta seu desejo de ter uma família "normal", ou seja, além da mãe, ter também presente o pai. Se analisarmos melhor, podemos verificar que esse desejo não está relacionado ao pai em si, pois ao falar dele, André demonstra claramente não gostar de Augusto, e na maioria das vezes prefere não comentar sobre o assunto, mesmo quando solicitado. Com isso, quando o jovem cita o desejo de ter uma família "normal", parece não estar se referindo ao pai especificamente, mas ao modelo familiar que imprime sobre ele a importância de se ter uma família constituída com um pai, uma mãe e filhos. 
Esse modelo, em sua concepção, é o considerado normal, ou seja, os outros modelos familiares são, de alguma maneira, os anormais. Essa expectativa de possivelmente viver sob a condição de uma família considerada não nos moldes habituais faz com que ele sofra e chore. Ao mesmo tempo, faz querer oferecer este modelo de família a sua filha.

André relata que gosta de Luana, mas ela não quer ficar com ele. Quando ele consegue ver a filha no portão da casa da ex-namorada, é um momento em que ainda se sente bem, e quando isso passa a não acontecer, invade a residência. No aniversário de Andreia, encontra-se muito feliz e orgulhoso, no entanto quando ele se sente desautorizado de seu posicionamento de pai, toma a atitude repentina de levar filha embora.

Sarti (2007[1996]) comenta a respeito de duas grandes características dos homens na família: o provimento e a honra. Esta segunda está relacionada a mostrar "quem manda" na casa, quem tem a maior autoridade. O provimento no qual o jovem muito se esforçou para desempenhar não surtiu o efeito esperado de autoridade. Sua honra, que está ligada a ser a figura de maior importância da família, foi maculada pela desautorização da ex-sogra. Devido a isso, sua ação foi a de tomar o controle, pegar a filha nos braços e sair daquele local.

A atitude de André, de querer estar com a filha, destoa bastante da de seu pai. Augusto apresentou-se ausente, por viver apenas parcialmente com a família do adolescente. Pouco conhecida, não há a possibilidade dentro da dinâmica familiar de se questionar sobre a outra família dele. Quais são as responsabilidades com a família em questão? Existe mesmo outra família? Qual o posicionamento de cada um em relação a essa situação? Por que não se fala sobre isso? Todas essas questões não respondidas denotam a essa figura paterna um grande desconhecimento sobre sua história de vida e outras características. Por fim, também se trata de uma figura enfraquecida. Não participa das atividades familiares, é alheio aos filhos, à esposa, não acompanha as decisões domésticas, portanto, possui pouca influência familiar.

Uma especificidade de Augusto em relação à função "tradicional” masculina é que não se sabe se ele contribui financeiramente para a casa. Sua figura mostrou-se desconhecida também nesse âmbito, pois quando perguntado ao André, ele disse que não saber. Devido a isso, fui procurar no PIA qual a profissão de Augusto, se ele auxiliava no provimento da casa, e para minha surpresa, seu nome sequer constava nesse documento. Mais uma ausência.

A pedra angular para a mudança de comportamento do jovem, sem dúvida, foi a notícia da gravidez de sua namorada. Sarti (2007 [1996]) destaca que, para o homem adulto, ter uma família sem filhos é como uma árvore sem frutos, ou seja, não há sentido em compor um grupo familiar 
sem ter filhos, é a partir deles que o homem torna-se completo.

Essa concepção do que venha a ser um "homem completo" é extremamente discutível. No entanto, parece estar ainda impregnado no imaginário social que o adolescente compartilha. De um garoto ausente, sem muitos objetivos ou compromissos, "perdidão", André passou a querer ser matriculado na escola, a se interessar em saber de todos os detalhes de sua medida socioeducativa com o intuito de finalizá-la -, participar das atividades, ser pontual, não esquecer dos atendimentos e se imbuir neles como se, somente a partir daquele momento, fizesse sentido falar sobre família e questões pessoais.

A expectativa da chegada de um filho o fez investir em vários aspectos de sua vida. Todavia, o que mais o marcou, foi seu envolvimento com o trabalho. Ele encontrou nesse lugar um porto seguro, uma base para desempenhar outras funções e se estabelecer como pai.

Sempre desatento e não comprometido com atividade alguma, passou a trabalhar todos os dias, fins de semana e feriados com a finalidade de prover sua filha. Mais do que isso, parecia fazer questão de ser pai de sua filha. Imbuiu-se em realizar e financiar integralmente a festa de um mês de vida dela. Em todos os atendimentos falava sobre o seu trabalho, como, por exemplo, a relação com o patrão, e invariavelmente falava da filha assim como do dinheiro que ganhava para arcar com suas despesas, tais como as fraldas e o carrinho de recém-nascido.

Ser pai, em sua visão, implicaria não apenas em prover o sustento de sua filha, mas oferecer cuidados, conviver com ela, além de exemplos - é justamente ao saber que seria pai, que André busca superar a situação de cumprimento de medida socioeducativa. Parecia querer se livrar disso para, enfim, poder se dedicar à nova tarefa de vida: ser pai.

Mesmo se colocando nessa posição, André acaba encontrando uma forte resistência a desempenhar seu papel frente ao posicionamento das mulheres com quem se relaciona. Algumas atitudes do jovem em relação a elas são quase estéreis. Em dois momentos ele se descontrola e pega a filha nos braços em uma tentativa desesperada de exercer sua autoridade e ter sua família, especialmente, no caso, a filha próxima.

No primeiro caso, seu dinheiro, ou seja, seu status de provedor, não surte efeito quando, estando na casa de sua ex-sogra, sob o teto dela, não é permitido que ele exerça sua autoridade, como se a filha já estivesse protegida com a ação da avó. André, primeiramente, estava orgulhoso por pagar toda a festa, puxou o toldo em um sinal de cuidado com a filha, exercendo o provimento econômico e de proteção. Depois se sentiu ultrajado quando esses dois aspectos tradicionais de "homem de família" foram desconsiderados frente a todos da festa. E, então, comete o ato de fugir 
com a menina.

No segundo caso, na invasão de André à casa de Luana, mais uma vez ele utilizou do provimento - material, afetivo e de cuidados - como uma tentativa de se colocar na posição de pai, dizendo à ex-namorada que ele teria condições de sustentá-la. A mãe de Andreia responde que isso não iria acontecer, pois trabalhava, recebia auxílio de sua mãe e do Bolsa Família. Nesse momento, o jovem parece realizar que toda a sua mudança de comportamento depois do conhecimento da existência de sua filha, iniciada por meio do trabalho do qual falava todos os dias, desempenhado com muito esforço de segunda a segunda, cai por terra. Como se suas fichas estivessem acabadas, não havendo mais nada a recorrer para participar da família e exercer outras funções para além do provimento financeiro. Dessa forma, desesperado, ele utiliza a força para agir contra o que estava acontecendo. Para existir dentro daquele grupo que havia dado sentido para diversos aspectos de sua vida, ele invade a casa e sai com a Andreia. Entretanto, foi expulso, tiram-lhe sua filha, e ele chora por sua família.

Em outra ocasião, mais uma vez, Luana deixa claro que não precisa de ajuda para criar a menina, e, no entanto, o jovem faz questão de deixar dinheiro com ela, como se, reiteradamente, essa fosse sua obrigação da qual não estava se eximindo e sentia-se satisfeito por realizá-la, já que vinha sendo paulatinamente impedido de exercer outras funções.

André tenta desempenhar a função tradicional de homem como provedor de alimento, teto e respeito, assim como foi cunhado por Sarti (2007 [1996]), contudo essa ação não encontra espaço dentro desse grupo familiar. Em relação ao respeito, ele é desautorizado em dois momentos, por Luana e Márcia, que apontam que o provimento de alimento e teto não é exclusividade dele.

Luana, em determinado momento, deixa claro que não precisa da ajuda de André, pois recebe auxílio da mãe - evidenciando o aspecto matrilinear da família - realiza bicos - apontando para o fato de Luana, assim como André, também trabalhar - além de ser beneficiária do Bolsa Família.

Em relação a esse programa de transferência de renda, devemos nos ater sobre a sua importância. Em todos os casos aqui relatados mais extensamente, ele aparece como uma forma de contribuição para a autonomia financeira da mulher. Não vamos nos alongar tanto sobre suas características, pois não é o foco do trabalho. No entanto, devemos pontuar o seu impacto no orçamento dessas mulheres e na dinâmica de suas famílias.

Para caracterizar rapidamente ${ }^{22}$, Bolsa Família é um programa federal de transferência direta de renda, condicionado, destinado a famílias em situação de pobreza ou extrema pobreza, com o

22 Para maiores informações acessar: www.mds.gov.br/bolsafamilia. 
objetivo de promover o alívio imediato da situação de pobreza e possibilitar o desenvolvimento de capacidades para sua superação. O saque desse dinheiro está vinculado hegemonicamente ao nome da mulher representante da família.

Nos casos das famílias aqui descritas, Fabiana recebia o benefício. Elis tomou a decisão de sair de casa e viver com Dilan, apoiada em sua situação laboral e também no auxílio do Bolsa Família. Luana expressa literalmente sua condição de escolher viver sem André, dentre outros fatores devido ao programa de transferência de renda. Podemos verificar que, de certa forma, esse programa possibilitou uma autonomia para essas mulheres, um determinado início de emancipação, proporcionando, principalmente a Elis e Luana, terem a opção de escolher viver com ou sem o pai de seus filhos, ou ainda, sair do grupo familiar em que estavam, optando por outro que lhes convieram.

Rego \& Pinzani (2013) discorrem sobre como esse benefício impactou a renda de famílias pobres a ponto de afastá-las de uma ditadura da pobreza. Oferecendo, principalmente às mulheres, a possibilidade de fazer escolhas que até então inexistiam - ainda que não retirando dessas pessoas a condição de serem pobres. Verifica-se que

As mulheres a partir do recebimento da renda monetária, se apoderam de alguma forma da capacidade humana, como a de escolher certas opções, inclusive, como já se falou anteriormente, as de ordem moral. (Rego \& Pinzani, 2013, p.196)

Sem desqualificar o programa no combate à pobreza e o avanço na qualidade de vida de seus beneficiários, há de se perguntar sobre os impactos nas relações e no convívio familiar. Os autores colocam que, por exemplo, o benefício vem possibilitando que mulheres superem situações de violência doméstica, ao separarem-se de companheiros que as agridem, como veremos também mais adiante. Mas pouco se sabe o quanto o programa vem impactando na responsabilização de homens pelos cuidados familiares e como viria intensificando ou não as possibilidades de convivência familiar. Ora, paradoxalmente, o programa que promove a autonomia de mulheres historicamente subordinadas a homens - também, no caso aqui discutido, contribui para o afastamento de André como figura paterna

Por fim, devemos aqui separar em dois momentos a participação de André. Em todos os 
casos apresentados, os adolescentes com quem estive em contato participavam familiarmente na condição de filhos. Nesta análise, André aparece como filho em um momento e pai em outro. Como filho, ele exerceu um posicionamento muito parecido com a dos outros meninos ${ }^{23}$ no que diz respeito ao provimento da casa. Exercia um preponderante papel dentro de casa, auxiliando a mãe no trabalho na feira enquanto seu pai, Augusto, estava em segundo plano. Apesar do provimento, o jovem não tinha autoridade familiar de um pai de família. Um exemplo disso ocorreu quando ele perguntou à mãe o que ela fazia quando saía de casa, e esta respondeu que não era para ele se "intrometer" no que ela fazia, ele tinha somente que respeitar.

O jovem, já como pai, exige a autoridade que compete a esse lugar na maneira tradicional familiar. Coloca-se na posição de provedor e exige respeito e autoridade sobre a filha. Ele provê na medida do possível, mas, em seu caso, a autoridade lhe é retirada constantemente por Luana e Márcia, principalmente por sua influência financeira ser desconsiderada, bem como o oferecimento de cuidados. Alguns fatores compuseram essa situação para a família apresentada. Há uma condição relacional - mãe e filha se comprometerem a cuidar da criança -, laboral - Luana trabalha - e econômica - o salário e o auxílio do Bolsa Família - de ambas. Seria isso um indício de início de emancipação feminina?

A relação de André com Luana mostrou-se singular. Mesmo separado, ele ensaiou um controle sobre ela ao reclamar que ela está indo ao baile funk e permanecendo pouco em casa. No entanto, essa postura está relacionada ao fato da ex-namorada não cuidar da filha de maneira satisfatória, segundo sua avaliação. André afirma que gosta de Luana, mas seus comentários em relação a ela são sempre relacionados à filha também, ou seja, à família composta pelos três.

Como pai, portanto, ele tenta exercer uma função tradicional, mas acaba esbarrando no posicionamento de Luana e Márcia.

23 Poderíamos excetuar Gustavo, entretanto, quando sua mãe sai de casa, sua reação é ir procurar um emprego. 


\section{Capítulo V}

\section{Grupo de Família}

\section{1. lugares de homem e de mulher}

O Grupo de Família é uma das atividades regulares realizadas pelo MSE. Ela ocorre mensalmente, sempre no último sábado. Esta é a única atividade destinada exclusivamente aos familiares, ou seja, nela os adolescentes atendidos não podem comparecer. Essa característica tem a finalidade de deixá-los mais à vontade para se expressarem.

O intuito do grupo, além de apresentar e discutir temas relevantes ao cotidiano das famílias atendidas, é o de promover o maior contato entre os técnicos e os familiares do adolescente. Normalmente, seus temas de discussão surgem dos atendimentos e nos próprios grupos de família anteriores. São demandas que são transformadas em pautas de debate. Essa atividade não é obrigatória, participam os familiares que voluntariamente se interessam pelo espaço apresentado.

Localizada a demanda, todos os técnicos se reúnem para discutir e preparar o material que será utilizado no dia.

O grupo tem a duração de três horas, das 9:00hr às 12:00hrs, e é composto por cinco partes. Primeiramente, há a recepção. Nela recebemos as pessoas que nunca participaram da atividade e explicamos sua finalidade. A segunda parte é o café da manhã. Todos, inclusive os técnicos, se reúnem em torno de uma mesa de café da manhã para comerem e conversarem livremente. Após essas duas partes o grupo é chamado a uma grande sala onde ocorre a realização da leitura de um pequeno trecho de determinado livro, ou um conto, com o intuito de estimular o interesse pela literatura e pela ação de ler de modo geral. Na quarta parte é realizada uma dinâmica de grupo, como, por exemplo, brincadeiras de roda, a fim de descontrair e deixar os participantes mais ambientados ao local. Por fim, é realizada a discussão do tema preparado para o sábado, que concentra a maior parte do tempo do encontro.

Como ex-técnico do serviço, eu havia proposto aos profissionais realizar um grupo de família no qual pudéssemos discutir sobre o meu tema de mestrado, visto que seria condizente com questões do cotidiano dessas famílias - lembrando que o presente tema surgiu justamente de minha experiência com as famílias desse serviço. 
Todos gostaram muito da ideia e, imediatamente, aprovaram a realização do grupo. Disseram que o assunto estava mais vivo do que nunca e em seguida relataram dois casos. Um envolvendo uma família em que a mãe de dois meninos - um deles atendido pelo MSE - havia se separado do marido, pois ele não trabalhava com carteira assinada e não "andava na linha" - o que significava que ele frequentava bares nos fins de semana sem ela - desde então ela estava vivendo muito melhor que antes e sem grandes problemas. Por outro lado, também relataram o caso de uma mulher que praticamente não saía de casa sem a permissão do marido e que este, vez por outra, a agredia por discordar da forma como ela se posicionava diante dos filhos. Uma das técnicas disse: "esse empoderamento da mulher é extremamente visivel, uma forte tendência, no entanto grande parte das mulheres ainda sofre com os mandos e desmandos dos homens".

Logo quiseram saber como seria realizado o grupo. Respondi que, apesar de querer utilizá-lo como um dos dados para a minha pesquisa, não gostaria que a pergunta disparadora da discussão fosse idêntica a do objetivo da dissertação. Gostaria que fosse algo mais "solto", descontraído. Propus dessa forma, pois queria que as pessoas pudessem falar o mais livremente possível sobre o assunto, sem grandes amarras, e que contassem sobre fatos de seu cotidiano, não se prendendo a dar respostas prontas.

A ideia do grupo seria algo simples. Uma grande roda de discussão com os familiares, utilizando algumas perguntas norteadoras, na qual eu mediaria. Essa primeira proposta não seria um bom caminho, segundo os técnicos. Foi-me explicado que, como a grande maioria dos participantes eram sempre mulheres, uma roda de discussão em que fosse debatido o lugar do homem e da mulher na família geraria, segundo eles, uma série de discursos delas contrários ao posicionamento familiar ausente dos homens e relatos do quanto elas trabalhavam e se esforçavam para conseguirem criar os filhos praticamente sozinhas. Coloquei que, se assim fosse, eu gostaria de ouvi-las. Contudo, alertaram-me que as mulheres ficariam muito mobilizadas pelo assunto resultando em uma roda de conversa difícil de manejar pelo grande volume de discussões paralelas.

Dessa forma, propus então que dividíssemos os participantes em grupos menores, e que dois técnicos seriam responsáveis por cada grupo. Expliquei o objetivo da pesquisa e formulei algumas perguntas que serviriam apenas para disparar a discussão. O principal seria propor uma conversa baseada nelas ${ }^{24}$.

No dia do grupo vieram somente oito pessoas: sete mães e um pai. Expliquei primeiramente como seria a atividade e, em seguida, dividimos os participantes em dois grupos de quatro integrantes. Eu fiquei em um deles junto de uma técnica, e este era composto por quatro mães. Dois

24 Em anexo, as perguntas disparadoras. 
técnicos ficaram no outro, com três mães e um pai.

Após a atividade, fizemos uma reunião, eu e os técnicos, para saber como foi a conversa com o outro grupo. Discorrerei sobre o grupo de que participei e, à medida que surgirem pontos relevantes à nossa discussão, trarei as informações do outro grupo. O que pudemos notar, já de antemão, foi uma grande semelhança nos conteúdos dos dois grupos.

A primeira pergunta era a respeito da composição familiar de cada um. Três das quatro famílias eram compostas por pai, mãe e filhos. Somente uma era configurada com a presença da mãe, a avó (por parte de mãe) e o filho. Foi perguntada a opinião delas sobre o porquê de a maioria dos integrantes de um grupo de famílias serem mulheres e não homens. Nesse momento, entendi o motivo de se dividir o grupo. Todas começaram a falar, quase ao mesmo tempo, sobre o quão displicentes e irresponsáveis eram os maridos por não participar das atividades relacionadas ao filho.

"Homem é assim mesmo, falou em acordar cedo no sábado, eles não vêm. A desculpa é porque trabalha a semana inteira e está cansado. Mas eu também trabalho e estou aqui!”, “Eu acho uma irresponsabilidade, ele devia estar aqui", "É compromisso de família, ai só vem mulher mesmo", "Disse que no próximo viria, mas falou a mesma coisa mês passado. É só a mulher mesmo para ter esse tipo compromisso".

Além da indignação que essas mulheres têm com o comportamento de seus companheiros em relação aos filhos - pela maneira vívida como realizavam os comentários -, nessas falas aparece nitidamente que os compromissos familiares são de responsabilidade das mulheres, enquanto os homens se remetem a artifícios, desculpas para não comparecerem, ou seja, não se responsabilizam por isso.

Em uma das respostas é demarcado o espaço do trabalho como sendo masculino, assim como suas consequências, como o cansaço, por exemplo. Isto está tão arraigado como algo típico do homem que, além de ser utilizado como grande motivo para não participar das atividades do filho, não leva em consideração que a mulher também trabalha, e com isso também pode estar cansada. Entretanto, mesmo assim, é ela quem acaba comparecendo. Outras respostas são dadas nesse sentido, como a de que compromisso familiar compete a elas.

Um fato curioso que ocorreu no outro grupo foi em relação ao único homem presente. Ele chegou ao MSE acompanhado da mulher. Esta, junto dele, tomou o café da manhã, entretanto recebeu um telefonema e teve que sair às pressas; ele permaneceu. No grupo ele manifestou seu incômodo com a atitude da esposa. Disse que se tiver um compromisso, ele não desmarca assim, à 
toa. Ela recebera um telefonema do outro filho - o que não cumpre medida socioeducativa dizendo que precisaria dela para ir até a escola participar de uma festa junina. O pai disse que nunca teria feito algo como aquilo. Abandonar um compromisso sério, que era a participação em um evento que envolvia a situação legal de um filho, para levar o outro a uma "festinha de escola".

Nota-se como ocorre essa separação feita pelo pai. Sem entrar no mérito do que seria mais ou menos importante, ele liga o fato de sua participação no grupo a algo sério, que "envolve a situação legal do filho", remetendo ao aspecto jurídico, algo que seria de grande importância, e atrela sua decisão de ficar a esse fato. Em seguida, condena a ação da mulher, dizendo que nunca realizaria tal atitude, a de levar o garoto a uma festinha da escola. Ou seja, participar de uma festa junina do filho seria algo menor, que ele não faria - lembrando que a participação no grupo de família do MSE é facultativa -, não desmarcaria por esse motivo, "à toa”. Mesmo ambos os eventos sendo relativos aos filhos, estabelece-se uma divisão daquilo que seria o compromisso do homem o aspecto legal, jurídico do filho, mais importante - e o da mulher - a festinha da escola, um compromisso menor.

Voltando ao grupo do qual participei diretamente, discutimos sobre as atribuições da mulher e do homem dentro e fora de casa - nesse momento já não havia perguntas de fato, somente a conversa inspirada nelas. Elas falaram que antigamente o dever da mulher era o de servir ao marido e cuidar das coisas de casa. Enquanto os homens saíam para trabalhar cedo e voltavam somente à noite, as mulheres ficavam o dia inteiro dentro de casa. Uma das mulheres do grupo falou que "havia um massacre na cabeça das mulheres, principalmente quando já eram mães, de que elas deveriam ficar em casa trabalhando nas coisas de casa, e isso [a atitude de somente trabalhar em casa] já era mais do que suficiente [para realizarem, como obrigação delas]”. Ela continuou, dizendo que seu pai obrigava sua mãe a permanecer dentro de casa na maioria do tempo. Quando ainda morava no nordeste do Brasil, esta fazia doces para vender, e mesmo realizando esse trabalho que rendia financeiramente mais que o dele, ela era desmerecida, diminuída e desautorizada por ele perante a família. Quando, por qualquer motivo, ele decidia que ela deveria parar de vender os doces, assim acontecia, mesmo que fosse prejudicial a todos.

Aqui, além de ocorrer uma atitude machista e misógina, está presente um modelo familiar no qual o homem possui a maior autoridade dentro da família, independentemente do provimento em si. A mãe ganhava mais que ele, trabalhava em serviços domésticos, cozinhava, fazia doce para vender fora de casa e cuidava dos filhos. Mesmo assim, era subordinada a ele, como se o lugar dela fosse fixo, enclausurada dentro da residência. Independente de qualquer coisa, de qualquer atitude, estava destinada, seja qual fosse a conjuntura, a ficar dentro de casa e se submeter ao marido. 
Apesar da "criação" dessas mulheres ter esse modelo, ou seja, foram ensinadas a servir ao marido e a ter como exemplo dentro de casa a própria mãe, hoje, segundo elas, a situação havia mudado. Era bem diferente e melhor. Agora trabalhavam fora, tinham seu próprio dinheiro e o homem tinha que ajudar nos serviços domésticos também. Além disso, todas foram unânimes e incisivas ao falar que eram elas quem "mandavam" em casa.

Indaguei, então, sobre essa condição. Das três que tinham maridos, todas disseram que dividiam os afazeres domésticos. Destas, uma relatou que metade das coisas quem fazia era ela, e a outra era ele, e em seguida brincou" ${ }^{25}$ : "a maior felicidade do meu dia é quando chego em casa depois do trabalho e vejo ele varrendo o quintal". As outras duas falaram que partilhavam as tarefas, todavia, os maridos eram preguiçosos, ajudavam somente de vez em quando e escapavam de algumas obrigações. Perguntei, então, o que elas faziam quando eles se eximiam dessas obrigações. Ambas disseram que elas acabavam fazendo o serviço, afinal de contas, "vou deixar a casa suja?", "Se eu não fizer, quem irá fazer?".

Excetuando o primeiro caso, em que as divisões das tarefas parecem estar em situação de igualdade, as outras as dividem parcialmente, inclusive no que diz respeito à criação dos filhos. Em última instância, são elas quem têm a obrigação de realizá-las. O verbo utilizado por essas duas mulheres do grupo ao se referirem às obrigações domésticas do marido foi: ajudar. Ou seja, parece que eles não estão responsabilizados igualmente nesta atividade, e se eles não fizerem, são elas que acabam fazendo, evidenciando que, ainda assim, quem tem a obrigação de fato de cumprir com as tarefas domésticas são elas.

Esse dado se repetiu com todas as três mulheres do outro grupo. O homem afirmou que também ajuda dentro de casa, mas que, nesse espaço, a mulher trabalha apenas um pouco mais que ele.

Seis das sete mulheres trabalham com carteira assinada. Aqui é evidenciado que a maioria das mulheres faz a jornada tripla, serviço dentro e fora de casa, além de criar os filhos. No entanto, essa jornada, no que diz respeito ao trabalho doméstico e a criação dos filhos, parece ser apenas amainada com a ajuda dos companheiros. Outro fator importante está na legitimação dessa posição masculina e feminina pelos homens. Apesar de não partilhar de maneira igual as tarefas, eles aceitam teoricamente a condição de terem também que criar os filhos e desempenhar as urgências domésticas. Esse "novo" posicionamento do homem dentro de casa é, de alguma maneira, aceito e legitimado por eles; um exemplo disso, é o não questionamento deles do porquê também terem a obrigação de executar essas tarefas - tanto que recorrem a artifícios e desculpas momentâneas para

25 Pelo menos eu achei que estivesse brincando. 
não realizá-las.

A única mulher que não tinha carteira assinada, também não trabalhava. Ela era considerada pelos integrantes do grupo como sendo de "classe média", ou seja, talvez não necessitasse trabalhar.

Conversamos sobre como elas gastavam o dinheiro que recebiam no trabalho. As quatro disseram que além das despesas usuais de casa, elas também compravam coisas para elas, como cremes de cabelo, maquiagem, ingressos para shows de pagode, entre outros. Citaram também o auxílio do Bolsa Família na composição desses ganhos.

Aqui vemos como o trabalho proporcionou a elas uma condição de certa autonomia, resultando também em um cuidado com elas mesmas. O Bolsa Família mais uma vez aparece nesse cenário. Em relação ao programa de transferência de renda, Rego \& Pinzani (2013) comentam:

Algumas entrevistadas "confessaram”, às vezes com tão visivel quanto injustificado sentimento de culpa, que de vez em quando usam o dinheiro da bolsa para comprar um batom ou um creme para o cabelo. Essas atitudes configuram um tipo de morality of spending que age fortemente sobre suas subjetividades (Rego \& Pinzani, 2013, p. 198, grifo dos autores)

No caso, as mulheres do grupo de família não pareciam se sentir culpadas por seus gastos.

Perguntei, caso os cônjuges tivessem uma renda suficiente para arcar com todas as despesas de casa, se elas parariam de trabalhar. Todas, prontamente, reagiram de maneira efusiva, algumas até dando risadas. "Jamais! Nunca pararia de trabalhar”, "Não! Por coisa nenhuma desse mundo. Ter meu dinheiro foi uma benção, uma liberdade mesmo”, "Imagina, agora que eu comecei a ter as minhas coisas, eu vou dar um passo pra trás?”. Como presente nas respostas, trabalhar não tem o sentido somente de pagar as contas, mas de uma atitude que visa certa liberdade pessoal, uma conquista que elas não querem perder.

A situação do trabalho formal e de renda reposicionou essas mulheres no âmbito familiar, quase não é mais uma opção para elas não trabalharem fora de casa. Isso impacta as dinâmicas familiares, pois faz parte do desejo da mulher, como uma conquista emancipatória, ter seu dinheiro - não o "dinheirinho" - e seu emprego. Devido a essa decisão, o modelo familiar fixo pautado na mãe dentro de casa e no pai na rua, mais do que colocado em questão, é excluído como 
possibilidade, resultando em uma forma de relação familiar diferente da tradicional. É de se imaginar que reposiciona homens também no âmbito familiar, já que não são mais os principais responsáveis em prover o sustento de suas famílias. Sem essa tarefa, que novas tarefas passariam a ter? Aliás, passariam a ter?

Aqui começamos a perceber um aspecto de como estão embasados os posicionamentos de homens e mulheres nessas famílias. A vontade das mulheres de terem alguma independência por meio do trabalho pesa para que essas famílias possuam as características que têm. Não ouvimos os seus companheiros para termos uma maior noção de como eles enxergam essa conjuntura familiar. O único homem que compareceu no grupo falou um pouco sobre isso.

"Mudaram muito as coisas. Em relação ao trabalho eu deixo... quer dizer, eu apoio o fato da minha esposa trabalhar, é assim que as coisas estão hoje em dia, muitos gastos, a mulher tem que trabalhar mesmo, e a gente aceitar. Mas é claro, eu não fui criado assim, pra mim é diferente ver tudo isso, quer dizer, pra todo homem, né? Às vezes eu fico meio perdido mesmo, sem saber direito o que fazer, homem trabalhava e mulher ficava em casa cuidando dos filhos. Agora mudou, mas a gente se arranja".

Nessa fala vemos como a situação impacta o homem. Ele começou a dizer a segunda frase como se ele estivesse permitindo que a esposa trabalhasse, e logo corrigiu dizendo que apoiava a atitude dela. Frisa que a situação do trabalho da mulher mudou e os homens, inclusive ele, têm que se adaptar. Conta que não foi criado para estar nessa posição, ver a mulher trabalhar fora. E, por fim, diz estar perdido com a nova situação, pois antes "homem trabalhava e mulher ficava em casa cuidando dos filhos".

Em uma avaliação informal dos técnicos que acompanharam esse grupo foi dito que ele parecia estar realmente perdido em meio às três mulheres que se colocavam e não paravam de falar sobre suas situações e conquistas, seja no mercado de trabalho ou, seja quanto à autoridade no ambiente familiar.

Mas não estariam todos perdidos nessa nova configuração? Se homens e mulheres foram criados para atender a outras expectativas de papeis, funções e tarefas, como vivem novas possibilidades de mudança, de deslocamento desses lugares? Luana, a jovem mãe da filha de André parece trazer indícios de que essa nova configuração - em que homens podem oferecer algo para além do dinheiro - é uma novidade quem vem sendo vivida com muitas dificuldades. 


\section{Cenas de outros grupos: O preço da "emancipação" ou do inchaço das tarefas femininas}

Apresentarei e problematizarei algumas cenas ocorridas em outros grupos de família.

Uma mãe, Maria, ao final do grupo de família, veio me procurar para perguntar como era o procedimento para tirar novos documentos, pois ela havia perdido sua carteira. Quando comecei a explicar, ela mudou de assunto e começou a falar de sua relação com os vizinhos. Disse que sabia que alguns deles a criticavam por ter um filho que estava em situação de conflito com a lei. Isso a magoava bastante. No entanto, no caminhar da conversa, viu-se que o que mais a incomodava não era tanto a opinião dos vizinhos, mas o sentimento de culpa que carregava por seu filho ter cometido um roubo.

De alguma forma ela se culpava pela atitude do garoto. Dizia que havia criado seus cinco filhos sozinha, e somente o último tinha se enveredado pelo caminho do crime. Em sua concepção, com os quatro primeiros ela tinha sido mais rígida e próxima. Com o passar dos anos, os filhos mais velhos tornaram-se adolescentes e ela passou a delegar algumas funções a eles no que concerne ao cuidado com o caçula. Depois de anos se preocupando de forma intensa, Maria conta que tinha decidido relaxar um pouco, deixou de dormir às duas horas da manhã - quando finalizava os afazeres domésticos - e passou a ir para cama mais cedo quando instruía os filhos mais velhos a terminarem com os serviços da casa e ajudassem nos cuidados dos filhos mais novos.

Para ela foi essa atitude que fez com que o caçula fosse para o mundo do crime. Maria deixou de estar próxima, como era com os outros para poder descansar mais. Em seguida disse que se tivesse alguém, talvez um pai, mas não necessariamente ele, que pelo menos a ajudasse a cuidar dos seus filhos, as coisas poderiam ser diferentes.

Nessa conversa podemos perceber como a mãe transita de uma preocupação, a priori, destinada aos comentários dos vizinhos, para uma inquietação consigo mesma. Ela se coloca em uma posição de total responsabilização em relação às atitudes do filho, em um pano de fundo, onde o seu principal dever seria o de educar seus filhos, e caso esse objetivo não fosse alcançado de forma satisfatória, ela seria a culpada.

Salem (1980) aponta em seu estudo com famílias pobres que a principal obrigação da 
mulher no âmbito privado seria a educação dos filhos. Quando questiona o porquê do homem não compartilhar essa função, recebe respostas de que simplesmente essa seria a função da mulher em casa, não do homem, e que não seria bom para os filhos receberem ordens de duas pessoas. Além disso, esse posicionamento da figura paterna sendo desresponsabilizada pelos cuidados com os filhos era justificado, na maioria das vezes, pelo fato dele estar trabalhando fora de casa, e por conta disso não participaria dessa função.

Esse ideário de que a mulher é a responsável por educar os filhos parece ser muito presente nesse relato - e em outros, como veremos a seguir. O pai não estava presente, mas mesmo sendo ajudada pelos filhos mais velhos, ela imediatamente se responsabiliza pelo garoto ter cometido a infração, remetendo-se à falta de um pai, ou melhor, à ausência de alguém, de outra pessoa, como um fator importante.

Notemos que, mesmo sendo auxiliada pelos filhos - outras pessoas, como ela desejava -, persiste ainda a sensação de dever não cumprido, de ter falhado. Parece predominar a concepção de que uma família composta somente pela mãe e os filhos seria fadada ao insucesso, ou a causa do comportamento condenável do filho. Mesmo perante ao fato de ter criado os quatro filhos anteriores de maneira desejável - segundo ela - o ato infracional do quinto fez ela se culpar e se remeter à ausência da figura paterna como fator importante para o comportamento do filho.

Outra questão a qual ela se remete, é em relação a ter descansado mais após o quinto filho, especificamente, de ir dormir duas horas mais cedo do que o habitual em prol de si mesma. Devido a isso, culpa-se por não ter se dedicado de maneira ideal ao filho, como se esse fato pudesse ter causado o ato infracional dele. Temos, novamente, o ideal de que ela é a total responsável pelos atos do filho. Excluem-se, aqui, outros fatores que compõem o todo que levou esse garoto a cometer a infração.

Em conversa com outra mãe, Ana, imigrante nordestina, ela também se culpa pelo ato infracional do filho. Conta que, quando o menino ainda era bem pequeno, decidiu expulsar o marido de casa porque ele começou a beber demais e a ficar violento com ela e o filho, agredindo-os. $\mathrm{Na}$ época, trabalhava e recebia a ajuda das vizinhas nos cuidados com o filho; dessa forma, se viu em condições de mandar o marido embora de casa. Desde então, não se envolvera seriamente com nenhum companheiro.

Ana, mulher sempre muito altiva, falante e determinada, conta com lágrimas nos olhos, em 
tom de confissão, que não entende a razão do filho ter se envolvido com o tráfico. Sempre acreditou que o que estava fazendo era o correto, não havendo motivos para ter educado errado, já que cuidava do filho e não deixava faltar nada em casa. Em seguida chora.

Desabafa em voz baixa que talvez tivesse errado em achar que poderia dar conta de cuidar do filho sem um pai, sem um companheiro, que acreditou em uma postura de "mulher resolvida e independente", mas que tal atitude, no entanto, tinha dado errado: seu filho estava no mundo do crime.

Conta que em alguns momentos escutava a voz de sua mãe, mulher nordestina, muito simples e "tradicional", questionando o porquê de ela ter expulsado o marido de casa; que com o tempo a situação com ele melhoraria - o problema do ex-marido (ser violento) era passageiro; "ruim com ele, mas pior sem ele". Ana conta que nos "momentos de fraqueza", ela realmente se questiona se fez a coisa certa, se não era melhor somente ter seguido os conselhos da mãe, ter permanecido com o ex-companheiro mesmo com seus defeitos.

Em nossa conversa, instaura-se um breve silêncio, ela me olha, seca as lágrimas, tenta se recompor e rapidamente diz que esses eram "só" momentos de fraqueza mesmo, que sabe que tinha feito a coisa certa, e que eu não deveria me preocupar não, ela sabia "se virar". E com um sorriso forçado no rosto se encaminhou até o portão de saída.

Nesse relato estão presentes alguns fatores, dentre eles a compreensão extremamente equivocada de que o ato infracional do filho é resultado necessariamente de uma criação inadequada da mãe. Esse aspecto possui várias facetas que infelizmente não desenvolveremos aqui por ultrapassar o mote do trabalho. Na verdade, estamos trabalhando a concepção de que o que leva um garoto a cometer uma ação dessas é resultado de muitos fatores que permeiam seu comportamento, e muitos deles não possuem ligação alguma com sua mãe ou com suas relações familiares.

Além da culpabilização da mãe pelo ato do filho, uma característica importante que devemos notar é um modelo de família que ainda aparece como normativo e causa sofrimento. Ana tem uma atitude em relação à sua família muito diferente de sua mãe. Ela decide não ter o seu marido em casa, em prol de seu bem estar, optando por criar seu filho sem um pai. No entanto, esse modelo de família foge do nuclear, pai, mãe e filhos, àquele em que Ana foi criada. Quando acontece algo que considera ruim na criação de seu filho, ela se culpa por ter escolhido outro modelo - mãe e filhos - e logo pensa que pela ausência da figura do pai dentro de casa que o filho entrou para o tráfico.

Não são questionados outros fatores que poderiam levar a essa atitude do garoto. Mesmo 
Ana sendo uma mulher que conseguiu certa autonomia na constituição de sua família - mãe e filho -, o ideário de que a família "boa" e normal é a nuclear aparece com grande força, a falta dela, na visão de Ana, é o motivo do comportamento errado do filho.

Situação semelhante a de Antônia.

Antônia é uma mulher alta, negra, de riso fácil e sempre muito falante. Trabalhava como diarista e vivia somente com os dois filhos. Ela era uma das mães que mais comparecia ao grupo de família. Certa vez, muito contente, contou para mim de como ela dava "nó em pingo d'água" para desempenhar sua jornada tripla. Aparentava ter cerca de 40 anos, no entanto, tinha 28.

Saía da zona sul todos os dias, e ia em direção à zona oeste e ao centro de São Paulo. Levantava às cinco da manhã, acordava os filhos e os levava para a escola. Em seguida se dirigia até a estação Luz do metrô para o primeiro trabalho do dia. O serviço era em uma casa grande. Normalmente durava um dia inteiro para finalizar; no entanto, ela conseguia fazer somente no período da manhã para dar tempo de ir até à zona oeste, trabalhar em outra casa. "Tem que fazer dinheiro, não é João, se não, quem vai dar o leite para as crianças?”, falou pra mim seguido de uma risada alta. Depois de duas horas no ônibus de volta, chegava em casa mais ou menos às oito da noite e, depois de cozinhar, limpar e arrumar a casa de terceiros, fazia o mesmo na própria residência, enquanto ajudava os filhos com a lição da escola.

Apesar das inúmeras tarefas desempenhadas no dia e de seu semblante cansado, Antônia conta sobre seu cotidiano sempre de forma alegre. Dizia que era uma mulher "de fibra", nordestina, que consegue honrar com todos os seus compromissos sem esmorecer. "Comigo é assim João, não tem "chororô" não, eu aguento o tranco do dia a dia com o sorriso no rosto e alegria pra dar e vender!", em seguida solta outra risada.

Diante de tanta alegria em meio a muitas demandas e dificuldades cotidianas, perguntei-lhe se havia algo em seu dia a dia que a deixava triste. Ela mudou sua expressão, ficando mais consternada. Disse que ficar longe dos filhos durante longo período do dia era difícil, já que trabalhava muito e restava pouco tempo para ficar com eles, cuidar, criá-los da melhor maneira. Em seguida falou que se tivesse um marido, sua situação melhoraria consideravelmente. Concordei e comentei que com alguém ao seu lado a renda da casa poderia aumentar, talvez ela não teria que trabalhar tanto, dividiria o cuidado com os filhos. Antônia, então, interrompeu-me e disse que não estava falando sobre isso. $\mathrm{O}$ que mais ela sentia falta era de alguém para compartilhar seus 
momentos, suas questões, dúvidas e felicidades. Há muito se dedicava quase que exclusivamente aos filhos e isso não era um fardo. O que a incomodava era somente fazer isso de sua vida, e não ter alguém ao seu lado para dividir suas experiências.

A vontade de um companheiro, além de possibilidade de se compartilhar a vida, fala da vontade de uma família ideal, normativa. Família esta, que seria a salvação para grande parte dos problemas vividos por essas pessoas, cujas famílias se mostram distantes desse modelo. Marta nos ajuda a pensar sobre isso.

Marta se aproxima para dizer que, dessa vez, seu filho, Diego, não trará mais problemas a ela. Finalmente ele tinha encontrado um "rumo na vida". Diego acabara de anunciar seu namoro com uma menina que Marta considerava "boa pra casar”. Indaguei sobre essa sua certeza e ela me explicou que os homens "são assim": precisam ter uma família, esposa e filhos, para aprenderem a ter responsabilidades. Em seguida relatou o exemplo de seu pai. Ele era conhecido em sua comunidade por ser "mulherengo”. No entanto, depois que casou com sua mãe, passou a trabalhar e “andar na linha”.

A resposta de Marta traz a concepção de que uma constituição familiar específica - ter esposa e filhos - influenciaria o comportamento não somente de Diego, mas como os dos demais homens no sentido de passar a terem responsabilidades. Mais uma vez, esse modelo familiar é classificado como o desejado, aquele que modifica positivamente as ações dos homens. Por fim, Marta utiliza como exemplo sua própria família.

Nos casos apresentados, podemos verificar que apesar das mulheres se mostrarem ativas frente às suas famílias, compostas, em sua maioria, sem um pai, o modelo de grupo familiar baseado na família nuclear ainda representa o modelo ideal, normal, certo e desejado. De diversas formas a busca por essa constituição familiar cria expectativas, muitas vezes idealizadas, o que causa posteriores sofrimentos quando não se consegue obtê-la.

Outro ponto importante tocado, foi a dicotomia apresentada por essas mulheres entre o modo como elas disseram terem sido criadas pelos seus pais e a forma como veem a criação dos 
seus filhos. Ao mesmo tempo em que sentem orgulho de terem escolhido não conviver com seus excompanheiros, culpam-se por não tê-los na criação de seus filhos, tomando como referência a criação que tiveram, nos moldes de uma família nuclear e patriarcal. Há, dessa forma, um empoderamento da mulher que a leva a tomar decisões em prol de si mesma - sejam elas para evitar a violência do marido ou querer dormir um pouco mais após um dia cansativo de trabalho - que interferem na forma como a mulher deveria se comportar dentro do modelo de criação que tiveram de seus pais.

O peso desse modelo "tradicional" vem à tona quando o filho comete um ato infracional. Logo começam a se questionar o que fizeram de errado - dentro da concepção de que o erro do filho é culpa dela - e associam que a falha ocorreu devido à constituição errada de família que fizeram, ou seja, devido às "regalias" que elas proporcionaram a si mesmas os filhos não tiveram uma constituição familiar "ideal”, como àquela que elas tiveram de seus pais. Na insegurança de talvez não terem feito o melhor para o filho, quando optaram por constituir uma família que privilegiasse mais as suas escolhas pessoais - culpam-se novamente. 


\section{Capítulo VI}

Considerações

Embora discorrer sobre a produção de sentidos acerca do lugar do homem nas famílias de Campo Limpo abarque diversas dimensões, limitei-me a uma apresentação que considerei relevante para o desenvolvimento do objetivo proposto. Portanto, uma das tarefas mais difíceis, se não a mais, foi recortar as minhas vivências em partes que seriam relevantes para o nosso tema.

Durante o processo de construção do trabalho escolhi privilegiar o desenvolvimento dos casos e relatar densamente as peculiaridades de cada cena estabelecendo as relações possíveis, em detrimento de longas explanações sobre as teorias que envolvem o tema. Na medida do possível tentei indicar, no corpo do texto ou por meio de notas de rodapé, pontos para possíveis desenvolvimentos. Entendi que a riqueza do trabalho seria justamente trazer à baila o resultado de minha experiência no serviço.

Um aspecto fundamental para a construção do trabalho está relacionado com o meu posicionamento diante do tema. A pergunta: Onde está o pai?, é formulada por mim diante da situação em que estou enredado. Este questionamento foi rico em proporcionar uma maior abertura para pensarmos o lugar do homem nessas famílias. Todavia, uma leitura não atenta da dissertação pode levar ao risco de produzir em alguns leitores a sensação equivocada de que é necessário haver um pai na constituição familiar para um suposto desenvolvimento saudável de sua dinâmica. Não é necessário ter pai. No texto há passagens em que os próprios adolescentes e mães indagam-me o porquê de eu estar perguntando sobre a figura paterna, evidenciando que esse fato muitas vezes não se configura como um problema, ou mesmo, há ainda casos de famílias vivendo com esta ausência sem que isso ao menos venha a se tornar uma questão.

Seguindo o mesmo caminho, vimos que atrelar o ato infracional do adolescente à ausência paterna trata-se de uma concepção rasa no que se refere à multiplicidade de fatores que o envolve, principalmente os sociais e culturais.

$$
* * *
$$

Todas as famílias apresentadas nos casos possuem características matrifocais. A mãe como figura principal do grupo doméstico e exercendo grande influência sobre os demais. As mulheres 
decidem sobre as crianças e o funcionamento da casa, além da família ter a predominância de parentes do lado materno - matrilinear. Mulheres fortes, em uma situação em que os homens estão ausentes, possuem pouca influencia familiar e são pouco conhecidos. Diante disso, elas tomam à frente dos grupos familiares e se responsabilizam por todos, sobretudo pelos filhos, enquanto os homens se desresponsabilizam e/ou são desresponsabilizados das urgências familiares.

Mulheres fortes, que pagam um alto preço: para dar conta de suas jornadas duplas, triplas, elas aparentam ser mais velhas do que realmente são, estão sempre muito cansadas, física e emocionalmente extenuadas. Frequentemente, estão atravessadas pela sensação de que não estão dando conta de algo de que deveriam dar. Sensação, então, de falta e culpa - pelos problemas familiares, pelo cansaço, pela ausência do companheiro, pelo ato infracional cometido pelos filhos. Sensação que as fazem titubearem em suas decisões e desejarem uma volta a modelos conhecidos, tradicionais de família - quase que a qualquer custo.

Esse cenário, advindo dos casos discutidos, é permeado pelo aumento da participação das mulheres no mercado de trabalho formal e pelo benefício do Bolsa Família. Ambos possibilitaram uma maior autonomia financeira e maiores condições de escolher, desde como se vestir até como querem constituir suas famílias. E assim o fazem. Esse seria o início de uma emancipação? Falamos de uma "possível" emancipação feminina, pois, apesar desses recentes, e ainda incipientes ganhos, há também um acúmulo de funções e um inchaço de tarefas que as enredam, o que acaba, mais uma vez, aumentado as responsabilidades referente à elas - além dos consequentes desgastes.

Essa "nova" condição impacta muitas delas, principalmente quando seus filhos cometem o ato infracional. Apesar de expressarem contentamento diante de uma posição "emancipada", elas, usualmente, se responsabilizam por essa atitude do garoto, imaginando que por não terem um grupo familiar condizente com ideais "tradicionais" normativos de família - como a família nuclear ou o posicionamento condescendente em relação ao marido - são as culpadas pelas ações indesejadas dos filhos. Essa dicotomia entre o "novo" e o "tradicional", no que diz respeito ao posicionamento feminino diante da família, ressoa em muitas de suas ações provocando alegrias e tristezas.

Alegrias por terem a possibilidade de se colocarem como prioridade, realizando desejos pessoais e familiares. E tristezas por, em alguns momentos, estarem inseguras e duvidarem de que estão fazendo o correto, o melhor para os filhos e para ela.

Em um mundo que vem convocando cada vez mais as mulheres a uma emancipação - que mais se assemelha um inchaço de suas atribuições e tarefas - os homens parecem estar sem função. Perdidos. Assim como o pai do grupo de família, e o André. O único lugar familiar ainda um pouco 
mais reconhecido como deles é o de provedor. Parecem se agarrarem a essa função assim como Jorge, marido de Taís, se agarrava ao capacete de motoboy em meio às discussões femininas durante a visita familiar - ou como Carlos, reconhecido pela sua incansável disposição laboral em frente à casa - ou mesmo André, ao se apoiar em seu serviço para querer justificar seu caminho diário até a casa de sua ex-namorada para ver sua filha por alguns momentos.

Com a ausência paterna há toda uma renegociação de lugares e tarefas, de forma a dar conta das necessidades familiares. Mas, essa redivisão não é exata. As tarefas e valores que seriam historicamente associadas ao pai são redistribuídos de maneira peculiar. As mulheres são colocadas e também se colocam numa posição que provoca a inflação de suas tarefas, funções e cuidados, reorganizando a dinâmica familiar sem o homem. Isso se reflete não somente no pouco conhecimento sobre o homem/pai na família, mas também na pouca vontade de se falar dele, no pouco assunto, no pouco investimento, e por vezes, na pouca necessidade de se tê-lo por perto.

Pois, se os homens não estão, alguém há de estar. 


\section{Referências}

ARAÚJO, Sandra Maria Baccara (2005). A ausência da função paterna no contexto da violência juvenil. In: Simpósio Internacional do adolescente, São Paulo. Available from: $<$ http://www.proceedings.scielo.br/scielo.phpscript=sci_arttext\&pid=MSC00000000820050002000 06\&lng=en\&nrm=abn>. Acessado em: 07/02/2014.

BRASIL (2012). Sistema Nacional de Atendimento Socioeducativo. Lei n. 12.594 de 18 de janeiro de 2012. Brasília.

BRASIL (2010). PNAD - Primeiras análises: investigando a chefia feminina de família. In: Comunicados do Ipea, n. 65, Brasília.

BACELAR, Jefferson (1982). A Família da Prostituta. São Paulo: Ática.

BADINTER, Elisabeth (1986). Um é o outro; relações entre homens e mulheres. Rio de Janeiro: Nova Fronteira.

BARBOSA, Maria José Somedarte (1998). Chorar: verbo transitivo. In: Trajetórias de Gênero e masculinidades... Cadernos PAGU (11), Campinas: Núcleo de Estudos de Gênero/UNICAMP.

BERENSTEIN, Isidoro (1988). A Família e Doença Mental. São Paulo: Escuta.

BILAC, Elisabete (1978). Famílias de Trabalhadores: estratégias de sobrevivência. São Paulo: Símbolo.

BRUSCHINI, Cristina (2000). Mudanças e Persistências no Trabalho Feminino (Brasil, 1985 a 1995). In: SAMARA, Eni de Mesquita (org.), Trabalho Feminino e Cidadania, (CEDHAL/FFLCH/USP). São Paulo: Humanitas.

CASTELLS, Manuel (1999). A Era da Informação: economia, sociedade e cultura. São Paulo: Paz e Terra.

CHODOROW, Nancy (1990). Psicanálise da Maternidade: uma crítica a Freud a partir da mulher. Rio de Janeiro: Rosa dos tempos.

COUTO, Márica Thereza (2005). Estudos de famílias populares urbanas e a articulação com gênero. In: COUTO, Márcia Thereza \& SCOTT, Parry. (org.), Revista ANTHROPOLÓGICAS. Ano 9. Vol. 16 (1). Recife: Ed, Universitária da UFPE.

COVELO, Glaucya Hannah (2011). Imagens da paternidade: Indícios de lugares ocupados pelo pai na psique de homens e meninos na contemporaneidade. Dissertação de mestrado, Instituto de Psicologia, Universidade de São Paulo, São Paulo.

DA MATTA, Roberto (1985). A casa e a rua: espaço, cidadania, mulher e morte no Brasil. São Paulo: Brasiliense.

DEL PRIORE, Mary (1993). Ao Sul do Corpo: condição feminina, maternidade e mentalidade no Brasil Colônia. Brasília: EDUNB. 
DIAS, Maria Odila Leite da Silva (1984). Quotidiano e poder em São Paulo no século XIX. São Paulo: Brasiliense.

EIGUER, Alberto (1985). Um Divã para a Família. Porto Alegre: Artmed.

FAUSTO NETO, Ana Maria (1982). Família operária e reprodução da força de trabalho. Petrópolis: Vozes.

FONSECA, Cláudia (2004). Família, Fofoca e honra: etnografia de relações de gênero e violência em grupos familiares. $2^{\mathrm{a}}$ edição. Porto Alegre: Editora da UFRGS.

FORTES, Meyer (1958). Introdution. In: GOODY, Jack. (ed.), The Developmental Cycle of Domestic Groups. Cambridge: Cambridge University Press.

FREUD, Sigmund (1917 [1915]). Luto e Melancolia. In: Obras Completas de Sigmund Freud. V.14. Rio de Janeiro: Imago.

(1996 [1921]). Psicologia de Grupo e Análise do Ego. In: Obras Completas de Sigmund Freud. V.18. Rio de Janeiro: Imago.

(1924). A dissolução do complexo de Édipo. In: Obras Completas de Sigmund Freud.

V. 19. Rio de Janeiro: Imago.

Janeiro: Imago.

(1931). Sexualidade Feminina. In: Obras Completas de Sigmund Freud. V. 21. Rio de

FREYRE, Gilberto (2004 [1933]). Casa-Grande \& Senzala: formação da família brasileira sob o regime da economia patriarcal. $49^{\mathrm{a}}$ edição. São Paulo: Global.

GOLDENBERG, Gita Wladimirski (1998). O pai simbólico está ausente na criança e no adolescente infratores. In: LEVISKY, David Léo. Adolescência pelos caminhos da violência - a psicanálise na prática social. São Paulo: Casa do Psicólogo.

KLEIN, Melanie (1946). Notas sobre alguns mecanismos esquizóides. In: KLEIN, M. Obras Completas de Melanie Klein. Buenos Aires: Paidós.

MANDELBAUM, Belinda (2010). Psicanálise da Família. São Paulo: Casa do Psicólogo.

MARCílIO, Maria Luiza (1974). A Cidade de São Paulo: povoamento e população (1750-1850). São Paulo: Pioneira/EDUSP. (1986). Caiçara, terra e população. São Paulo: Paulinas/CEDHAL.

MELLO, Sylvia Leser (2002). Classes Populares, Família e Preconceito. In: Psicologia-USP. vol. 3, n.1/2. São Paulo: EDUSP.

MENESES, D.M.A \& BRASIL, K.C.T. (1998). Dimensões psíquicas e sociais da criança e do adolescente em situação de rua. In Psicologia: Reflexão e Crítica, N. 2, V. 11, Porto Alegre. 
NEGREIROS, Teresa C. G.M. \& FEREZ-CARNEIRO, Terezinha (2004). Masculino e Feminino na família contemporânea. In: Estudos e Pesquisa em Psicologia. Ano 4. N. 1. Rio de Janeiro: UERJ.

NEVES, Delma Pessanha (1985). Nesse terreiro galo não canta: estudo do caráter matrifocal de unidades familiares de baixa renda. Anuário Antropológico, 1983. Rio de Janeiro/Fortaleza: Tempo Brasileiro/UFC.

OGANDO, Ana Carolina F. L. (2010). Entre o Público e Privado: as relações de Gênero no Pensamento Positivista e Católico (1870-1889). Apresentado no 9 encontro Fazendo Gênero Diásporas, Diversidades, Deslocamentos, Florianópolis, 23 a 26 de agosto de 2010.

PRADO JR, Caio (1977). Formação do Brasil contemporâneo. Colônia. São Paulo: Brasiliense.

PUGET, Janine (2001). Disso não se fala... Transmissão e Memória. In: RUIZ CORREA, Olga, (org), Os avatares da transmissão psíquica geracional. São Paulo: Escuta.

QUINTAS, Fátima (1986). Sexo e marginalidade: um estudo sobre a sexualidade feminina em camadas de baixa renda. Petrópolis: Vozes.

REGO, Walquiria Leão \& PINZANI, Alessandro (2013). Vozes do Bolsa Família: autonomia, dinheiro e cidadania. São Paulo: UNESP.

RUIZ CORREA, Olga B. (2000). O legado familiar: a tecelagem grupal da transmissão psíquica. Rio de Janeiro: Contra Capa Livraria.

SAMARA, Eni de Mesquita (1989). As mulheres, o poder e a família. São Paulo: Marco Zero e Secretaria de Estado da Cultura de São Paulo.

. (1999). Família e vida doméstica no Brasil: dos engenhos aos cafezais. Estudos CEDHAL n. 10. São Paulo: Humanitas.

Brasiliense. (2004 [1983]). A família brasileira. 4 edição. Coleção tudo é história: 71. São Paulo:

SAMARA, Eni de Mesquita \& MATOS, Maria Izilda Santos (2000). Cotidiano e Trabalho Feminino (1890-1940). In: SAMARA, Eni de Mesquita (org.), Trabalho Feminino e Cidadania, (CEDHAL/FFLCH/USP). São Paulo: Humanitas.

SALEM, Tania (1980). O Velho e o Novo: Um estudo de papéis e conflitos familiares. Petrópolis: Vozes.

SARTI, Cynthia (2007 [1996]). A família como espelho: um estudo sobre a moral dos pobres. 4 edição. São Paulo: Cortez.

SCOTT, Parry (1990). O Homem na Matrifocalidade: gênero, percepção e experiências do domínio doméstico. N. 73, p.38-47. São Paulo: Cadernos de Pesquisa.

Secretaria de Segurança Pública. http://www.ssp.sp.gov.br/estatistica/porRegiao.aspx?cod=1

Secretaria municipal de Assistência e Desenvolvimento Social. 
http://www.prefeitura.sp.gov.br/cidade/secretarias/assistencia_social/observatorio_social/mapas.

SMITH, Raymond T. (1956). The negro family in British Guiana. London: Routledge \& Kegan Paul.

. (1973). The matrifocal family. In: GOODY, Jack, The character of kinship. Cambridge: Cambridge Univ. Press.

SPINK, Peter K. (2003). Pesquisa de Campo em Psicologia Social: uma Perspectiva Pósconstrucionista. Texto organizado por Spink e membros do Núcleo de Organização e Ação Social. Programa de Pós- graduação em Psicologia Social da Puc-SP.

TEIXEIRA, Paulo Eduardo (2004). O outro lado da família brasileira. Campinas: Editora da Unicamp.

WATARAI, Felipe \& ROMANELLI, Geraldo (2005). Trabalho e identidade de adolescentes do sexo masculino de camadas populares. In Proceedings of the 1th Simpósio Internacional do Adolescente, 2005, São Paulo (SP) [online]. 2005 [cited 30 January 2014]. Disponível em: $<$ http://www.proceedings.scielo.br/scielo.phpscript=sci_arttext\&pid=MSC00000000820050002000 $89 \& \operatorname{lng}=$ en\&nrm=iso $>$.

WOORTMANN, Klaas (1987). A Família das mulheres. Rio de Janeiro: Tempo Brasileiro.

WOORTMANN \& WOORTMANN, Klass e Ellen (2004). Monoparentalidade e Chefia Feminina. Conceitos, Contextos e Circunstâncias. Brasília: Série Antropologia-DF.

Www.mds.gov.br/bolsafamilia. Acessado em 12/02/2014.

ZALUAR, Alba (1994 [1985]). A Máquina e a Revolta - as organizações populares e o significado da pobreza. 2 edição. São Paulo: Editora Brasiliense. 


\section{Anexo}

\section{Perguntas norteadoras do Grupo de Família}

- Primeiro, conte-me como é a composição familiar de cada um de vocês.

- Porque que vocês acham que têm mais mulheres presentes do que homens aqui?

- Quais são as atribuições de homem/mulher dentro e fora de casa? Como eram quando vocês eram pequenos? Mudou? Como?

- Você acha que a mulher tem mais espaço, mais liberdade do que antes? Como você vê isso no seu cotidiano? Conte um exemplo.

- E o homem? Tem mais espaço/liberdade que antes, faz mais coisas do que fazia antes? Conte um exemplo.

- Porque que vocês acham que essa mudança na posição de homem e mulher tá acontecendo? (Ou não aconteceu?).

- Como o homem participa na família? E você, o que faz?

- (Para aqueles que não tem o companheiro) O que de mais importante você acha que o companheiro(a) poderia contribuir com a família se estivesse em casa? 